DOI: $10.11649 /$ abs.2017.007

\title{
Joanna Gierowska-Katłaur
}

Instytut Historii Polskiej Akademii Nauk

Warszawa

j.gierowska-kallaur@uw.edu.pl

\section{Stanisław Bułak-Bałachowicz. Postać, która mogła połączyć narody byłego Wielkiego Księstwa Litewskiego, a jednak ich nie połączyła}

\section{O Bułak-Bałachowiczu prywatnie}

Stanisław Bułak-Bałachowicz - wnuk Sylwestra Bałachowicza i Michaliny Jasińskiej, a syn Nikodema i Józefy z Szafranów - znał języki: polski, rosyjski, niemiecki, litewski i białoruski. Urodzony 10 lutego 1883 r. w wiosce niedaleko miasta Meyszty Widze (obecnie rejon Witebsk), według informacji rodziny ze związku kucharza i pokojówki w majątku Meysztowiczów w Meysztach, był polskojęzycznym katolikiem. Zgodnie z zapisami послужного списка, Bułak-Bałachowicz miał pochodzić z kowieńskiej prowincji chłopów. Jego ojciec pochodził w rzeczywistości ze zubożałej rodziny szlacheckiej. Według informacji samego Bułak-Bałachowicza rodzic sprzedał na cztery lata przed jego urodzeniem nabyty po ożenku majątek Judycyny k. Szarkowszczyny i wydzierżawił majątek Stokopiejewo w Brasławszczyźnie. Wiarygodne informacje biograficzne do końca okresu służby w Armii Carskiej podają Zbigniew Karpus i Oleg Łatyszonek (Karpus \& Łatyszonek, 1995, ss. 160-169). Okres estoński opisał Tomasz Paluszyński (2006, ss. 81-99). Informacje o generale uzyskane od rodziny wyczerpująco omówił Marek Cabanowski (1993, s. 7 i dalsze, 2013, s. 5 i dalsze). 

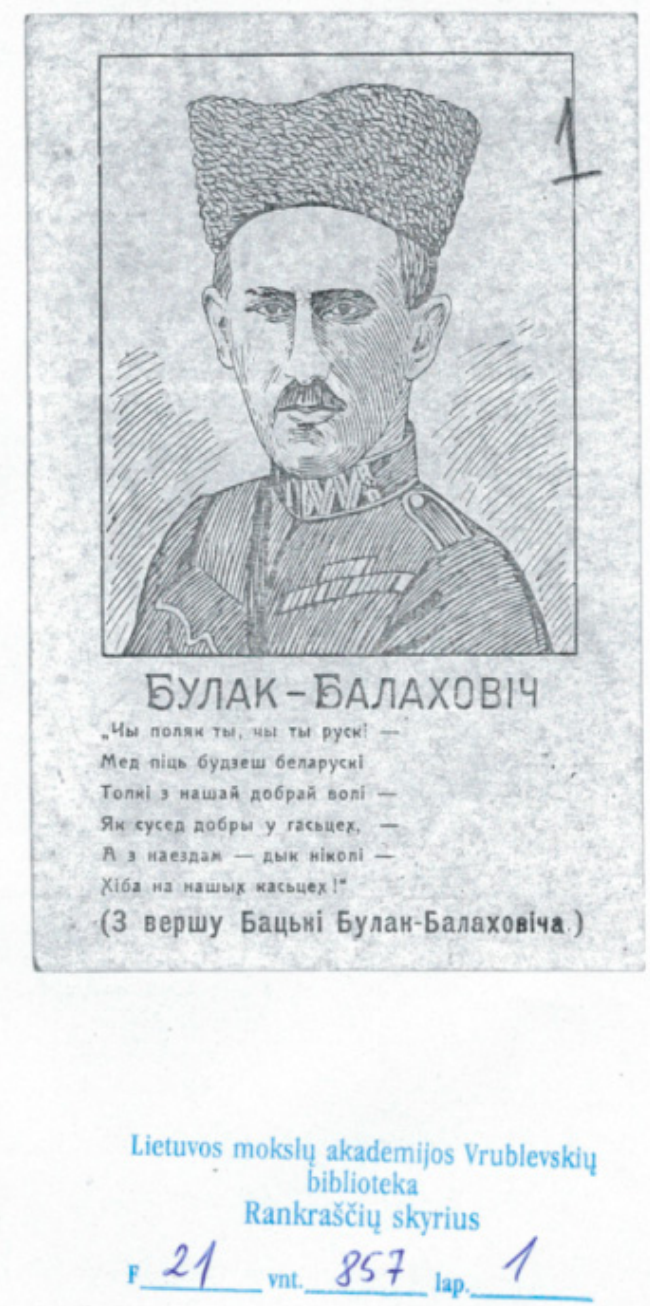

Ryc. 1. Druk ulotny z epoki. Źródło: Lietuvos mokslų akademijos Vrublevskių biblioteka. Rankraščių skyrius (LMAB), Fond 21, teczka 857, k. 1

Stanisław miał liczne rodzeństwo, z którym był blisko związany: dwóch braci Mieczysława (służył w Mandżurii) i Józefa oraz sześć sióstr: Marię (zamężną z Czerwińskim), Paulinę (zamężną z Józefem Ejsmontem), Weronikę (zamężną z Rudzińskim), Ludwikę (zamężną z Gruzinem Franżułło), Stefanię (zamężną primo voto z Orszulikiem vel Stefańskim, secundo voto $z$ Jarmolińskim) i Leonę (zamężną z Janem Orszolakiem[?]). Z rodzeństwem pozostawał do końca życia w bliskich kontaktach. 
W sumie bolszewicy zabili czternaście osób z najbliższej rodziny Bałachowicza: szwagra Józefa Ejsmonta bestialsko zamordowanego w Święcianach, szwagra Jana Orszolaka, oficera austriackiego rozstrzelanego w Moskwie, szwagra Franżułło rozstrzelanego w Tyfilisie. W wyniku prześladowań zmarli matka i szwagier Rudziński, zaginęli Ludwika Franżułłowa i jej synkowie (jedno z dzieci na pewno zmarło), brat Józef zginął w zamachu, a ojciec zmarł ze zgryzoty po śmierci Józefa i zmasowanej akcji niechęci skierowanej pod adresem Stanisława [CAW, sygn. I.480.72, k. 170-171].

Z kolei brat Stanisława, Józef, poślubił Zinaidę Punin, z którą miał dwoje dzieci Zdzisława i Gabrielę.

Obaj bracia - Stanisław i Józef, udzielali w potrzebie pomocy siostrom. Jednorazowo - Ludwice Franżułłowej z synami, po których niebawem ślad zaginął - po zabójstwie szwagra. Systematycznie wspierali zaś Paulinę Ejsmontową i Weronikę Rudzińską (z ośmiorgiem dzieci), gdyż nie otrzymywały one zaopatrzenia wdowiego po mężach zabitych w walce przez bolszewików. Niesłusznie oskarżony o szpiegostwo siostrzan [siostrzeniec] Czerwiński, syn Marii, prowadził w latach 30. XX w. Biuro Interesów Generała.

Według już opublikowanego, własną ręką spisanego życiorysu (Karpus \& Łatyszonek, 1995, ss. 160-169) Stanisław Bułak-Bałachowicz nauki pobierał kolejno w szkole powiatowej w Nowoaleksandrowsku w Kowieńszczyźnie i w polskim gimnazjum św. Stanisława w Petersburgu, gdzie pozostawał pod opieką krewnego matki, księdza Ksawerego Jasińskiego. Wbrew woli rodziców nie kształcił się jednak na duchownego, lecz odbył czteroletni kurs praktyczno-agronomiczny w dobrach Belmont hrabiego Broel-Platera na Wileńszczyźnie. Od 1902 r. sam się utrzymywał. Od 1903 r. zatrudniony był $\mathrm{w}$ charakterze buchaltera-płatnika przy budowie kolei na terenie ziemi nowogródzkiej. Zimę w roku 1903/1904 spędził na Kaukazie w gościnie u siostry Marii i szwagra Czerwińskiego zawiadującego tam składami kolejowymi. Od wiosny 1904 r. do rozpoczęcia I wojny światowej pełnił funkcję plenipotenta dóbr Zyberk-Platerów w Horodźcu Łużkach w Dziśnieńszczyźnie. W 1905 r. ożenił się z córką tamtejszego lekarza Henryką Gabrielle, małżeństwo trwało 8 lat, trzykrotnie został ojcem w roku 1907 (córka Aldona), 1910 (syn Medard), 1911 (syn Henryk). W 1915 r. zmarła jego żona, z którą przez ostatnie lata jej życia pozostawał w separacji. Drugą żoną Stanisława Bułak-Bałachowicza była Herta von Gerhardt, z którą miał dwie córki - Zofię i Marię. Jego trzecią żoną była Janina Korecka (córka Jana Koreckiego), która urodziła mu również dwie córki, Danutę i Barbarę, ale małżeństwo to nie trwało długo. W 1929 r. Bułak-Bałachowicz podpisał papiery rozwodowe, a żona - $\mathrm{z}$ braku środków do życia w Polsce wyjechała do rodziny do Finlandii [CAW, sygn. I.480.72, k. 66-66v-67-67v-68]. Do rozwodu niewątpliwie przyczynił się fakt, iż majątek odziedziczony przez nią po zmarłym w Stanach ojcu (ziemię i 5000 \$) generał przeznaczył na spłatę kredy tów zaciągniętych na uruchomienie po zakończeniu działań wojennych warsztatów leśnych w Białowieży, pozwalających na fizyczne przetrwanie jego żołnierzom i jemu samemu. 
Sytuacja materialna Bułak-Bałachowicza po wojnie była bardzo nieciekawa. Z papierów przechowywanych w Centralnym Archiwum Wojskowym (dalej CAW) w teczce Bułak-Bałachowicza (Kolekcja Generałów i Osobistości) wynika, że Skarb Państwa do roku 1930 nie zwrócił ani Bałachowcom, ani samemu Bałachowiczowi nawet $1 / 3$ majętności, którą ci mieli przywieźć ze sobą w marcu $1920 \mathrm{r}$. jako łup wojenny jeszcze $\mathrm{z}$ Łotwy. W celu otwarcia wspomnianych warsztatów generał zmuszony był do wystawienia weksli na swoje nazwisko. Jak wynika z relacji Bałachowicza, przechowywanej w CAW, uruchomione przez niego przedsiębiorstwo upadło na skutek decyzji Rządu Polskiego (1924) o sprzedaży wyłącznego prawa do eksploatacji Puszczy Białowieskiej brytyjskiej firmie „The Century European Timber Corporation”. Spółka, dzięki umowie z Rządem Polskim, uzyskała dziesięcioletnią wyłączność (od 1924 do 1934 r.) na użytkowanie tego obszaru leśnego (Korbel, 2012).

Firma „The Century European Timber Corporation” (dalej „Centura”) dążyła do obniżania zarobków, pozbawiając pracowników ubezpieczenia. Prowadziła rabunkową gospodarkę leśną, masowo wycinano jakościowo najcenniejsze drzewa. Według ustaleń Korbela „Centura” dostała koncesję na wyrąb 7,2 $\mathrm{mln}^{3}$ drewna nad Niemnem i w Puszczy Białowieskiej, w tym $\mathrm{z}$ samej puszczy $4 \mathrm{mln} \mathrm{m}^{3}$. Zasoby drzewostanu po 10 latach miały spaść do $17 \mathrm{mln} \mathrm{m}^{3}$, czyli dwukrotnie zmniejszyć się w stosunku do 1916 r. Ostatecznie wywieziono ponad 2,5 miliona metrów sześciennych drewna, nie nasadzając $w$ to miejsce nowych drzew. Ta rabunkowa gospodarka doprowadziła do dewastacji drzewostanu. Odpowiedzialnym za ten stan rzeczy był Anglik, niejaki Bell. Sytuacji nie poprawiał fakt nieoczyszczania zrębów z gałęzi i drewna słabszej jakości. Na potrzeby administracji wyremontowano pałac carski a kierownikami dwóch z działów zostali dwaj rosyjscy książęta. W 1928 r. na hajnówkowskich kolejkach leśnych firmy „Centura" rozpoczął się dwumiesięczny powszechny strajk. Według ustaleń Korbela akcja strajkowa zakończyła się uzyskaniem podwyżki płac od 5 do 20\% (Korbel, 2012).

Wskutek starań generała zatrudniono go tam jako inspektora pracy. Nie był to ze strony Brytyjczyków akt filantropii. Borykali się z deficytem pracowników leśnych. Bałachowicz zaś choć w ten sposób chciał zapewnić utrzymanie swoim oddziałom (nieco ponad 2000 osób) pracującym dotąd na własny rachunek przy porządkowaniu puszczy z suszu i na skutek fatalnej decyzji rządu pozbawionych środków do życia.

Od tego też czasu Bułak-Bałachowicz oprócz narastających kłopotów finansowych (konfiskowano mu wszelkie honoraria autorskie na poczet wykupu długów) dodatkowo borykał się z publicznymi skargami ludzi historykom zupełnie nieznanych, a raczej znanych wyłącznie z pomówień generała o czyny, do których się nie poczuwał, ludzi obciążających generała miałkimi zarzutami, czy to o płatną protekcję w przeniesieniu służbowym do pułku w Warszawie, czy to o niezapłacenie rachunku za jakąś taksówkę, czy też o to, że ludzie powołujący się na znajomość z generałem 
Bałachowiczem zaprosili jakąś pannę do lokalu pozostającego w dyspozycji generała, upili ją i pozostawili na mieście etc. etc. [CAW, sygn. I.480.72, k. 7-8, k. 26-36].

Generał nie tylko borykał się z problemami finansowymi, ale również był dodatkowo przekonany, iż jest nękany wskutek zaplanowanej akcji wyrzuconego przez niego ze Związku Bałachowców Władysława Rogowca i jego kolegów, których wręcz podejrzewał o powiązania $\mathrm{z}$ wywiadem sowieckim [CAW, sygn. I.480.72, k. 49-51] (jeden z wyrzuconych istotnie został po kilku latach powieszony za szpiegostwo). Z listu Bułak-Bałachowicza do posła Walewskiego wynika, że Bułak-Bałachowicz wygrał sprawy w sądach. Ponadto Bułak-Bałachowicz prosił o „łaskawe rozpatrzenie wszystkich skarg obrońców kresów wschodnich, rozpowszechnianych przez ich prezesa Optałowicza oraz Władysława Rogowca, pracującego obecnie w charakterze likwidatora spraw Związku”, który „nieprawnie archiwum przeniósł do lokalu Kresów Wschodnich tj. do Związku, gdzie jest utworzona kuźnia wszelkich oszczerstw i plotek, i gdzie pracują ludzie w swoim czasie przez mnie zdemaskowani i wyrzuceni ze Związku. Władysław Rogowiec w r. ub. [1932] oskarżył mego sekretarza Czarnuszewicza o szpiegostwo, a mnie o popieranie tej akcji i tolerowanie różnych machinacji w biurze" [Bułak-Bałachowicz pisze obszernie, iż Rogowiec odwołał oskarżenia w sądzie a Czarnuszewicza listownie przeprosił] „to dzisiaj dalej [Rogowiec] prowadzi akcję, oskarżając o rzekome nadużycia finansowe na szkodę Związku [--] akcja oszczercza prowadzona takimi samymi metodami, jak Jan Bakowski wydalony przez mnie w 1929 ze Związku, a powieszony za szpiegostwo dopiero w 1932. Rogowiec używa tych samych metod - tamten oskarżał moich bliskich o szpiegostwo - a sam był szpiegiem, oskarżał również Rogowiec moich bliskich [--] jest to człowiek pozbawiony wszelkich skrupułów i etyki” [CAW, sygn. I.480.72, k. 49-51]. W dalszej części obszernego listu Stanisław Bułak-Bałachowicz twierdził, iż wszystkie skargi Optałowicza, Godlewskich, Malinowskich i „wielu innych” wysuwane są z inspiracji Rogowca [CAW, sygn. I.480.72, k. 49-51].

Ku wielkiemu rozgoryczeniu Bułak-Bałachowicza ci ludzie, z których „oczyścił” szeregi swojej organizacji, byli, w jego opinii, wręcz hołubieni przez establishment pomajowy.

Gdy Bułak-Bałachowicz miał pod pięćdziesiątkę był mężczyzną samotnym, stracił syna Medarda i jedną z córek (z trzeciego małżeństwa). Syn Henryk, ppor. 17 Pułku Ułanów doznawał w swej jednostce nieprzyjemności ze strony kolegów ze względu na przeszłość swego ojca.

W liście z grudnia 1929 r. skierowanym do płk. Rudolfa (brak pierwszej strony rękopisu, lecz zaopatrzony w daty wysłania spis zawartości teki z listami wskazuje jednoznacznie na tego adresata), daje wyraz swemu głębokiemu przekonaniu, iż usunięci przez niego „łże-bałachowcy” spleceni byli siecią intryg gospodarczych z wysokimi urzędnikami administracji wojskowej [CAW, sygn. I.480.72, k. 21-23]. W kwietniu 1931 r. odrzucono wniosek Zarządu Głównego „Kapituły Krzyża Wołynia” z Łucka o nadanie generałowi „Krzyża Wołynia”. Czarę goryczy Bałachowicza przelało jednak oskarżenie go o zdefraudowanie pieniędzy społecznych. 
Prawdę powiedziawszy - sam sobie był winien. Bez kontroli wydawał weksle na pokrycie kosztów rozmaitych imprez narodowych, a w archiwum Związku Obrońców Ojczyzny (przejętym przez jego osobistego wroga - Władysława Rogowca) znajdowały się czyste karty z podpisem generała in blanco. Dyskomfort sytuacji, w której się znalazł, sprawił, że w latach poprzedzających wybuch II wojny światowej generał rozważał nawet wyjazd z Polski „za chlebem” do Kalifornii [CAW, sygn. I.480.72, k. 66-66v-67-67v-68].

Jego plany znane były prasie. W „Naszym Przeglądzie” z 7 stycznia 1934 r. czytamy: „Koniec kariery Gen. Bałachowicza. Istniejący w Warszawie od r. 1920 "Związek byłych powstańców narodowych", zorganizowany przez sławetnego gen. Bułak-Bałachowicza, został przed dwoma laty zakwalifikowany przez władze do likwidacji z powodu niewłaściwej działalności zarządu. Komisja likwidacyjna nie spieszyła się jednak z rozwiązaniem związku. Wobec tego komisarz rządu rozwiązał Komisję Likwidacyjną i wyznaczył likwidatora w osobie inż. Rogowca. Jak się dowiadujemy, gen. Bałachowicz opuści wkrótce Polskę" [CAW, sygn. I.480.72, k. 4].

\section{O Bułak-Bałachowiczu jako o osobie publicznej}

Zaledwie dwudziestojednoletni Stanisław zarządzał słynną stadniną Zyberk-Platerów, a w wieku lat dwudziestu dwóch, jako członek partii zbliżonej do SR pełnił funkcję sędziego rewolucyjnego w sporach między chłopami a ziemianami. Był osobą powszechnie znaną w okolicy, darzoną szacunkiem i poważaniem. Doceniano jego zaangażowanie $\mathrm{w}$ życie lokalnej społeczności - Bałachowicz był organizatorem i naczelnikiem Ochotniczej Straży Pożarnej w Łużkach. W okresie późniejszym nadal często działał też jako arbiter w sporach między chłopami a ziemianami. Uważany był za mediatora skutecznego i sprawiedliwego - pozyskał sobie wówczas, towarzyszący mu już przez całe życie, przydomek „Baćka” (Cabanowski, 1993, 2000, 2013 i inni).

$\mathrm{Z}$ upływem czasu sława jego imienia zataczała coraz szersze kręgi. W 1908 r. osobiście pojmał grasującego od Kaukazu do Bałtyku przywódcę bandy rzezimieszków, bandytę Ciastę. Od tamtej pory Bałachowicz zyskał sobie jeszcze drugi przydomek „Bułak” (tzn. „kto ma wiatr”), w pełni odzwierciedlający dominującą cechę jego usposobienia i charakteru. Ludzie mu podobni lgnęli do niego.

Pokolenie Bułak-Bałachowicza wychowane było w myśl powszechnie panującej zasady „Ku wojnie wychowany ma być mąż, niewiasta zaś ku wytchnieniu wojownika" (Friedrich Nietzsche). By wziąć udział w rozpoczynającej się Wielkiej Wojnie mieszkańcy ziem pod zaborem rosyjskim mieli tylko jedną drogę.

W początkach Wielkiej Wojny w reakcji na odezwę Wielkiego Księcia Mikołaja Mikołajewicza z sierpnia 1914 r. na czele grupy Polaków z Dziśnieńszczyzny własnym sumptem wyposażonych w konie i broń, Bułak-Bałachowicz wstąpił jako ochotnik do 2 Lejb-Ułańskiego Pułku Kurlandzkiego w randze chorążego armii carskiej. Sformował szwadron kawalerii, z którym walczył pod Sochaczewem. Służył m.in. pod komendą 
„старшины” G. M. Semenowa (przyszłego dowódcy wojska kozackiego), a od 5 września 1915 r. dowodził szwadronem partyzantów z 2 Dywizji Kawaleryjskiej. Na froncie pod Rygą wszedł w skład oddziału partyzanckiego atamana Leonida Punina, a od marca 1916 r. został mianowany dowódcą 500-osobowego szwadronu do zadań specjalnych, składającego się z plutonu kozaków, huzarów, ułanów i dragonów. Dokonywał ze swoim ludźmi cudów waleczności, grasując na tyłach nieprzyjaciela i siejąc prawdziwy postrach. W sumie był pięciokrotnie ranny. W uznaniu zasług na polu walki, waleczności i imponujących forteli w trakcie działań bojowych został awansowany do rangi oficerskiej i uzyskał szereg odznaczeń (Medal św. Jerzego, trzy Krzyże św. Jerzego 4., 3. i 2. stopnia - dwa srebrne i jeden złoty, Medal św. Anny za odwagę, Krzyż Francuski z Palmą oraz liczne pochwały, awanse i nagrody). Przed rewolucją został wybrany dowódcą pułku i awansował (1916-1917) do rangi sztabs-kapitana.

W początkach 1918 r. (w lutym) przeszedł do Armii Czerwonej. Kierowały nim również pobudki osobiste. Rodzony młodszy brat Stanisława - Józef służył jako dowódca niewygodnego dla bolszewików 1 Szwadronu Polskiego, oddziału rotmistrza Leona Przesieckiego. Niesprzyjający stosunek dowództwa sprawiał, iż los podwładnych Józefa (i jego samego) był co najmniej niewiadomą. Stanisław zapisał się w powszechnej pamięci jako realizator akcji ratunkowej, mającej na celu ocalenie ludzi z tej jednostki. Sprzyjało mu szczęście. Oprócz zgody na tworzenie nowego oddziału polskiego Stanisław Bułak-Bałachowicz miał nawet uzyskać od Trockiego niespodziewaną propozycję objęcia funkcji inspektora Czerwonej Kawalerii. Oferty tej nie przyjął. Zagrożony represjami z całym pułkiem przebił się do Pskowa na stronę Białej Armii (24 listopada 1918 r.), gdzie zaczął tworzyć kadry Armii Północnej. Ponieważ nie został w Pskowie powitany z otwartymi rękoma przez sponsorów tej armii (Niemców), rozbroił ich, następnie rozgromił tyły bolszewików i przedarł się do Estonii. Kontynuował służbę w mieście Werro (obecnie Wyru) w Armii Estońskiej. Za zasługi w obronie Estonii został awansowany do rangi podpułkownika. W lutym 1919 r., w chwili utworzenia Korpusu Północnego pod dowództwem generała A. P. Rodzianko, dołączył do niego ze swoim oddziałem. Bułak-Bałachowicz dokonał serii zwieńczonych sukcesem napadów na radzieckie punkty oporu (пункты опорные), w tym na bazę Czudskiej Floty - Raskopieł i Gdów (28 lutego 1919 r.). W chwili powstania Armii Północno-Zachodniej Mikołaja Judenicza Bułak-Bałachowicz został jego podkomendnym. Przy wiosennej ofensywie Korpusu Północno-Zachodniego (tak zmienił nazwę Korpus Północny) w maju 1919 r. oddział Bułak-Bałachowicza ponownie zdobył Gdów, odrzucając wojska sowieckie na północ, a Bułak-Bałachowicz awansowany został do stopnia pełnego pułkownika. Po zdobyciu Pskowa 25 maja 1919 r. przez wojska estońskie, Bułak-Bałachowicz został wyznaczony (30 maja 1919 r.) na komendanta tego miasta (Клавинг, 2003). Jego legenda zataczała już tak szerokie kręgi, iż jego rosyjscy konkurenci militarni zaczęli ją niszczyć. Niewykonalnym było podważenie jego militarnego talentu, zaczęto więc tego człowieka oczerniać. 
Historiografia rosyjska do dziś lansuje tezę o bardzo niekorzystnym pokłosiu działalności Stanisława Bułak-Bałachowicza na stanowisku komendanta Pskowa. Psków, według historyków rosyjskich, miał być w czasie jego zarządzania całkowicie rozgrabiony, a ludność miasta - poddana terrorowi. Dlatego właśnie, w celu spacyfikowania niesfornego „Baćki” zapaść miała decyzja o podporządkowaniu jego oddziału 2 Korpusowi Sił Regularnych pod dowództwem E. K. Arseniewa. Jednak tego rozkazu Bułak-Bałachowicz miał nie usłuchać, więcej - rozpoczął starania o przemianowanie jego oddziału na „Armię Ludową” (czy nie brzmi to jak „Armia Terytorialna” inaczej „Krajowa”?). Konflikt trwał ponad miesiąc. Dowódca Armii Północno-Zachodniej, generał Judenicz postanowił przeciąć przesilenie i wezwał Bałachowicza (22 sierpnia 1919 r.) do karnego raportu, do którego ten, nie w ciemię bity, nie stawił się. Według rosyjskiego historyka - Walerego Klawinga Bułak-Bałachowicz najpierw walczył w szeregach 2 Estońskiej Dywizji z siedzibą w Pskowie nad rzeką Wielką, następnie udał się do Rewla pod komendę - jak z przekąsem określa Klawing - „swego dobroczyńcy" - generała Laidoniera. Generał Judenicz 24 sierpnia 1919 r. wydał więc rozkaz, który mówił: „generał Bułak-Bałachowicz jest usunięty z armii i jest uważany za dezertera" (Клавинг, 2003; Кручинин, 2011 i inni).

Historiografia polska (Cabanowski, 1993, 2000, 2013), a przede wszystkim polskie relacje i odnalezione polskojęzyczne źródła, przedstawiają ten problem inaczej. Również zachowane zdjęcia filmowe z Pskowa tego czasu nie dają podstaw do obciążania Bułak-Bałachowicza zarzutami sformułowanymi przez Walerego Klawinga (Isakau, 2009). Jako dowódca grupy wypadowej Bułak-Bałachowicz opanował Psków i zaczął tam organizować normalne życie (z demokratycznymi wyborami do rady miejskiej i wydawaniem prasy codziennej włącznie). Decyzja Judenicza o oddaniu Pskowa bolszewikom wywołała w Bałachowiczu silne emocje. Kontakty z Estończykami i demokratyczne poglądy Bułak-Bałachowicza, których nigdy nie ukrywał, a może w jeszcze większym stopniu dążenie „Baćki” do zaprowadzania wokół siebie „ładu i sprawiedliwości" na własną rękę sprawiły, iż Judenicz postanowił aresztować niewygodnego pułkownika. Ten, pozostawiwszy dowództwo bratu, uciekł i sformował odnoszące liczne sukcesy oddziały z „zielonej gwardii” grasujące na tyłach bolszewickich (dla mnie znów były to oddziały „Armii Terytorialnej” inaczej „Krajowej”).

\section{O żołnierzach Bałachowicza}

O swoistej elicie trzonu mieszkańców byłego Wielkiego Księstwa Litewskiego (intarsjowanej rzucającymi się w oczy ludźmi stricte egzotycznymi), czyli o Bałachowcach tak w dwudziestoleciu pisał Stanisław Lis-Błoński: „Język Grupy Bałachowicza stanowił taki sam konglomerat, jak i typy ludzkie. Słyszałem rozmowy prowadzone po rosyjsku, po żydowsku, gdzieniegdzie po polsku. Całe to różnobarwne towarzystwo tworzyło grupki” (Lis-Błoński, 2013, s. 26) [---] „nie było języka na kuli ziemskiej, który byłby obcy dla ludzi tej Grupy. Japoński, tatarski, mongolski, angielski, włoski 
czy urugwajski - nie przedstawiały dla nich trudności, zawsze się znalazł jakiśs "graf" lub »kniaź« który nie jednym, to drugim lub dziesiątym językiem władał” (Lis-Błoński, 2013, ss. 90-91). „Żołnierze armii Bałachowicza rozmawiali z sobą po rosyjsku, gdyż w większości wypadków był to ich rodzinny język" (Lis-Błoński, 2013, s. 61). [Uwaga! - dla Błońskiego posługiwanie się językiem rosyjskim najwyraźniej było równoznaczne z byciem Rosjaninem]. „Egzotyczność i odrębny sposób organizacji tego walecznego oddziału budziły zaciekawienie” (Lis-Błoński, 2013, s. 45), „[byli to] watażkowie z całego świata, ludzie z bogatą przeszłością, lecz bez przyszłości i bez Ojczyzny” (Lis-Błoński, 2013, s. 35), „wojsko, jakiego dotąd nie widziałem. Zupełnie inne niż nasze, inne niż rosyjskie czy niemieckie. Niepodobne do żadnego [--] $\mathrm{z}$ braku odpowiedniej ilości mundurów każdy chodził w czym miał, a wszystko to razem tworzyło barwną, egzotyczną mozaikę. Wrażenie zupełnie odrębnego wojska potęgowała jeszcze różnorodność typów fizycznych, poczynając od rasowych typów Kaukazu, poprzez azjatyckie typy Tatarów, Kałmuków i Mongołów po wielkoruskich blondynów, Białorusinów i Ukraińców, aż do naszych Jaśków i Antków [--]. Nie zabrakło również synów Izraela” (Lis-Błoński, 2013, s. 25); „pododdziały ochotnicze różnobarwnej i różnojęzycznej grupy wojsk [--]” (Lis-Błoński, 2013, s. 85). „Grupa ta składała się z rozmaitych narodowości. Prócz Rosjan byli tam Polacy kresowi, dońscy Kozacy, Turcy, Tatarzy, Ormianie, Żydzi itd. Były to oddziały o różnej kulturze religijnej, różnojęzyczne, lecz obce” (Lis-Błoński, 2013, s. 110). „Oddziały wzięte do niewoli, po oczyszczeniu ich z elementu komisarskiego, czyli rozstrzelaniu, segregowano i wcielano do różnych pułków i oddziałów tak, aby każdy posiadał podobny element ludzki, np. żołnierzy z okręgu piotrogradzkiego - razem, pskowskiego, Kozaków razem itd." (Lis-Błoński, 2013, s. 48).

Przyjęło się, iż określenie „krajowiec” zastrzeżone jest dla stosunkowo nielicznej grupy inteligencji na Litwie na początku XX w. Dla mnie osobiście to Bałachowcy, a nie nikt inny, byli w pełni tego słowa znaczenia KRAJOWCAMI byłego Wielkiego Księstwa Litewskiego. Tymczasem ten termin został już „zajęty”. Historycy białoruscy i litewscy zredefiniowali pojęcie „krajowość”, przykrawając ją dla swoich partykularnych interesów narodowych. Niepasujących do nowej definicji polskich „krajowców” przedstawiciele „krajowców” litewskich i białoruskich zgodnie wydziedziczyli, w czym znakomicie w charakterze parawanu pomógł im de nomine Polak i „polski” ekslegionista Michał Römer, człowiek od jesieni, o ile nie od lata 1918 r., w rzeczywistości nader niechętnie nastawiony do Polski i Polaków (Gierowska-Kałłaur, 2015a, ss. 341, 345-350 i dalsze). Również Graf Tyszkiewicz pisał, jeszcze w roku 1917, iż jest przeciwny powiązaniu „bytu tego kraju z bytem Warszawy i Krakowa”. I dalej „Czas już przypomnieć tym ludziom, że kto walczy nie za naszą odrębną całość, ten jest naszym wrogiem, ten działa jako wielki szkodnik i czas już tego pozbyć się. Wszyscy przybysze niech idą pracować do swoich pól [--] bo praca ich tutaj nieraz staje się tylko szkodliwą i wrogą dla nas" [LMAB, Fond 21-671, k. 33-34]. 
Ziemie byłego Wielkiego Księstwa Litewskiego zamieszkane były w czasie aktywności Bałachowców przez 8,5-9 milionów ludzi. Elity intelektualne - polskie, litewskie, białoruskie - stanowiły margines marginesu. Z perspektywy czasu, analizując ruchy wszystkich graczy na scenie politycznej tej epoki, konstatujemy, iż politykom litewskim przyświecała idea dobra Litwy narodowej, trudno natomiast określić co tak naprawdę przyświecało politykom białoruskim. Choć hasła, którymi posługiwali się białoruscy przedstawiciele wszystkich zwalczających się kierunków, były bardzo zbliżone.

Skoro termin „krajowcy” jest już przypisany wąskiej grupie inteligentów, pozostaje zadać pytanie - jak nazwać pozostałe ponad 8 milionów mieszkańców tego KRAJU, dawnego Wielkiego Księstwa Litewskiego, części składowej słynącej z tolerancji dawnej Rzeczypospolitej Obojga Narodów? Odpowiedzi na to pytanie nie ułatwia fakt, iż rozsiani na olbrzymim i źle skomunikowanym terytorium jego mieszkańcy, w swej masie, poza Polakami, pozbawieni byli świadomości politycznej i narodowej, i - szczególnie w grupie zamieszkującej ziemie białoruskie - dodatkowo mocno zrusyfikowani. Społeczność żydowska z racji zasad swojej religii żyła nieco wyalienowanym życiem, choć węzły gospodarcze i finansowe spajały ją z pozostałymi w sposób niezwykle istotny. W zasadzie jeżeli mieszkańcy ziem litewsko-białoruskich łączyli się wówczas, to łączyli się we wspólnoty terytorialne (krajowe) usiłujące - lepiej lub gorzej - bronić własnych, „krajowych” interesów. Gdyby traktować pojęcie krajowość dosłownie - to nikt inny tylko oni nosiliby to imię. Niekwestionowanym liderem jednej z takich „wspólnot krajowych” był Stanisław Bułak-Bałachowicz, a sława jego zataczała coraz szersze kręgi.

\section{O Bułak-Bałachowiczu w czasie działań roku 1920}

Cudzy sukces, nawet ten najciężej zasłużony, zawsze ma dwie strony medalu. Budzi u bliźnich zazdrość, cechę jak najbardziej ludzką. Czasem - zawiść posuniętą do chęci destrukcji pokłosia cudzego wysiłku. Dobrem równie pożądanym wśród kombatantów jest sława, jak też godne zaopatrzenie za swoje zasługi - zaopatrzenie zdrowotne, emerytalne, wdowie etc.

Co pisze sam Bułak-Bałachowicz o atmosferze panującej w Naczelnym Dowództwie Wojsk Polskich (dalej NDWP)? O roku 1920 pisze: „Gdy zwyciężałem, to mi nie raz zwycięstwo moje zabrano na swój rachunek” [CAW, sygn. I. 480.72, k. 15-16]. W roku 1930 pisze o swoich kłopotach: „Byłem pozostawiony dotychczas tak, jak na wojnie, jak partyzant, sam sobie" (podkr. JGK) [CAW, sygn. I. 480.72, k. 15-16].

W czasie wojny $1920 \mathrm{r}$. militarnie podporządkowany NDWP oddział Bałachowicza bił się z bolszewikami ramię w ramię z żołnierzami polskimi (Karpus, 1990, ss. 89-101). Bałachowiczowi do głowy w tym czasie nie przyszło zabiegać o status prawny swoich ludzi i swój własny, bo status ten wydawał się oczywisty. Równy. Tak nie było. I stąd płynęło poczucie zobowiązania generała wobec swoich żołnierzy po wojnie. Spomiędzy kart archiwaliów przechowywanych w CAW, a nawet z kart Bała- 
chowców Lisa-Błońskiego można wyczytać, iż oddział ten po zakończeniu działań wojny polsko-sowieckiej traktowany był jako niepotrzebny już, bezpłatny oddział janczarów. Po fiasku akcji mozyrskiej - dodatkowo - oddział z wielu względów bardzo niewygodny.

Najpowszechniejszym źródłem informacji o Bałachowcach i Bałachowiczu jest praca zatytułowana Bałachowcy Stanisława Lisa-Błońskiego, kierownika Oddziału Informacyjnego Dowództwa Grupy (Lis-Błoński, 2013). Na tę pracę powołują się wszyscy zajmujący się Bułak-Bałachowiczem, doczekała się nawet białoruskiego wydania z nie zawsze celnym komentarzem objętością przekraczającym niemal tekst oryginału (Вашкевіч, Чарнякевіч, \& Юркевіч, 2014).

Jednak w poszukiwaniu fabuły chyba mało osób zapoznało się z tym źródłem pod kątem zapisu klimatu epoki, stosunku NDWP do Bałachowicza i Bałachowców. Dzięki wysiłkowi Jacka Pelicy, po odświeżonej lekturze Bałachowców (reklamowanych jako Notatki oficera łacznikowego przy Ochotniczej Armii Sprzymierzonej z frontu wojny polsko-bolszewickiej 1920 roku), nie mogę oprzeć się wrażeniu, że ich autor, Stanisław Lis-Błoński, był po prostu zawodowo zazdrosny o sławę Bałachowicza. Przy zachowaniu uczciwości w kwestiach zasadniczych - w rzeczywistości z całą pewnością był niespecjalnie generałowi życzliwy.

Opisując swoje własne działania militarne (podkreślam: w pracy zatytułowanej Bałachowcy) Lis-Błoński jest bardzo szczegółowy i elokwentny: „po moim wyjeździe Grupa natychmiast rozpoczęła odwrót ze wsi Borowy i kontynuowała go nie mając bezpośredniego kontaktu z przeciwnikiem" (Lis-Błoński, 2013, s. 41).

Przy okazji opisywania okoliczności wycofywania się z Kamienia Koszyrskiego Lis-Błoński znów pisze dobrze o sobie, z pewnym dystansem do Bałachowicza: „Przerwana łączność na lewym, południowym skrzydle [--] i to mnie niepokoiło. U gen. Bałachowicza niepokoju nie dostrzegłem” (Lis-Błoński, 2013, ss. 51-54). [--] „Po moim raporcie gen Bułak Bałachowicz przyznał mi zasadniczo rację" (Lis-Błoński, 2013, s. 52). ,[--] udałem się po raz nie wiem który do generała i nagliłem do wycofywania się[--] wszedłem jeszcze raz i zameldowałem, że jeśli nie nakaże odwrotu ja się wycofuję" (Lis-Błoński, 2013, s. 53) [--] „przedtem kazałem wszystkim [--] przygotować się do wymarszu. Po moim oświadczeniu [--] generał rozkazał natychmiast wycofać się” (Lis-Błoński, 2013, ss. 53-54) „[--] Ja miałem minę tryumfatora” (Lis-Błoński, 2013, s. 55) „Dywizję [ja] prowadziłem na zachód” (Lis-Błoński, 2013, s. 57) „mnie, polskiemu oficerowi, synowi tej ziemi, który wśród tego różnorodnego elementu reprezentował wolną, niepodległą Rzeczpospolitą, o której suwerenność walczyli ramię przy ramieniu ci obecnie bez ojczyzny żołnierze [--]" (podkr. JGK) (Lis-Błoński, 2013, s. 59).

Te i inne fragmenty Bałachowców, które mogłabym tu mnożyć, utwierdzają mnie w moim przypuszczeniu, że militarna sława Bałachowicza była dla wielu ówczesnych polskich wojskowych źródłem lepiej lub gorzej skrywanej zazdrości. 
O żołnierzach Bałachowicza Lis-Błoński w Bałachowcach wcale nie pisał tak wiele... Większą uwagę w swej pracy spisywanej z dużego dystansu czasowego poświęcił opisowi negatywnych, zaobserwowanych wydarzeń skonfrontowanych z opisem własnych, bez skazy, zachowań. A o samym Bałachowiczu czytamy w zasadzie pomiędzy wierszami. Błoński faktycznie kilkakrotnie we wspomnieniach pisał ogólnie o Bałachowcach pozytywnie - o ich waleczności, ale częściej rzucają się w oczy konkrety, takie zapisy jak te: „panuje powszechny spokój; nie miejąc kontaktu z wrogiem wycofują się” (Lis-Błoński, 2013, s. 65), „Bałachowcom miny zrzedły” (Lis-Błoński, 2013, s. 73) „lotna dywizja [--] nie była niepokojona przez oddziały wroga” (Lis-Błoński, 2013, s. 43) - nie są w tej pracy rzadkością.

W lipcu 1920 r., w jednym z pisanych na bieżąco meldunków, czyli źródle znacznie cenniejszym dla historyka od przywołanych wspomnień, Lis-Błoński pisał bez żadnej autocenzury czy redakcji co następuje: „Dowódcą jest generał Stanisław Bułak-Bałachowicz przez wszystkich zwany »Batko«, człowiek o wysokiej dumie, chce być słynnym, dużo krzyczy, z żołnierzami bardzo blisko. Często z nimi mówi lub czyta gazety, czasem opowiada bajki. Żołnierze są do niego bardzo przywiązani” (podkr. JGK) („Raport por. Błońskiego”, 1990, s. 124).

Ciekawy jest również podobny raport tego samego autora z 30 VIII $1920 \mathrm{r}$. (Powstał w trzy dni po zawarciu umowy Sawinkow-Bałachowicz, o której za chwilę.) Lis-Błoński na potrzeby szefa Oddziału II Dowództwa 3 Armii sporządził charakterystykę obu braci Bałachowiczów (Raport Nr 3 Do Szefa Oddziału II D-wa 3 Armii Podpisał Błoński. Odpis. Kopia NDWP Oddz II M.P dnia 30 VIII 1920, cyt. za: Garlicki, 2003, ss. 283-300). Czytamy tam: „Mam wrażenie jednak że człowiek ten [Stanisław Bułak-Bałachowicz] chętnie by służył u Chińczyków lub Cyganów, byleby miał to co potrzeba i by dużo o nim w gazetach pisali. Przy mnie od 24 VII do 24 VIII był przy Grupie wszystkiego 16 dni, reszta w Warszawie, jednak należy zwrócić uwagę, że kiedy jest przy grupie, ani chwili nie może wytrzymać na miejscu, wciąż robi wypady. Stosunek jego do oficerów - koleżeński, większości mówi na »TY« i oni również. Jak się rozgniewa na oficerów wymyśla wobec wszystkich na rynku, czy w domu, a także szpicrutą wycina, często stosuje chłostę cielesną, pierwszy raz wylicza 25 itd. [---] Przy egzekucjach lubi być obecny; po jakimkolwiek zwycięstwie wszystkich żołnierzy spaja spirytusem i sam się napije, pow tórzy kilkakrotnie historię zwycięstwa i kładzie się zupełnie ubrany spać" (Raport Nr 3 Do Szefa Oddziału II D-wa 3 Armii Podpisał Błoński. Odpis. Kopia NDWP Oddz II M.P dnia 30 VIII 1920, cyt. za: Garlicki, 2003, ss. 283-300).

O Józefie w tym samym raporcie Lis-Błoński pisał w sposób następujący: „Brat jego pułkownik Józef Bałachowicz - jest spokojny i małomówny, jest bardzo dumny ze stanowiska, z żołnierzami z daleka, wyprawy robi albo urządza wtedy, kiedy już koniecznie potrzeba, sam zawsze w pierwszej linii. Po zwycięstwie wraca spokojnie dziękując żołnierzom za pracę. Następnie przebiera się w nowy mundur i tak spaceruje po wioskach lub ulicach 
miasta, aby na niego zwracano uwagę, śpi tylko w nocy. Nad sprawami administracyjnymi nigdy się nie zastanawia i nie wtajemnicza, żołnierzy krótko trzymać nie potrafi. Innej kary nie zna jak żołnierza lub oficera rozstrzelać, żyda lub chłopa powiesić" (Raport $\mathrm{Nr} 3$ Do Szefa Oddziału II D-wa 3 Armii Podpisał Błoński. Odpis. Kopia NDWP Oddz II M.P dnia 30 VIII 1920, cyt. za: Garlicki, 2003, ss. 283-300).

Swoją opinię o wrodzonej (?) brutalności Bułak-Bałachowicza Lis-Błoński zrewidował po latach pisząc „Wówczas nie było czasu, nie było innego sposobu postępowania, aby utrzymać karność i dyscyplinę w szeregach w obliczu wroga" (Lis-Błoński, 2013, s. 97).

Autorem kolejnego „Ściśle Tajnego Meldunku” nt. Grupy Bałachowicza z 16 października 1920 r. L.dz. 139 adresowanego do Oddziału II Dowództwa 3 Armii jest również Lis-Błoński [CAW NDWP I.301.8.416]. W porównaniu do raportu wcześniejszego mamy tu mniej kwantyfikatorów, więcej konkretów.

„---] Stan: a) 15\% starych z Kurlandii; b) bolszewicy wzięci do niewoli; c) 30\% oficerów i żołnierzy z Armii Polskiej [według Lisa-Błońskiego zainteresowanych grabieżą i bandytyzmem]. [--] [Nastrój] bandytystyczny [--] poziom umysłowy - b. niski. Część oficerów jest kokainiarzami dochodzącymi do idiotyzmu [--]. Stosunek tak oficerów, jak i żołnierzy jest do nas wciąż wrogi. Tłomaczy się to wrodzoną nienawiścią ku nam, chęcią bycia górą, a wobec niższego poziomu umysłowego ich żołnierzy i oficerów od naszych stąd nienawiść [--] Wartości bojowej - nie mają". Zarzut Lisa-Błońskiego o niskiej wartości bojowej tej jednostki - w raporcie z lata 1920 r. - był po prostu podły i autor formalnie wycofał się z niego w Bałachowcach (Lis-Błoński, 2013, s. 116 i in.). Cytuję dalej: „Co do nastroju ogólnopolitycznego kierowniczych jednostek, ostatni liczą się z siłą, a co najmniejsza z patriotyzmem Polski [--]. Tworzy się przy grupie Oddział II, na czele którego był ataman Iskra, który niby chciał zorganizować na modłę oddziałów II-gich WP. W organizacji tej jest masa b. żandarmów carskich, którzy zajęli się samowolnie rekwizycją biżuterii i pieniędzy [---] Szefem Intendentury jest żyd, który wg. słów oficerów, robi szalone interesy na aprowizacji, fasuje półtora razy tyle na Grupę, ile jest osób [---]. Przy Grupie pluton żandarmerii polskiej - 15 żołnierzy, wyrobionych i uczciwych żandarmów [---] stosunek do nich oficerów i żołnierzy jest nadzwyczaj wrogi, często żandarmi bywają w niebezpieczeństwie. [--] Ludność do bałachowców usposobiona wrogo choć sama z nimi rabuje [---]" [CAW NDWP I.301.8.416].

Uwagę zwraca fakt, iż jest to niezwykle rzadko spotykana w znanych mi dokumentach pozytywna relacja o działalności żandarmerii z okresu wojny polsko-bolszewickiej.

Gdy Błoński charakteryzował we wspomnieniach oddziały Bałachowicza, podkreślał ich „obcość” i „odmienność” od ,jednolitego Wojska Rzeczypospolitej”. Pisał: „wojsko gen. Bałachowicza wprawdzie walczy[ło] w obronie naszej Ojczyzny Polskiej, lecz jest obce, zupełnie różne od młodego, a jednak już jednolitego Wojska Rzeczypospolitej Polskiej” (podkr. JGK) (Lis-Błoński, 2013, s. 87). Według Błońskiego 
pod pretekstem przynależności do Grupy wszelka inna banda mogła robić co jej się żywnie podobało. Więcej, według Lisa Błońskiego żołnierz Bałachowicza czuł się zdeprymowany wycofując się do obcego kraju (Lis-Błoński, 2013, s. 59).

Stosowanie takiego typu określeń i podkreśleń było w mojej ocenie prostą konsekwencją faktu, iż Lis-Błoński był klasycznym przedstawicielem przeciętnego Polaka z Kongresówki, nieczującego wspólnoty z ludnością byłego Wielkiego Księstwa Litewskiego. Czytamy: „W Pińskich Błotach, zamieszkanych przez ludność, z którą nie jest się tak ściśle sercem wiązanym, obchodziliśmy się sprawiedliwie, lecz bez specjalnego sentymentu" (podkr. JGK) (Lis-Błoński, 2013, s. 74).

Obraz żołnierzy Stanisława Bułak-Bałachowicza został przez Lisa-Błońskiego wykreowany już w roku 1920, nie przesądzam z jakich pobudek. Może rzeczywiście tak Bałachowców postrzegał? Był to obraz uderzający obcością kulturową i ocenami pejoratywnymi z polskiego punktu widzenia. Niestety został bardzo skutecznie utrwalony przez różnorakie czynniki i siły polityczne, nie tylko polskie. Sam Błoński po latach pisze: „Jedni wojsko to uważali za symbol bohaterstwa, inni - za oddziały bandyckie, krwiożercze" (Lis-Błoński, 2013, s. 87). Tak naprawdę autor Bałachowców pisanych już po śmierci Józefa Bałachowicza uchyla się od otwartej oceny.

Nie twierdzę bynajmniej, że Bałachowcy byli z usposobienia ministrantami. Z prostego rachunku wynika, iż liczbę tzw. bolszewików w oddziałach Bałachowicza według obliczeń Oddziału II NDWP szacowano na 55\%. Pozostaje zadać pytanie, czy byli to istotnie „nawróceni” bolszewicy, czy też porwani przez wichry wydarzeń historycznych mieszkańcy tego KRAJU? Krainy z wielu względów pozostającej faktycznie na niższym poziomie intelektualnym od ziem byłego Królestwa Kongresowego. Czy przypadkiem nie byli to ludzie, którzy po prostu nie mieli specjalnego wyboru, gdy dostawali powołanie do carskiego wojska. Wybór również nie był duży, gdy carskie wojsko przestało istnieć. Świat, w którym się urodzili i żyli, po prostu przestał istnieć. Nie odpowiadał tym ludziom wybór między bolszewikami a Denikinem. Poddawszy się wyrozumiałemu wobec nich Bałachowiczowi, po bliższym go poznaniu, wiązali się z nim w przeważającej części dobrowolnie. Wiele na to wskazuje, że byli to ludzie mający silne poczucie wspólnoty swojego bezdomnego losu. I olbrzymie poczucie własnej „honorności” i własnej niezależności, co mogło razić tzw. rdzennych Polaków. W latach 1919-1920 żołnierze Baćki istotnie byli bezpaństwowcami. Zaciągnięcie się do oddziału Bułak-Bałachowicza dawało im namiastkę swobody i niezależności, dawało szansę na przyszłość. A Baćka dla dobra swoich ludzi gotów był współdziałać przeciw bolszewikom dosłownie z każdym. Po Mozyrzu (listopad 1920 r.), szansę widział już jedynie w kooperacji z Polską.

Z punktu widzenia Naczelnego Wodza wchłonięcie szeregowych czerwonoarmistów i ich resocjalizacja przez oddział Bułak-Bałachowicza były bardzo humanitarnym rozwiązaniem problemu. Takiej liczby jeńców nie tylko lotna brygada utrzymać i upilnować by nie mogła. Alternatywa była brutalna - w celu utrzymania bojowego 
potencjału własnych szeregów Bułak-Bałachowiczowi pozostawałaby fizyczna eliminacja zagrożenia, czyli sądy doraźne na krajanach własnych żołnierzy. „Słaby tylko rzeź wybiera" (Zygmunt Krasiński, Psalmy przyszłości. Psalm miłości w. 83). Bałachowicz - wbrew urobionej opinii - bynajmniej nie wybrał rzezi.

Lis-Błoński bardzo wyraźnie pisze w Bałachowcach: „Stale [Bułak-Bałachowicz] rzucał hasła, rzucał, że nie bije się z żołnierzami, nie walczy z narodem, tylko chce skończyć bratobójczą wojnę przez »demobilizację« armii sowieckiej i likwidację instytucji komisarzy" (Lis-Błoński, 2013, s. 249).

Lepiszczem i katalizatorem tej wieloetnicznej i wielokulturowej grupy „krajowej”, gwarantem jej lojalności wobec siebie nawzajem, była osobowość Stanisława Bułak-Bałachowicza. Nie wykluczam, iż wiele szeroko komentowanych (również przez Lisa-Błońskiego) zachowań Bałachowicza miało miejsce wyłącznie ze względu na ludzi, których Baćka wokół siebie skupiał.

Jak w każdym wielkim skupisku w czasie wojny i w szeregach Bułak-Bałachowicza znajdowali się szpiedzy i zdrajcy. Stąd sądy doraźne i egzekucje, o których Lis-Błoński pisze „wówczas nie było czasu, nie było innego sposobu postępowania, aby utrzymać karność i dyscyplinę w szeregach w obliczu wroga" (Lis-Błoński, 2013, s. 97), bez najmniejszego wątpienia miały miejsce. Błoński pisze jednak w Bałachowcach in extenso: „Niesprawiedliwe było oskarżanie Bałachowicza o takie czy inne rzezie, rabunki i gwałty. Przez cały czas mego pobytu w Grupie ani razu nie zanotowałem wypadku wydania wyroku śmierci przez generała lub jego brata na niewinnego" (Lis-Błoński, 2013, s. 249).

Fakt funkcjonowania w szeregach grupy Bułak-Bałachowicza dużej liczby ochotników - Żydów zgodnie współżyjących z żołnierzami-chrześcijanami doprowadziła Lisa-Błońskiego do kolejnego wniosku, że pogromy żydowskie były po prostu wytworem wojny, a nie jakiejś specjalnej odrazy Bałachowców do Żydów.

Bardzo charakterystyczna jest rozbieżność relacji Bułak-Bałachowicza i Sawinkowa w kwestii istnienia czy też nieistnienia oddziałów żydowskich w grupie Bałachowicza. Dyskusję na ten temat omawia J. Pelica w przypisie nr 3 (Lis-Błoński, 2013, ss. 25-26). Tam zwraca uwagę na fałszywą publikację w krakowskim „Naprzodzie” autorstwa rzekomego oficera Bałachowicza - płk. Lichaczewa z 25 lutego 1921 r. oraz skierowaną przeciw Bałachowcom kampanię polskiej prasy, która miała miejsce w 1921 i 1922 r. W 1921 r. (brak informacji, w którym półroczu) ukazały się też nakładem Narodowego Klubu Żydowskiego Posłów Sejmowych przy Tymczasowej Żydowskiej Radzie Narodowej dwa tomy dokumentów Inwazja bolszewicka a Żydzi. Z opracowań współczesnych warto zwrócić uwagę na wystąpienia w tej sprawie Rafała Bergera i Mikołaja Iwanowa (Berger, 2007; Iwanow, 2007, 2010). Sawinkow utrzymywał, iż oddziału żydowskiego nie było, Bałachowicz podawał, że liczył 70 osób. Lis-Błoński podaje, iż Żydzi mieli swój pododdział pod dowództwem por. Cejtlina, liczący ok. 300 osób (Lis-Błoński, 2013, s. 48). 
Inną jeszcze relację mamy od żandarma st. wachmistrza Krolala „O stosunkach wojskowych w Grupie Gen. Bałachowicza” z 3 września 1920 r. Czytamy w niej: "Antysemityzm doprowadzony do najwyższego stopnia: wyraża się w doszczętnem i systematycznym rabowaniu domów żydowskich. Dowództwa poszczególnych jednostek żadnych kroków celem ukrócenia nadużyć nie przedsiębiorą. Ma się wrażenie że oddziały żyją z rabunku [---]" [Odpis z odpisu M.p. 3/9 1920].

$\mathrm{Z}$ drugiej strony Lis-Błoński przyznaje, iż przedstawicieli narodowości Żydów na ziemiach wschodnich spotykało się właściwie wszędzie. Znajdowali się i po jednej, i po drugiej stronie frontu wojny polsko-sowieckiej. Ci z przeciwnej strony frontu oczywiście ginęli nie jako Żydzi, tylko jako przeciwnicy. A ofiarami gwałtów padali przede wszystkim - co oczywiście karygodne - najłatwiej osiągalni osiadli Żydzi po własnej stronie, których dodatkowo - jakby to brutalnie zabrzmiało - w tych ciężkich czasach było z czego rabować.

W memorandum Gminy Żydowskiej w Wilnie czytamy (k. 9 i dalsze) m.in., iż doktora Słonimskiego $\mathrm{w}$ trakcie potępienia godnych zamieszek $\mathrm{w}$ Wilnie $\mathrm{w}$ kwietniu 1919 r. okradziono na 100000 rubli, sklep Zalkinda zrabowano na 600000 rubli. Kolejne wymienione według nazwisk właścicieli sklepy ograbiono na sumę 270965 rubli. Dwanaście kolejnych wileńskich sklepów (wymienionych również z nazwiskami właścicieli) okradziono na sumę 2362719 rubli. Grabież wileńskich sklepów żydowskich sami zainteresowani szacowali na zawrotną jak na owe czasy kwotę 3333684 rubli. Wycena strat materialnych poniesionych przez społeczność żydowską w kwietniu 1919 r. w Wilnie całkowicie dominuje w treści tego memorandum [LMAB F. 255-549 k. 1-28].

Trzeba tu jednak zrobić jeszcze jedno istotne zastrzeżenie: ci nieszczęśliwi ludzie byli karygodnie gromieni przez wszystkie strony konfliktu na ziemiach wschodnich byłej Rzeczypospolitej Obojga Narodów. Należy też na marginesie zauważyć, że w Bałachowcach Lis-Błoński „murem stoi” za uczciwością Bałachowicza w kwestii rzekomych pogromów, jakich miał osobiście dokonać ze swoimi żołnierzami na Żydach.

Wiele na to wskazuje, że oddział Bałachowicza od sierpnia 1920 r. podporządkowany Rosyjskiemu Komitetowi Politycznemu, o czym za chwilę, nie był beniaminkiem Sawinkowa, co brutalnie musiało się odbijać na jego aprowizacji. To w oczywisty sposób demoralizowało i skutkowało występowaniem zjawisk niepożądanych w każdym oddziale. Rabowali wówczas wszyscy, o rabunkach Bałachowców wypadało jednak pisać i mówić, bo to w powszechnym odczuciu nie było Wojsko Polskie. Błoński pisze wyraźnie, iż samowolne zaopatrywanie się w żywność nieraz zdarzało się i w polskich oddziałach, choć było zabronione. „Trudno, by oko oficera w takim marszu mogło kontrolować każdego żołnierza [--]. To jest prawo wojny, Taki jest los żołnierza! [--] Rozumowano, że szkoda jest zostawiać »dobro« idącym za nami oddziałom bolszewickim, które rabowały wszystko, co było zdatne do użytku: od konia i bydła do ostatniego kawałka chleba" (Lis-Błoński, 2013, s. 65). 
Więcej, wygodnie było obciążać żołnierzy Bałachowicza odpowiedzialnością za tego typu wykroczenia. Choć trzeba przyznać, iż istotnie poszczególnych oficerów i szeregowych służących w oddziałach Bałachowicza pociągnięto w Polsce do odpowiedzialności sądowej w związku z tego typu ekscesami. Wobec generała Bałachowicza oficjalnych oskarżeń na drodze sądowej nie wysunięto, pomimo iż sam zainteresowany zmęczony wymierzoną przeciw sobie kampanią prasową w liście otwartym do Sejmu Rzeczpospolitej Polskiej (z 7 kwietnia 1922 r.) sam się domagał sądu nad sobą i - rehabilitacji [odpis LCVIA, Fond 281, op. 1, t. 12, k. 1-11]

Trzeba wreszcie zauważyć, że tekst Lisa-Błońskiego Bałachowcy nie jest pozbawiony delikatnie sączonych cienkich złośliwości i uszczypliwości. Autor m.in. pisze: „[w odniesieniu do Grupy Bałachowicza] używam słowa marsz nie zaś natarcie, ponieważ ani razu nie zdarzył się wypadek, aby Grupa idąc naprzód [--] natrafiła na poważniejszy opór ze strony nieprzyjaciela" (Lis-Błoński, 2013, s. 114). Oczywiście $\mathrm{w}$ kontekście informacji o podjazdowym charakterze walk oddziału Bałachowicza, jest to informacja neutralna. Podana w sposób oderwany od tego kontekstu, bez komentarza - w moim odczuciu brzmi jednak dość dwuznacznie.

\section{II}

\section{Debiut Bałachowicza i Bałachowców na scenie politycznej}

Jesień 1919 r. to otwarcie „białoruskiej” karty w życiu generała Bułak-Bałachowicza, człowieka, który nigdy nie ukrywał swej wybitnej niechęci do bolszewików, którzy $\mathrm{z}$ jego punktu widzenia stanowili pierwszoplanowe zagrożenie dla jego KRAJU. Cudzysłów przy „białoruskości” jest tu logiczny dla każdego, kto nie będzie skłonny lekceważyć podstawowej prawdy o generale, który konsekwentnie prowadził wojnę przeciw bolszewikom, współdziałając z każdym, kto miał taki sam cel.

Dnia 14 listopada 1919 r. na ręce Kostusia Jezowitowa, szefa misji wojskowo-dyplomatycznej Białoruskiej Republiki Ludowej (dalej BRL) w Rydze Bułak-Bałachowicz złożył deklarację obywatelstwa BRL i prośbę o przyjęcie na służbę. Celem nadrzędnym Bułak-Bałachowicza - co trzeba tu jeszcze raz bardzo wyraźnie podkreślić - była walka z Armią Czerwoną, a nie budowa BRL. Jezowitow bez trudu dostrzegł w „Batce” olbrzymi potencjał i - olbrzymią szansę dla BRL. Wystawił Bułak-Bałachowiczowi odręczną i niezmiernie wzniosłą opinię jako o Białorusinie.

Znakomitego żołnierza Stanisława Bułak-Bałachowicza polityka jako narzędzie walki nigdy nie interesowała i nie znał się na niej zupełnie. Opinia Lisa-Błońskiego jest jednoznaczna „Ostatni politykiem nie był, obchodziło go wyłącznie wojsko i jego wyszkolenie" (Lis-Błoński, 2013, s. 175).

W grudniu 1929 r. w liście do płk. Rudolfa sam generał pisał: „Polityka gorsza od wojny” [CAW, sygn. 1.480.72, k. 17]. Polityk BRL Konstanty Jezowitow wystawiający 
w listopadzie 1919 r. zaświadczenie poświadczające „białoruskość” Stanisława Bułak-Bałachowicza nie zdawał sobie sprawy, podobnie jak bardzo wielu mu współczesnych, iż Bałachowicz był „Białorusinem” jedynie w terytorialnym rozumieniu tego pojęcia. Bułak-Bałachowicz rychło zorientował się, że Jezowitow i BRL to za słaby sojusznik $\mathrm{w}$ walce $\mathrm{z}$ bolszewikami. Być może nie chodziło tu jedynie o białoruski potencjał militarny, ale i o polityczny? Poczucie dumy, ambicji, niezależności i swego rodzaju ułańskiej fantazji kazało Bałachowiczowi szukać optymalnego dla swoich ludzi rozwiązania.

\section{III}

\section{Wykonawca kolejnego „pomysłu na Białoruś” Józefa Piłsudskiego}

Kończyła się właśnie „epoka Judenicza”, który 22 stycznia 1920 r. wydał rozkaz o rozwiązaniu swojej armii, ale - pomimo posiadania środków na ten cel - nie kwapił się z wypłatą zaległego żołdu. „Baćka” bezwzględnie hołdujący, w sposób rzadko spotykany, zasadzie prostolinijnie pojmowanej „sprawiedliwości” (za co go zresztą kochali żołnierze), po prostu wziął sprawy w swoje ręce. W nocy z 28 na 29 stycznia w asyście oficerów rosyjskich i estońskich aresztował Judenicza i zmusił do wypłacenia żołnierzom posiadanych przez generała ogromnych sum pieniędzy przeznaczonych na cele likwidowanej armii. Następnie postanowił Judenicza ukarać, przekazując go w ręce bolszewickie (nie jest wykluczone, iż było to pozorowane działanie mające na celu upokorzenie i złamanie Judenicza, a nie - rzeczywiste wydanie go na pewną śmierć). Według rosyjskiego historyka Walerego Klawinga Bułak-Bałachowicz dokonał aresztowania generała wyłącznie $\mathrm{z}$ zamiarem przekazania go $\mathrm{w}$ ręce bolszewickie. Jeśli tak było w istocie, to władze estońskie udaremniły zamiar Bałachowicza. Wymusiły zawrócenie wozu z uwięzionym Judeniczem ze stacji Thapa. Jak wiadomo, ostatecznie Judenicz (wraz z żoną) uzyskał azyl od władz brytyjskich za pośrednictwem brytyjskiego poselstwa w Rewlu (Tallin).

Poczynania Bułak-Bałachowicza musiały być bacznie obserwowane w Belwederze. A Bałachowicz z kolei na przedwiośniu 1920 r. znał już „od podszewki” BRL-owski „potencjał” i po prostu wykazał troskę o zapewnienie swemu żołnierzowi maksymalnie wydolnego sojusznika w walce z bolszewikami. Gdy w lutym 1920 r., w przededniu wyprawy kijowskiej, a w trzy miesiące po spotkaniu Bułak-Bałachowicza $\mathrm{z}$ Jezowitowem, Baćka zwrócił się za pośrednictwem attaché wojskowego w Rydze do rządu polskiego z prośbą o przyjęcie jego oddziałów - w celu wspólnej walki z Armią Czerwoną "pod skrzydła Orła Białego” - natychmiast został pod te skrzydła zaproszony.

By spotkać się w Dyneburgu (Dźwińsku) z Rydzem-Śmigłym, oddział Bułak-Bałachowicza złożony $\mathrm{z}$ kilkuset ludzi musiał ( $\mathrm{w}$ warunkach zimowych, co jest 
równoznaczne z wyraźnym zostawianiem śladów przemarszu) wykonać kilkusetkilometrowy niezwykły konny rajd przez terytoria, na których praktycznie każdy walczył z każdym. Biała Armia walcząc z Armią Czerwoną, nie zamierzała uznać niepodległości Estonii, Łotwy i Litwy, Estończycy i Łotysze walczyli z Niemcami, Niemcy walczyli ze wszystkim zależnie od okoliczności etc. etc. Sława militarna Bałachowicza okazała się w pełni zasłużona. Jego oddział przeciął linię frontu bez strat i został w marcu $1920 \mathrm{r}$. $\mathrm{z}$ honorami powitany po stronie polskiej.

Terytorialne rozumienie białoruskości powiązane $\mathrm{z}$ atawistycznym antybolszewizmem Bałachowicza wykorzystał Józef Piłsudski w nowym wariancie swojej polityki wschodniej. Naczelnik Państwa Polskiego Józef Piłsudski w latach 1919-1920, konsekwentnie, w kilku etapach, podejmował próby politycznego scalenia w nowej, dwudziestowiecznej formie części składowych rozerwanego przez zabory terytorium byłej Rzeczpospolitej Obojga Narodów.

Istotny wpływ na plany Józefa Piłsudskiego miało wydanie przez Ententę 6 marca 1920 r. tzw. Noty Milleranda, w której zabraniano Polsce przeprowadzenia na ziemiach byłego Wielkiego Księstwa Litewskiego samookreślenia zapowiedzianego w odezwie wileńskiej z 22 kwietnia 1919 r. Do mieszkańców byłego W. Księstwa Litewskiego.

Wiosną 1920 r. narodowcy i Piłsudski (według wiarygodnego tajnego wewnętrznego biuletynu dla kadry Straży Kresowej) ,zamienili się” swoimi dotychczasowymi postulatami w sprawie zasięgu granicy wschodniej (Gierowska-Kałłaur, 2017, s. 227). Piłsudski chciał granicy z 1772 r., by mieć pole manewru dla rozwiązania problemu stosunków państwa polskiego z państwem ukraińskim i z Białorusinami w duchu przyjaźni i życzliwości, natomiast narodowi demokraci dążyli z jednej strony do oszczędzenia Rosji, z drugiej - do pozyskania dla Polski tylko takich obszarów, które będą dawały szanse na wchłonięcie w kompleks ziem etnicznie polskich (Gierowska-Kałłaur, 2017, s. 227).

W nowej sytuacji geopolitycznej, w której kropkę nad „i” stanowiła wspomniana Nota Milleranda, Piłsudski snuł plany posiadania obok polskiego wojska również siły militarnej oficjalnie stojącej poza jego zwierzchnictwem. Nie mógł przecież odpowiadać na arenie międzynarodowej za kogoś, kto nie jemu by podlegał politycznie.

Baćka znajdował się na terytorium kontrolowanym przez Wojsko Polskie. Oddział Bułak-Bałachowicza, $\mathrm{z}$ jednej strony $\mathrm{z}$ uwagi na wybitne poczucie niezależności swojego dowódcy, z drugiej - na rozsądek Bułak-Bałachowicza, dawał nadzieje, że we własnym interesie $\mathrm{w}$ czasie wojny $\mathrm{z}$ bolszewikami w sposób bezwzględnie lojalny podporządkuje się dyrektywom polskiego Naczelnego Wodza.

Piłsudski wykorzystał możliwość, która otworzyła się od stycznia 1920 r. z inicjatywy początkowo Czajkowskiego i Sawinkowa, potem już tylko Sawinkowa. W wyniku rozmów z budowniczym „Trzeciej Rosji” po 6 marca 1920 r. (tzn. po Nocie Milleranda, Gierowska-Kałłaur, 2003, s. 92, tekst w przypisie 117) Piłsudski zaangażował się we wspieranie (również finansowe) Rosyjskiego Komitetu Politycznego Sawinkowa. 
Podporządkowanie polityczne oddziałów Bałachowicza Sawinkowowi przy pozostawieniu podległości w sprawach wojskowych Naczelnemu Dowództwu Wojsk Polskich (dalej NDWP) wydawało się z punktu widzenia dalekosiężnej strategii znakomitym posunięciem.

Dnia 20 lipca 1920 r. doszło do spotkania Stanisława Bułak-Bałachowicza z Borysem Sawinkowem. Od pierwszej chwili Bułak-Bałachowicz darzył Sawinkowa olbrzymią niechęcią. Z kolei dla Sawinkowa Stanisław Bułak-Bałachowicz był byłym, nielojalnym współpracownikiem gen. Judenicza. Bałachowicz - nie bez presji wywieranej przez Naczelnego Wodza, wyraził gotowość politycznego podporządkowania siebie i swojego oddziału Rosyjskiemu Komitetowi Politycznemu. Takie posunięcie musiało zadowolić Rosjan i umożliwiało perspektywę zniwelowania „niepożądanej konkurencji” pomiędzy 3 Armią a oddziałami Bałachowicza.

Kwestię umów Sawinkow-Piłsudski szczegółowo omówił Leon Grosfeld w tekście zatytułowanym Piłsudski i Sawinkow (Grosfeld, 1965, ss. 108-131). Problematykę tę poruszał również Artur Leinwand (Leinwand, 1964, ss. 33-38).

Na podstawie umowy Polskiego Naczelnego Dowództwa z B. W. Sawinkowem wszystkie formacje rosyjskie na terytorium Rzeczpospolitej Polskiej zostały podporządkowane politycznie B. Sawinkowowi, a kwoty wypłacone przez rząd polski od 1 marca 1920 r. zarówno w naturze, jak też w pieniądzach, „a także te, które jeszcze będą wydatkowane", uznano za dług państwowy Rosji wobec Rzeczypospolitej Polskiej. Czyli za nakłady na militarnie podległy NDWP oddział Bałachowicza koszty mieli Polsce w przyszłości zwrócić Rosjanie, a odium oburzenia za ewentualne wykraczające poza zakres militarny działania Bułak-Bałachowicza spadałoby na Sawinkowa.

Dnia 27 sierpnia 1920 r. z rozkazu Naczelnego Dowództwa Bułak-Bałachowicz zawarł z Sawinkowem tajną umowę (Grosfeld, 1965, ss. 108-131). Borys Wiktorowicz Sawinkow i generał Stanisław Bułak-Bałachowicz doszli do porozumienia, iż w walce $\mathrm{z}$ bolszewikami oddział generała Bułak-Bałachowicza występuje pod wspólnymi hasłami oddziałów rosyjskich na terytorium polskim, na czele których stoi B. W. Sawinkow i [uwaga!] obaj dążą do zwołania w przyszłości zgromadzenia ustawodawczego, ziemi dla ludu, demokracji i utworzenia związku narodów - federacji (Grosfeld, 1965, ss. 108-131). W związku z ustaleniem jednolitych celów oddział generała Bułak-Bałachowicza podporządkował się pod względem politycznym i finansowym B. W. Sawinkowowi jako osobie stojącej na czele rosyjskiego centrum politycznego, mającego na celu odbudowę Rosji na fundamentach demokratycznych. W zakresie operacyjnym oddział generała Bułak-Bałachowicza działał samodzielnie, jednak w miarę możności starał się utrzymać więź strategiczną z działaniami innych oddziałów rosyjskich, podporządkowanych pod względem politycznym B. W. Sawinkowowi.

Uwaga 1. Problem dalszej zależności strategicznej generała Bałachowicza i innych oddziałów w wypadku jednolitego dowództwa oddziałów rosyjskich formowanych na terenie Polski i poza nim miał być wyjaśniony wówczas, gdyby taka sytuacja powstała, 
przy czym podporządkowanie polityczne generała Bałachowicza miało pozostać bez zmian, a Sawinkow miał go reprezentować pod względem politycznym zarówno wobec rządu polskiego, jak też wobec mocarstw sojuszniczych.

Uwaga 2. W przypadku posunięcia się oddziału Bułak-Bałachowicza „w głąb terytorium rosyjskiego" miał być przy nim (czyli przy Bułak-Bałachowiczu) zorganizowany samorząd lokalny i zarząd administracyjny.

Gdy 12 października 1920 r. doszło do zawieszania broni na froncie polsko-bolszewickim, Piłsudski i Wojsko Polskie nie mieli już pola politycznego manewru. Ale oddziały Rosyjskiego Komitetu Politycznego i podporządkowana mu Armia Ochotnicza dowodzona przez Stanisława Bułak-Bałachowicza nie były związane tym traktatem.

Nie można wykluczyć, iż Piłsudski, abstrahując od moralnego (a na pewno nie tylko moralnego) poparcia dla deklarowanej sawinkowowskiej wizji przebudowy Rosji w duchu demokratyzmu, postanowił wykorzystać nadarzające mu się nierealne marzenie Sawinkowa dla realizacji własnego celu. Jak? Realizując swój plan awaryjny. Budując od października 1920 r. pod osłoną Rosyjskiego Komitetu Politycznego, szablami Bałachowicza (i oświadczeniami Wiaczesława Adamowicza ojca) - Białoruś. Nie „kowieńsko-berlińską" i nie „sowiecką". „Trzecią Białoruś”. Białoruś przyjazną Polsce.

Chyba temu celowi przyświecało opracowanie zatytułowane „Program Rosyjskiej Narodowo-Ochotniczej Armii gen. Bułak-Bałachowicza" [12 października 1920 r.]. Dokument jest przechowywany w Białoruskim Instytucie Nauki i Sztuki w Nowym Jorku (Zbiór materiałów ulotnych do Powstania Słuckiego, 1920), a przywołany w swoim czasie przez Janusza Ciska w jego znakomitym doktoracie obronionym na Uniwersytecie Wrocławskim (Cisek, 1993). Cisek podkreślił w swoim tekście taktyczne położenie akcentu w tym programie na walkę $\mathrm{z}$ bolszewizmem w celu odbudowy Rosji, ale Rosji wolnej, zapewniającej swobodę dla wszystkich narodów i warunki ich rozwoju. Również Cisek wskazał na fakt, iż nastąpiła w tym czasie charakterystyczna zmiana podstaw działania oddziału Bułak-Bałachowicza - z ochotniczej formacji powstała Odrębna Armia Sprzymierzona (Rozkaz MSWojsk Nr 11262/B N. 20 Warszawa 28 września 1920, CAW Oddz. I E.58; Lis-Błoński, 1929).

Po zawarciu preliminariów pokojowych miało miejsce posiedzenie Rosyjskiego Komitetu Politycznego, w którym uczestniczyli obok Sawinkowa obaj Bałachowicze, Peremykin, i wojskowy przedstawiciel Wrangla - generał Piotr Machrow. Jako pierwszy cel działań zakładano oswobodzenie ziem białoruskich. Jest rzeczą niezmiernie charakterystyczną, iż właśnie w tym czasie generał Machrow informował o niebezpieczeństwie otwarcia kwestii białoruskiej (Cisek, 1993, s. 297).

Jesienią 1920 r. dzięki inicjatywie czołowego białoruskiego polonofila Pawła Aleksiuka powstał w Warszawie Białoruski Komitet Polityczny w składzie następującym: Paweł Aleksiuk, Wiaczesław Adamowicz (ojciec), Eugeniusz Mitkiewicz, Sienkiewicz i inni. Dnia 12 października 1920 r. komitet doszedł do porozumienia z generałem 
Stanisławem Bułak-Bałachowiczem (Krótki zarys, 1928, s. 99). O celach działania tej grupy można wnioskować na podstawie pisma Białorusinów skierowanego do gen. Bałachowicza: „Będąc głęboko przekonani, że armia Pana Generała w składzie której jest tak znaczna ilość Białorusinów, rzeczywiście przyniesie naszemu krajowi prawdziwą wolność i możność stworzenia swego państwowego bytu, przystępujemy do współpracy z W. Panem mocno wierząc, że nasza obecność doda hartu żołnierzowi białoruskiemu, wałczącemu o istnienie swej ojczyzny, a ludowi białoruskiemu, na ziemiach którego będzie się staczała walka, przyniesiemy obronę w zawieruchach wojennych, a również przyjdziemy z pomocą w utworzeniu niezbędnych form życia administracyjnego. Białoruski Komitet Polityczny zobowiązał się przeprowadzić akcję werbunkową do mającej powstać armii białoruskiej pod dowództwem gen. Bułak-Bałachowicza, ten zaś miał Białoruskiemu Komitetowi Politycznemu oddawać władzę cywilną na zajmowanych stopniowo terenach etnograficznie białoruskich" (Krótki zarys, 1928, ss. 99-100).

Nawet nie wszyscy oficerowie polskiego sztabu zdawali sobie sprawy, o co idzie gra.

Roman Umiastowski (1893-1982), major od 31 marca 1924 r. ze starszeństwem z 1 lipca 1923 r. i 106 lokatą w Korpusie Oficerów Piechoty, był dość reprezentatywnym przedstawicielem ówczesnej kadry oficerskiej NDWP. Cieszył się następującą opinią: „Charakter ustalony, siła woli bardzo duża, lecz wygórowana ambicja własna. Zarozumiały, jednak mało obowiązkowy i pilny. Oficer zdolny, mógłby osiągnąć poważne rezultaty, gdyby zechciał pozbyć się nonszalancji” [CAW, 1673/84/3, t. 15, k. 3].

Raport majora Umiastowskiego z 1921 r. w sprawie „rosyjskich armii” rzuca światło na wydarzenia towarzyszące zawarciu przez Polskę preliminarzy pokojowych z bolszewikami [RGWA, 461K, opis 1, dieło 128, k. 62]. Według Umiastowskiego „Dowództwo zaproponowało”, za pośrednictwem Rosyjskiego Komitetu Politycznego, dowódcom „rosyjskich armii”, generałowi Bałachowiczowi i generałowi Peremykinowi do wyboru:

- albo w dalszym ciągu prowadzić walkę z bolszewikami samodzielnie na swoje ryzyko i odpowiedzialność, w takim wypadku NDWP nie brało na siebie żadnej odpowiedzialności za mogące wyniknąć $z$ tego następstwa,

- albo z bronią w ręku ewakuować się z granic Polski.

Jak pisze Umiastowski: „Generałowie Bałachowicz i Peremykin wybrali kontynuowanie samodzielnej zbrojnej walki z bolszewikami, przyczem obie rosyjskie armie niestety [sic] nie połączyły się Generał Bułak-Bałachowicz, jak wiadomo, ruszył w kierunku Łunińca-Mozyrza, natomiast generał Peremykin nawiązując kontakt z wojskami ukraińskimi, dążył do połączenia się z armią Wrangla. Rosyjski Komitet Polityczny zawarł dwie umowy:

- z rządem Ukraińskiej Ludowej Republiki w osobie atamana Petlury w celu zabezpieczenia generałowi Peremykinowi możności wspólnych działań z ukraińskimi wojskami, 
- z Białoruskim Politycznym Komitetem Wiaczesława Adamowicza dla ułatwienia wojskowych operacji generałowi Bałachowiczowi w granicach Białorusi. [--] Dowódcy armii zależnymi byli od Komitetu tylko w sprawach politycznych [--]. Niektórzy jednak dowódcy armii, a także i wyżsi oficerowie armii uważali się jako powołani do samodzielnych politycznych wystąpień, które często były niewiadomymi dla R.K.P." (podkr. JGK) [RGWA 461K opis 1 dieło 128 k. 62].

Nasuwa się pytanie - o jakich to samodzielnych wystąpieniach politycznych w raporcie majora Umiastowskiego mowa? Ja czytam - Mozyrz, listopad $1920 \mathrm{r}$.

W spotkaniu polityków polskich i białoruskich "przed 2 listopada 1920 roku” (Шупа, 1998, dokument 2484) udział wzięli: ze strony białoruskiej Kuźma Tereszczenko, Liawon Dubiejkowski, Arkady Smolicz, Antoni Trepko i - prawdopodobnie - Roman Skirmunt, Sergiusz Baranow, Andrej Jakubecki, jak też pozostający w kontakcie z Radą Najwyższą Paweł Żawryd. Ze strony polskiej - w opublikowanym dokumencie imiona nie są rozszyfrowane - [prawdopodobnie Konstanty] Gordziałkowski, [który swoim czasie był członkiem Komisji Litewskiej Tymczasowej Rady Stanu], [prawdopodobnie Czesław] Krupski, który był naczelnikiem Wydziału Narodowościowego Komisariatu Generalnego Zarządu Cywilnego Ziem Wschodnich i Sekretarzem Generalnym Komisji Administracyjnej, [prawdopodobnie Mirosław] Obiezierski (brat Mieczysław był zatrudniony w Komitetu Obrony Kresów na dwóch etatach, od stycznia 1920 r. był szefem Wydziału Ogólnego w Sekcji Aprowizacyjnej, w okresie pełnienia funkcji zdecydowanie wolał „wywozić niż wwozić”), [Ignacy?] Porębski (z Mińska), A. Rożnowski - zwolennik federacji, rozmówca Macieja Glogiera w lutym 1920 r. (Gierowska-Kałłaur, 2003, s. 209). Narada dotyczyła „Akcji Słuckiej”, której celem być miało nie tylko uwolnienie kraju od bolszewików, ale też osiągnięcie niepodległości Białorusi. Niepodzielność Białorusi miała być osiągnięta w drodze federacji z Polską i poprzez ściślejszy związek z Litwą Środkową, która jeszcze przeżywała swoje pierwsze 72 dni (Gierowska-Kałłaur, 2005, ss. 117-125). Miał być zwołany Sejm Ustawodawczy Białej Rusi. Prawowity, a nie samozwańczy rząd w ustalonym składzie 50\% Białorusinów, 40\% Polaków, 10\% Żydów powołany miał być przez Radę Najwyższą. Jednym słowem ta planowana państwowość „w planach Piłsudskiego według źródeł białoruskich” miała być niewątpliwie „białoruska” (Шупа, 1998, dokument 2484)

Według informacji Oddziału II jeszcze 14 listopada 1920 r. Zjazd Białoruski Słucczyzny podjął uchwałę o ostrzu antysowieckim, wzywając do utworzenia wolnej Białorusi w granicach etnograficznych oraz jednocześnie do serdecznego powitania „naszej siostry Polski”. W Słucku pomimo przybycia 15 listopada 1920 r. osobistych delegatów Bałachowicza: jego brata Józefa, Samusewicza i Krzyżanowskiego, rząd dusz przechwycili eserzy zorientowani na konsekwentnie niechętną Polsce Białoruską Republikę Ludową (dalej BRL = BNR) w Kownie. Probałachowiczowsko nastawiona trójka organizatorów zjazdu, czyli Arseniusz Pawlukiewicz, Anton Baczko i Jan Macelli została zepchnięta do defensywy i według znanej relacji Konstantego Jezowitowa 
z 1944 r. nieskutecznie usiłowała ratować sytuację „metodami terroru”. Sytuacji nie ułatwiał Bałachowiczowi fakt, iż według relacji Pawła Żawryda z 1930 r. Rada Najwyższa w Warszawie odmówiła jakichkolwiek rozmów z Bałachowiczem, o co generał uporczywie zabiegał. W Słucku zaś snuto plany jak „wyrwać” formujące się pod Bałachowiczem oddziały spod jego wpływu. To niezrozumiałe dla Bałachowicza zachowanie wynikało między innymi z faktu zawarcia 11 listopada 1920 r. przez białoruski rząd Wacława Łastowskiego umowy w Kownie z władzami niechętnej Polsce Litwy o współpracy polityczno-ekonomicznej. Łastowski w imieniu BRL zrzekł się białoruskich roszczeń do Wilna jako swej stolicy na rzecz Litwinów. Zadeklarowano wspólny litewsko-białoruski front przeciw Polakom.

W pięć dni później, 16 listopada 1920 r. w Mozyrzu Stanisław Bułak Bałachowicz ogłosił powstanie Białoruskiej Republiki Ludowej (bis) z uczestnikiem pierwszego Zjazdu Wszechbiałoruskiego - Wiaczesławem Adamowiczem seniorem jako premierem na czele. Bułak-Bałachowicz ogłosił się wówczas Naczelnym Wodzem Białorusi. Niezwykle charakterystyczna była reakcja Borysa Sawinkowa na wieść o tej deklaracji, zgodnej przecież z punktami umowy sierpniowej, którą sam zawarł z Bałachowiczem. Według podpisanej odręcznie relacji Stanisława Bułak-Bałachowicza Borys Sawinkow miał mu wykrzyczeć w twarz: „Gdybym był wiedział, że o Białą Ruś chodzi, nigdy w życiu bym nie poszedł!” [patrz Aneks]. Słucka Rada Białoruska negatywnie odpowiedziała na tę ofertę, odrzucając współpracę z Bałachowiczem i zdecydowanie deklarując podporządkowanie rządowi BRL w Kownie. Tak więc kolejna inicjatywa skierowana pod adresem Białorusi ze strony Józefa Piłsudskiego trafiła w białoruską polityczną próżnię. Jest jednak ciekawe, że dokładnie tego samego dnia, 16 listopada 1920 r., Arkady Smolicz napisał list do Ministerstwa Spraw Zagranicznych w Warszawie w sprawie otrzymania od Polski subsydiów dla organizacji białoruskich na mocy umowy polsko-białoruskiej z 24 marca 1920 r. Czyżby w łonie polityków BRL istniał dwugłos i eserzy, którzy przejęli Radę Słucką postawili kowieńską „centralę” przed faktem dokonanym, co skrzętnie ukryto ze względów wizerunkowych? A może polityka BRL wobec Polaków polegała po prostu na umiejętnym pozyskiwaniu od nich dotacji na cele niezmierzające bynajmniej do polsko-białoruskiego pojednania?

Na polu walki Bałachowicz nie miał sobie równych. Udział oddziałów Bałachowicza w lecie $1920 \mathrm{r}$. w wojnie z bolszewikami (od ostatnich dni czerwca) skutkował zdecydowanie większą liczbą sukcesów niż niepowodzeń, co można ustalić w oparciu o źródła. Zagadnieniu temu poświęcił wspomniane już osobne opracowanie Zbigniew Karpus (1990). Zbiór wojennych komunikatów prasowych Sztabu Generalnego Wojska Polskiego - jak ustalił M. Cabanowski - aż dwunastokrotnie przywoływał jego sukcesy militarne. I to w sytuacji, gdy fakt pomijania sukcesów grupy generała Bałachowicza w komunikatach wojennych zwracał uwagę - nawet Karola Wędziagolskiego (2007). Poruszały ten problem liczne opracowania historyczne (Lis-Błoński, Tadeusz Kutrzeba, ale przede wszystkim Grzegorz Łukomski, Bogusław Polak, Mieczysław Wrzosek, 
Lech Wyszczelski, Oleg Łatyszonek). Świadczy o tym również osobiste podziękowanie Naczelnego Wodza za postawę w czasie wojny polsko-bolszewickiej. Jak ustalił Zbigniew Karpus, oddział generała Bułak-Bałachowicza do 30 września 1920 r. znajdował się w bezpośredniej styczności z nieprzyjacielem lub na jego tyłach, z sukcesem niszcząc linie komunikacyjne bolszewików. Ulubioną formą działania Bałachowicza były właśnie te wypady na tyły, które były możliwe - co trzeba koniecznie podkreślić - wyłącznie dzięki życzliwej generałowi sieci miejscowych informatorów.

W dyplomatycznych salonach w czasie toczącej się latem roku 1920 wojny Bułak-Bałachowicz, żołnierz z krwi i kości, oczywiście podporządkował się Naczelnemu Wodzowi. Wojna ma swoje prawa i wymaga subordynacji podwładnych. Piłsudski był jednak nie tylko Naczelnym Wodzem, ale i Naczelnikiem Państwa, politykiem wbrew piętrzącym się trudnościom $\mathrm{z}$ determinacją usiłującym zrealizować swoją wizję polityki wschodniej.

Jest istotnym pytaniem badawczym to, czy w ogóle Stanisław Bułak-Bałachowicz zdawał sobie w 1920 r. sprawę ze swojej „pozycji” w nowej kombinacji politycznej Piłsudskiego? Odnoszę wrażenie, że przyjęła się opinia, iż ten znakomity dowódca nie był tego do końca świadom. Być może jednak było inaczej - niedoszły białoruski Naczelny Wódz epizod ten wyparł ze swej pamięci, gdyż odczuł ten afront jako niespodziewaną osobistą i dotkliwą porażkę?

Hipotezę tę może poprzeć relacja Lisa-Błońskiego, który wyraźnie pisze o „poważnych nieporozumieniach", do których dochodziło między nim a Bałachowiczem w kwestii organizowania życia pokojowego w okresie „przed Mozyrzem” w poszczególnych miejscowościach na „rosyjski sposób” (Lis-Błoński, 2013, ss. 175-176). W Bałachowcach czytamy: „prócz pułków składających się z rosyjskich obywateli, były oddziały złożone z samych Białorusinów. Ci ostatni uważali, że teren objęty przez Grupę wojsk gen. Bałachowicza jest integralną częścią Republiki Białoruskiej. I te oddziały zaczęły również, gdzie tylko się dało, urządzać wioski i gminy na swoją modłę. Na terenie wytwarzała się dziwna atmosfera; była tam po prostu wieża Babel. Były też oddziały, które nie rościły sobie pretensji do tego terytorium” (Lis-Błoński, 2013, ss. 175-176). Hipotezę tę poprzeć mogłaby nagła zmiana orientacji Bałachowicza - dopiero pod wpływem fiaska Mozyrza stał się tzw. stuprocentowym Polakiem.

Oczywiście nie mogło się Sawinkowowi podobać, że w przeciwieństwie do niego „Białorusin” Bułak-Bałachowicz wydawał się o rzeczywistych celach akcji mozyrskiej bardzo dobrze poinformowany. Sądząc z emocjonalnego listu Bułak-Bałachowicza do Borysa Wiktorowicza Sawinkowa, ten ostatni dał się oszukać Piłsudskiemu, przekonany, że jedynym celem Naczelnika Państwa Polskiego jest - zgodnie z oczekiwaniami Wrangla - antybolszewicka krucjata i prewencyjna budowa Rosji demokratycznej. W Mozyrzu Sawinkow zrozumiał, że o mały włos nie został wykorzystany.

Kolejny plan białoruski Piłsudskiego, niewcielony w życie w Mozyrzu, nie był zgodny z rzeczywistymi planami Sawinkowa. Dlatego uważam, że podpisa- 
nie porozumienia 16 listopada 1920 r. w Mozyrzu między Rosyjskim Komitetem Politycznym (dalej RKP) a Komitetem Białoruskim Wiaczesława A. Adamowicza było po prostu wymuszone na RKP okolicznościami. Był to jedynie ruch fasadowy, gdyż Sawinkow, ze względu na swoją własną sytuację na białorosyjskiej scenie politycznej absolutnie nie zamierzał w 1920 r. budować państwa białoruskiego. Czyli - nie zamierzał przyłożyć ręki do jakiejkolwiek fragmentaryzacji wymarzonej „Trzeciej Rosji”.

Z politykami białoruskimi w ogóle się na scenie światowej polityki nie liczono, co najwyżej wykorzystywano ich ambicje. Sygnatariusze rosyjsko-białoruskiego porozumienia Wiaczesław Adamowicz i Paweł Aleksiuk - w wyniku zakulisowych intryg białorusko-białoruskich - znajdowali się na marginesie białoruskiej sceny politycznej. Piłsudski już nie mógł im pomóc.

RKP po internowaniu rosyjskich oddziałów wojskowych zmienił nazwę na Rosyjski Komitet Ewakuacyjny (REK) ewentualnie Komisję Likwidacyjną Rosyjskiego Komitetu Ewakuacyjnego. Dla oficjalnego występowania i nawiązania stosunków $\mathrm{z}$ rządem polskim używał z kolei nazwy Rosyjski Komitet Opiekuńczy nad Internowanymi. W Wilnie określano go natomiast mianem Warszawska Grupa Polityczna. Dla jasności przedstawianego tu wywodu używać będę konsekwentnie nazwy RKP/ REK, tym bardziej, iż nawet protokoły REK z roku 1921 zatytułowane są „Protokół posiedzenia RKP"1.

Do anulowania porozumienia RKP (vel REK) i BRL doszło w osiem miesięcy później, w czerwcu 1921 r. w trakcie narady przedstawicieli Rosyjskiego Politycznego Ewakuacyjnego Komitetu w Polsce i przedstawiciela Białoruskiego Wojskowo-Politycznego Centrum.

Posunięcie to strona rosyjska osłodziła Białorusinom opracowaniem „Prognozy politycznej dla Białorusi” jako dla podmiotu politycznego „nierozrywnego”, sporządzonej przez prawą rękę Sawinkowa i agenta Czeka w jednej osobie - Aleksandra Arkadiewicz Derentala pseudonim Dikgof (inne formy zapisu nazwiska: Dikgoff-Derenthal, Dickhoff-Derenthal, Dickhof-Derenthal również Derentel), który występował w imieniu Rosyjskiego Politycznego Ewakuacyjnego Komitetu w Polsce.

Lis-Błoński winą za niepowodzenie akcji mozyrskiej jednoznacznie obwiniał Sawinkowa. Cytuję wypowiedź Błońskiego w tej kwestii: „Białoruski Komitet Polityczny wszedł w kontakt $\mathrm{z}$ Sawinkowem na czele, który w gruncie rzeczy był organizacją rosyjską i w akcji tej więcej szkody przyniósł niż korzyści" (Krótki zarys, 1928, s. 100). Powstanie słuckie Lis-Błoński uznał za „spóźnione echo walk białorusko-bolszewickich", a słowem nie wspomniał o jakże ważnym polsko-białoruskim spotkaniu, które miało miejsce w początkach listopada (przed 2 listopada 1920 r.; Шупа, 1998,

\footnotetext{
${ }^{1}$ Odnalezione w Fondzie Trofiejnym w Moskwie przygotowuję do edycji źródłowej.
} 
dokument 2484), o którym wspomniano wcześniej. Warunkami białoruskiego sukcesu miały być: brak istnienia wewnętrznych tarć wśród Białorusinów, oparcie władzy na samorządach oraz białoruska współpraca z Bułak-Bałachowiczem. Żaden z nich nie został przez Białorusinów spełniony.

Trzeba powiedzieć wyraźnie, że Piłsudski po raz kolejny chciał coś dobrego zrobić dla Białorusinów i po raz kolejny Polska została potraktowana przez polityków białoruskich nie jak „siostra”, lecz jako sponsor. Białorusini znowu nie wykorzystali kolejnej szansy podsuniętej im przez Naczelnika Państwa Polskiego. Zastrzec tu należy - szansy niegwarantującej sukcesu, ale im go umożliwiającej.

W moim osobistym odczuciu - sojusz z „Polską Piłsudskiego” był w tym czasie jedyną realną białoruską szansą. Jak pisze Lis-Błoński, Rada Białoruska w Słucku jedynie „skorzystała” ze stworzonej przez Piłsudskiego (za sprawą obecności Bałachowicza) koniunktury. Z jakim efektem - wiadomo. To jednak już odrębna historia.

\section{IV}

\section{Zemsta Sawinkowa?}

\section{Kwestia antysemityzmu w powojennej Europie i pogromów Żydów na forum międzynarodowym}

Antysemityzm Europy lat 1919-1920 był powszechny. To temat jednak na osobne omówienie. Uważam, i chyba nie jestem w tej kwestii odosobniona, że antysemityzm ten miał podłoże ekonomiczne. To ekonomia w sposób bezwzględny rzutowała na kwestie przeżycia również na ziemiach północno-wschodnich. W okresie istnienia Zarządu Cywilnego Ziem Wschodnich (dalej ZCZW) (1919-1920) na terenach mu podległych sporządzono statystyki umieralności niemowląt. Ich analiza wykazuje, iż umieralność żydowskich niemowląt na 100 urodzeń była dwa razy niższa, niż umieralność we wszystkich pozostałych badanych grupach narodowościowych. A ludność miejscowa, bynajmniej nie znając tych statystyk, czerpała swą wiedzę z obserwacji.

Do karygodnych ekscesów antyżydowskich, mających na celu wejście w posiadanie żydowskiego mienia, dochodziło po wszystkich stronach frontów, i na północy, i na południu. Grupa rabowana broniła się. Żydzi czuli się zagrożeni i trudno im się dziwić.

Przypomnijmy jednak. To w Niemczech wydano w 1921 r. ówczesny „komiks” zaliczany dziś przez Austriacką Bibliotekę Narodową do „niemieckiej liryki dwudziestowiecznej”. Wydawnictwo to zatytułowane było: Totengräber Rußlands (Grabarze Rosji; Eckart, 1921). Obrazki z biogramami-wierszykami poprzedził wstęp $O \dot{z} y d o w s k i m$ bolszewizmie autorstwa skądinąd znanego Alfreda Rosenberga.

Ja trafiłam na informacje o wielotysięcznych żydowskich ofiarach pogromów po stronie ukraińskiej, przypadkowo pozyskane w czasach ZCZW przez Wojsko Polskie, 
które - tylko przez głupotę NDWP - nie zostały spożytkowane w roku 1919 przez polskie Ministerstwo Spraw Zagranicznych.

Należy po prostu założyć, że do ekscesów dochodziło w wielu miejscach i wielu było ich sprawców. W oddziałach Bałachowicza niewątpliwie też niejednokrotnie dochodziło do ekscesów. Nie tylko antysemickich. Trudno jednak za każdy indywidualny przypadek obarczać winą personalnie Bałachowicza (por. Engelstein, 2018, ss. 308-312; Smele, 2017, ss. 241-243; Волков, 2010, s. 301; Клавинг, 2003, ss. 402-404 i inni).

$\mathrm{W}$ ściśle poufnym raporcie $\mathrm{nr} 1187 \mathrm{z}$ poselstwa polskiego w Paryżu z dnia 13 grudnia $1921 \mathrm{r}$. zatytułowanym „Konferencja Waszyngtońska i sprawy rosyjskie. Stanowisko Żydów” a sporządzonym przez attaché wojskowego czytamy: „Na ostatnich konferencjach ogólnożydowskich w Karlsbadzie i Berlinie zapadło postanowienie niedopuszczenia za wszelką cenę do anarchii w Rosji, albowiem anarchia kończy się zawsze pogromem Żydów [--]. Postanowiono udzielić najdalej idącego poparcia ruchowi ewolucyjnemu w Rosji za pomocą całego aparatu finansowego, będącego w rękach żydowskich. Zawarto porozumienie z finansjerą żydowską w Ameryce. Żydzi będą popierać wysunięcie kwestii rosyjskiej na konferencji waszyngtońskiej oraz kandydaturę Krasina, który ich zdaniem nie jest bolszewikiem, tylko socjaldemokratą i jako jedyny może przeprowadzić pokojową ewolucję" [dodać należy, że według polskich źródeł informacji z epoki takie stanowisko zgodne było z założeniami polityki Niemiec i Anglii; RGWA, 308K, opis 9, teczka 744, k. 385-386]

\section{Pozycja Sawinkowa w roku 1921}

Józef Piłsudski - przypomnijmy - był w tym czasie jedynym sponsorem inicjatywy Sawinkowa, a ten był osamotniony. Sawinkow już nie był potrzebny „Rosji nie -Trzeciej”.

RKP był po 12 października 1920 r. pozbawiony jakiejkolwiek realnej władzy. Komitet spełniał jedynie rolę pośrednika pomiędzy NDWP a rosyjskim „komandnym sostawom", zapewniającym fundusze dla wojska. Oddział skalbmierzycki został przemianowany przez generała Wrangla na 3 Rosyjską Armię, a dowódcą został mianowany generał Borys Piermykin [Piermikin]. Podporządkowany został bynajmniej nie Rosyjskiemu Komitetowi Politycznemu, lecz głównodowodzącemu Zbrojnymi Siłami Rosji.

\section{Pozycja Bułak-Bałachowicza w roku 1921}

Wydaje się, że - po czasie - Bułak-Bałachowicz miał sam do siebie pewien żal, że uległ presji Naczelnego Wodza i zaaprobował instrumentalne użycie swoich żołnierzy, ludzi z różnych względów tak mu oddanych, w budowie mirażu Białorusi, mirażu, z którym sam generał wiązał chyba wielkie nadzieje. W 1920 r. był jednak żołnierzem, nie politykiem, i była wojna. Wojna się skończyła. O ile Bułak-Bała- 
chowicz czuł się zobligowany do bezwzględnego posłuszeństwa wobec Naczelnego Wodza armii, z którą się sprzymierzył w czasie wojny, to już nie czuł się w obowiązku podległości wobec Naczelnika Państwa w czasie pokoju. Tym bardziej, że nie raz i nie dwa dawano mu odczuć w NDWP, iż jest „Rosjaninem”. Do tego dochodził bardzo istotny czynnik ekonomiczny - jego ludzie, jako formalnie niebędący na służbie Wojska Polskiego, nie byli opłacani z polskiej szkatuły. Wdowy i sieroty po poległych bałachowcach nie miały żadnego zaopatrzenia, bo były wdowami „rosyjskiej armii”. Tymczasem oddziały Sawinkowa jesienią 1920 r. otrzymywały zaopatrzenie i kredyty widoczne gołym okiem. Musiała się nie podobać Bułak-Bałachowiczowi swoista abolicja, jakiej udzielono tym, ze znanych Baćce przestępców wojennych, z kręgu oddziałów Sawinkowa, którzy zadeklarowali udział w akcjach planowanych przez Borysa i Wiktora Wiktorowiczów Sawinkowych na rok 1921 (mowa o akcji „Wilk”).

Sytuacja stawała się coraz bardziej napięta, tym bardziej, że żołnierze Bułak-Bałachowicza stali się de facto jedyną grupą, którą opinia publiczna głośno i bezrefleksyjnie zaczęła obwiniać o wszelkie nieprawości, które w czasie walk i wojny zdarzają się we wszystkich armiach i na wszystkich frontach. Początki tej akcji datować należy już od listopada 1920 r. (wtedy posłowie żydowscy interpelowali w Sejmie w tej sprawie), lecz jej olbrzymie nasilenie miało miejsce - podkreślmy dopiero w latach 1921/1922.

\section{Plany Sawinkowa}

Polityka to sztuka wykorzystywania możliwości. Niechęć Sawinkowa do Bułak-Bałachowicza z jednej strony i konieczność odcięcia się przez „demokratycznych Białych Rosjan” od infamii pogromowej z drugiej miały swoje znaczące konsekwencje wiosną $1921 \mathrm{r}$.

Jedynym realnym źródłem finansowania dalszej akcji zmierzającej do budowy „Trzeciej Rosji”, źródłem na miarę oczekiwań Sawinkowa były koła bankierskie. Bankierami, na których liczono, byli przeważnie Żydzi (wyjątkiem potwierdzającym regułę była osoba Karola Jaroszyńskiego - zmarłego we wrześniu 1929 r. w Warszawie finansisty z Sankt-Petersburga, sponsora Uniwersytetu Lubelskiego i autora jakiejś nieprzyjętej przez RKP/REK propozycji, która napłynęła do Komitetu z Paryża w 1921 r.).

Dużymi pieniędzmi i jeszcze większymi kontaktami w świecie bankierskim dysponował Piotr Mojsiejewicz Rutenberg (czyli Pinchas Rutenberg), do którego RKP/ REK zwracał się o wsparcie aż do 30 sierpnia $1921 \mathrm{r}$.

Rutenberg urodził się 24 stycznia 1878 r. w Rosji a zmarł 4 stycznia 1942 r. w Jerozolimie. Był synem kupca i inżynierem z zawodu. Edukował się na Petersburskiej Politechnice. Zaangażował się w ruch rewolucyjny. Jako socjalrewolucjonista brał udział w wydarzeniach roku 1905 a w 1906 r. był organizatorem zabójstwa Gapona w Jeziorkach pod Petersburgiem (wówczas współpracował m.in. z Derenthalem). 
Rutenberg ratując się przed aresztowaniem, uciekł na emigrację, gdzie w 1909 r. opublikował swoje wspomnienia Zabójstwo Gapona. Autor ten najwyraźniej był człowiekiem o rozdwojonej tożsamości. Czuł się rosyjskim socjalrewolucjonistą, a jednocześnie powszechnie znane były jego sympatie do ruchu syjonistycznego. Zorganizował w sierpniu 1915 r. w Nowym Jorku Europejski Socjalistyczny Komitet w celu agitacji zmierzającej do zwołania żydowskiego kongresu i postawienia na nim kwestii Palestyny i narodowych praw Żydów żyjących w Rosji, Austrii i Rumunii. W roku 1915 mieszkał w Genui. Do roku 1917 - w Nowym Jorku. Po rewolucji lutowej powrócił do Rosji i był pomocnikiem członka Rządu Tymczasowego N. Kniszkina. Dał się poznać jako zawzięty przeciwnik bolszewików. Aresztowany po przewrocie październikowym, spędził w więzieniu sześć miesięcy. W 1919 r. ponownie wyemigrował. Wyjechał do Palestyny, gdzie zbudował kilka elektrowni. Został wkrótce dyrektorem Korporacji Energetycznej i przygotowywał plany elektryfikacji i nawodnienia południowej Palestyny i wykorzystania bogactw naturalnych.

O aktywności i planach Rutenberga związanych z Palestyną Sawinkow mógł wczesną wiosną $1921 \mathrm{r}$. jeszcze nie wiedzieć. W $1921 \mathrm{r}$. RKP/REK bardzo liczył na poparcie finansowe Rutenberga i jego wsparcie u innych bankierów. Rutenberg mógł być przez Rosjan w Warszawie w 1921 r. postrzegany jako bogaty rosyjski Żyd, rzecz jasna współczujący z odczuciami bliskich ofiar pogromów, przypisywanych przez vox populi tylko i wyłącznie oddziałom Bałachowicza. Tymczasem niemal wszystkie zachowane znane (i często cytowane) opinie o antysemityzmie oddziałów Bałachowicza (oprócz opinii Lisa-Błońskiego, żandarma Korola i interpelacji posłów żydowskich w warszawskim Sejmie) pochodzą z okresu nie wcześniejszego niż kwiecień 1921 r., na co chyba mało kto zwracał - i nadal zwraca - uwagę.

RKP/REK kontynuował ożywioną działalność na polu międzynarodowym. Sawinkowowi pilnie potrzebne były nowe pieniądze na działalność. Między innymi usiłował od 17 marca 1921 r. przechwycić kontrolę nad wybuchem niezadowolenia społecznego w Kronsztadzie i z jego inicjatywy po pięciu miesiącach zabiegów oferta współpracy (i finansowania przez RKP/REK) została przyjęta.

Dnia 22 marca 1921 r. postanowiono wysłać delegację po pieniądze do Paryża. Delegacja miała być trójczłonowa i składać się z delegatów RKP/REK, rządu ukraińskiego i jeśli to możliwe, $\mathrm{z}$ uprawnionych organizacji z Białorusi, a to w celu: 1) szukania poparcia ze strony rządu francuskiego, oraz 2) zainteresowania bezpartyjnych rosyjskich kręgów finansowych.

Dla potrzeb delegacji postanowiono napisać memorandum:

1) o działalności i stanie RKP/REK,

2) o żydowskich pogromach dokonywanych przez armię generała Bałachowicza i sytuacji, w której podczas ofensywy znajdował się REK w stosunku do wojska,

3) o działalności RKP/REK na pierwszej linii frontu [Protokoły RKP/REK, protokół z posiedzenia 22 marca 1921 r.]. 
Borys Sawinkow nie mógł się wahać. Musiał się odciąć i zdystansować od pogromów żydowskich i innych hańbiących ekscesów, które po prostu nie mogły obciążać jego oddziałów, skoro aplikował o wsparcie bankierów żydowskich. Z jego punktu widzenia należało - dla przyszłości wyśnionej „Trzeciej Rosji” - uprzedzić cios. Jeśliby odium uzasadnionego powszechnego oburzenia spadło i na jego oddziały, nie miałby co liczyć na jakiekolwiek finansowe wsparcie z paryskich banków.

Prawdopodobnie jako pokłosie tej paryskiej akcji wydano w $1921 \mathrm{r}$. drukowane sprawozdanie z działalność RKP/REK w Polsce zatytułowane „V 1920 - VI 1921” (cytowane już przez Leona Grosfelda dla poparcia [sic] zarzutów wobec Bułak-Bałachowicza za zachowanie jego oddziałów w stosunku do Żydów). W moim odczuciu - ten druk odnaleziony przez L. Grosfelda w archiwach holenderskich, a przeze mnie - w Moskwie, był narzędziem ówczesnej przemyślanej rosyjskiej (sawinkowowskiej) polityki informacyjnej.

Autorem broszury najprawdopodobniej był ściśle związany z RKP/REK Wiktor Wiktorowicz Sawinkow (brat Borysa, odpowiedzialny za sprawy wydawnicze, nota bene później mocno zaangażowany w akcję „Wilk”).

Wydarzenia militarne jesieni 1920 r. przedstawiane są w tej broszurze w sposób wybitnie skrótowy. RKP/REK był po prostu zdeterminowany w gwałtownych poszukiwaniach dodatkowych i obfitszych od Piłsudskiego źródeł finansowania. Tym bardziej, iż osoba Piłsudskiego, nie tylko ze względu na fiasko jego polityki wschodniej, ale i ze względu na sytuację na wewnętrznej arenie politycznej w Polsce, nie gwarantowała dalszego dopływu dotacji dla RKP/REK. Udający się wiosną $1921 \mathrm{r}$. $\mathrm{z}$ ramienia RKP/REK do Paryża Sawinkow miał spotkać tam bankierów. Rosyjskich Żydów. Celem pierwszoplanowym Sawinkowa było odbarczenie oddziałów stricte rosyjskich od zarzutu dokonywania pogromów żydowskich, ponieważ sponsorami mieli być właśnie bankierzy żydowscy. A jeśli nadarzała się okazja, by odpowiedzialność za pogromy zrzucić na nielubiane przez Sawinkowa „narzędzie Piłsudskiego” (bo przecież tak właśnie Sawinkow postrzegać musiał Bałachowicza), dowódcę, którego opinię już nadszarpnęli sami Polacy, grzech byłoby nie skorzystać z takiej okazji.

Czytamy w druku „V 1920 - VI 1921” co następuje. „Narodowa Ochotnicza Armia doszła do Dniepru i Mozyrza pozostawiając za sobą pas zgrabionych domostw i słynąc z pogromów Żydów na całej Białorusi” (podkr. JGK). Można się tylko domyślać, jakie emocje w dowódcy Narodowej Ochotniczej Armii - Bułak-Bałachowiczu musiała wzbudzić ta lektura. L. Grosfeld korzystał z egzemplarza „VI 1920 - IX 1921” przechowywanego w Amsterdamie (IIVSG, Archiwum Sawinkowa, t. 16, Polsza 2.) W oparciu o ten właśnie druk z 1921 r. wspierał tezę o tym, iż Sawinkowowi 20 lipca 1920 r. „znana była smutna sława Bałachowicza na odcinku pogromów o grabieży spokojnej ludności" (Grosfeld, 1965, s. 127). Pierwsze meldunki o antysemickich ekscesach „rosyjskich” oddziałów Bałachowicza pojawiły się jesienią $1920 \mathrm{r}$. Ekscesów oddziałów rosyjskich Sawinkowa nigdy nie monitorowano. Abstrahując 
od jednostkowych przypadków niewłaściwych zachowań - ten skrót chronologiczny Grosfelda (seniora) w moim odczuciu zaburza możliwość ustalenia rzeczywistego ciągu przyczynowo-skutkowego wydarzeń na forum publicznym i międzynarodowym.

\section{Reakcja Stanisława Bułak-Bałachowicza}

Stanisław Bułak-Bałachowicz przeciwdziałał akcji zainicjowanej przez RKP/REK, jak potrafil. Stąd seria listów otwartych, z których najistotniejszy (patrz Aneks), jest bardzo mało czytelny przez swoją emocjonalność wynikającą z oburzenia i rozgoryczenia generała, i z tej przyczyny lekceważony przez nielicznych, którzy do niego dotarli.

Bułak-Bałachowicz pisał do Borysa Sawinkowa:

Kadra mojej armii przybyła z Estonii i Łotwy do Polski, jako oddzielny oddział białoruski [sic!] - wniosła ze sobą pewien dobytek wojskowy jako to: konie, wozy, armaty itp. Oddział ten zorganizowany został z ochotników białorusinów, polaków kresowych i rosjan, prześladowanych za swe przekonania polityczne zarówno przez komunistów jak i działaczy tego autoramentu jak Judenicz, Glazenapp, hr. Pallen i inni. Każdy z tych ochotników zniósł pewną część swego mienia do oddziału. Pod względem politycznym kadra ta posiadała swój własny program tzw. „Program Narodowej Armii Ochotniczej” i Korporację antibolszewicką, której członkiem byłem, zatwierdzony w listopadzie $1919 \mathrm{r}$. według którego armia moja działała. Przyjął go Pan [Borysie Wiktorowiczu Sawinkow] jako własny w lipcu r.ub. podczas zawarcia przeze mnie z Panem odpowiedniej umowy. Oddział ten - w odróżnieniu od wszelkich innych formacji - powstałych pod egidą Ros[yjskiego] Kom[itetu] Pol[itycznego] walczył w ciągu 7-u miesięcy bez przerwy na froncie. Zaznaczyć tez muszę, iż kadra ta do chwili przejęcia sądownictwa i kierunku politycznego przez RKP była utrzymywana w rygorze i dyscyplinie wojskowej, oprócz sądów, którym podlegała na terenach państw gdzie walczyła, miała swoje sądy wewnętrzne.

Pod względem finansowym nie korzystała ona żadnych subsydiów ze skarbu polskiego na cele organizacyjne, w odróżnieniu od formacji powstałych pod Pańską [Borysa Sawinkowa] egidą, które za pieniądze ze skarbu polskiego przez cały szereg miesięcy się formowały, a na front $w$ obronie stolicy Polski nie wystąpiły, a jeśli nawet i wyszły pod koniec walk, to połowa ich przeszła na stronę bolszewików, wzniecając dezorganizację i dokonując na rachunek mojej armii rabunki i pogromy, druga zaś połowa na czele z Panem zdradziecko porzuciła mnie w krytycznych chwilach na froncie i uciekła. W dalszym ciągu zaznaczę, iż w odróżnieniu od tych formacji i oddziałów zbrojnych powstałych pod Pańskimi auspicjami, które pierzchły, zdradziecko opuściwszy mnie na froncie $\mathrm{w}$ ciężkich dla mnie chwilach $\mathrm{z}$ Panem na czele, poczem zdały się na łaskę i niełaskę losu - ja w imieniu kadry uświadomiwszy sobie należycie sytuację zarówno polityczną jak i strategiczną, po odpowiednich pertraktacjach z Szefem Sztabu Generalnego (na co posiadam dowody) zgodziłem się złożyć broń i przystałem na czasowe internowanie mojej armii w celu rehabilitacji sponiewieranego przez wrogów imienia mego i mojej armii - na prawach konfinowania, co wg zasad międzynarodowych przysługuje armiom sojuszniczym i na co oddział mój zasłużył, co wywalczył i odpowiednimi umowami jakie zawarował (podk. JGK; całość obszernego listu w Aneksie). 
Zupełnie inną perspektywę spojrzenia na ten etap polityki wschodniej Józefa Piłsudskiego prezentuje przyjaciel Borysa Sawinkowa - Karol Wędziagolski. Po decyzji wydalenia z granic Polski większości członków RKP/REK Wędziagolski pojechał z Sawinkowem do Sejmu i tam „za pomocą swoich osobistych znajomych posłów, niekoniecznie piłsudczyków, spowodowałem prywatne zgromadzenie około stu osób, przed którymi zobrazowałem w skrócie historię i charakter powstania komitetu [RKP/REK], cele i przebieg jego działalności w Polsce, politycznej i wojskowej. O roli Piłsudskiego w tej akcji nie wspomniałem" (Wędziagolski, 2007, s. 439). Jego ocena osoby Stanisława Bułak-Bałachowicza również jest odmienna od tej, która wynika z prezentowanych tu dokumentów. „Jest to typowy partyzant i warchoł, raczej doskonały ataman rozbójników niż oficer w europejskim stylu, lecz w warunkach tej wojny niezrównany dowódca. Bije bolszewików w wielu wypadkach lepiej niż sztabowi generałowie, bo sam jest bolszewikiem [sic! - JGK], zresztą genealogicznie się z nich wywodzi” (Wędziagolski, 2007, s. 434). Józef Mackiewicz pisze „W roku 1920 została utworzona rosyjska organizacja wojskowa /gen. Peremykin, Głazienap, hr. Pahlen/. Rosyjskie formacje po stronie Polski osiągnęły stan 80.000, włączono do nich oddziały Bułak-Bałachowicza i esauła Jakowlewa" (Mackiewicz, b.d.).

Wsparcia ostatecznie udzielił Bułak-Bałachowiczowi Lis-Błoński. W opozycji do „czarnego PR” z epoki, po kilku latach Lis-Błoński relacjonował wprost idylliczny obraz sytuacji (w Kamieniu Koszyrskim). Wkraczającego do miasta Bułak-Bałachowicza chlebem i solą miała powitać na rogatkach starszyzna żydowska. Po wjeździe do miasta ukazać się miał Bałachowiczowi widok rozpaczliwy. Przejęty i wstrząśnięty Bułak-Bałachowicz natychmiast miał udzielić pomocy poszkodowanym (nie bez znaczenia jest fakt, iż Lis-Błoński odnotował wypadki współdziałania w tym mieście z wojskami sowieckimi koszyrskiej młodzieży żydowskiej, z których kilkaset osób usunęło się wraz z wycofującymi się oddziałami sowieckimi). W wyniku interpelacji powołano sejmową komisję śledczą, złożoną - co Lis-Błoński podkreśla - z ludzi nieprzychylnych Bałachowiczowi. Winy oddziałom Bałachowicza nie udało się członkom tej komisji jednak udowodnić, a podejrzenie skierowano ostatecznie na partię powstańców z Pińszczyzny operującą na tyłach wojsk bolszewickich. (Sam Bułak-Bałachowicz winą za dokonanie prowokacyjnego pogromu w Kamieniu Koszyrskim obciążył niejakiego pułkownika Barskiego vel Beszela, adiutanta Gustava von der Goltza. Patrz Aneks k. 19 oryginału).

Wszystko wskazuje na to, że Bałachowicz, znakomity wojskowy, ale nader mierny polityk, uznał poparcie Piłsudskiego dla Sawinkowa i swoje podporządkowanie się tej koncepcji za swój własny błąd polityczny. Po klęsce akcji mozyrskiej, z kolei Sawinkow zaczął personalnie obwiniać wyłącznie Bułak-Bałachowicza za pogromy ludności żydowskiej, co sprawić musiało, iż w sposób niezasłużony, Baćka znalazł się w roli kozła ofiarnego. Z kolei Bułak-Bałachowicz postrzegał Sawinkowa jako polityka konsekwentnie współdziałającego z Głazenappem i Bredowem na niekorzyść Polski i nie rozumiał przyczyn życzliwości dla RKP/REK okazywanej przez Piłsudskiego. 
Komentując tezy obszernego listu otwartego Bułak-Bałachowicza do Borysa Sawinkowa (w Aneksie) trzeba stwierdzić, że armia generała Bredowa istotnie nie wzięła udziału w walkach. Oddziały rosyjskie wyszły jednak w pole w lecie $1920 \mathrm{r}$. Sam Sawinkow - wbrew temu, co mu zarzucał Bałachowicz - walczył w Konnym Pułku Armii Ochotniczej [„VI 1920 - IX 1921”].

Autorzy odnalezionego przez L. Grosfelda w Amsterdamie oraz ostatnio, przeze mnie w Moskwie opracowania RKP/REK [„VI 1920 - IX 1921”] - wbrew powszechnej opinii, jako „słabe” określili - oddziały ukraiński i białoruski. Warto może jeszcze dodać, że według tego źródła naczelnikami sztabów byli wyłącznie oficerowie powiązani z organizacjami monarchistycznymi w Berlinie. Tylko ten ostatni fakt znajduje pewne potwierdzenie w ustaleniach J. Gierowskiej-Kałłaur (2015b oraz inne, jeszcze niepublikowane materiały odnalezione przez nią w Moskwie).

O ustaleniach pomiędzy członkami RKP/REK czy o działalności Sawinkowa w Paryżu Bułak-Bałachowicz po prostu nie mógł wiedzieć. Jednak informacja o książeczce „V 1920 - VI 1921”, prawdopodobnie drukowanej za polskie pieniądze, musiała trafić do jego rąk i po prostu przelać czarę goryczy. On i jego ludzie zostali wskazani przez RKP/REK jako jedyni odpowiedzialny za wszystkie antyżydowskie ekscesy, a - tym samym - w jakiś sposób oskarżano państwo polskie, $\mathrm{z}$ którym Bułak-Bałachowicza na arenie międzynarodowej identyfikowano w 1921 r. już powszechnie, a na którego utrzymaniu znajdowali się ci jego żołnierze, którzy pozostali mu wierni, ignorując oferty wysłanników Sawinkowa, werbujących ich do dalszej walki - tym razem oficjalnie wyłącznie za Rosję (nieważne którą).

Wiele się zmieniło. Bułak-Bałachowicz nie reprezentował już „terenowej” przynależności. Projekt reaktywowania byłej Rzeczypospolitej Obojga Narodów w postaci federacji jej dawnych części składowych stracił ostatnią szansę na realizację. Bułak-Bałachowicz i ,jego" ludzie znaleźli się w nader niekomfortowej (i moralnie, i ekonomicznie) sytuacji. Dług wdzięczności wobec nich powinien mieć ich sprzymierzeniec - Polska. I tutaj pojawił się problem. „Polska” realizowała w tym czasie linię polityczną obozu przeciwstawnego do linii polityki tych, z którymi się Bułak-Bałachowicz sprzymierzył, i z którymi razem - przegrał. Zdawał sobie jednak sprawę, że z Polską go utożsamiano, i nie zważał na krążące po salonach plotki - i te o świadectwach białoruskości wydawanych mu w swoim czasie przez Jezowitowa, i te o uszczypliwych, a nader chętnie cytowanych, uwagach Józefa Piłsudskiego na temat zmiennej narodowej tożsamości, kierowane pod adresem generała. Dystansując się od żartów, również i tych $\mathrm{z}$ epoki, wydaje mi się, że generał sam dobrze wiedział, kim jest, a kim nie jest. Czuł więź z różnorodnymi mieszkańcami swojego kraju, który rozciągał się dla niego od Bałtyku do Kaukazu. W nowych pokojowych warunkach trzeba było jednak stanąć na straży interesów tych, którzy mu zaufali. Więc „został Polakiem”, bo tylko w ten sposób był w stanie cokolwiek od NDWP dla swoich ludzi wyegzekwować. W liście do płk. Rudolfa napisał: „Polityka gorsza 
od wojny" [CAW, sygn. I.480.72, k. 13-21]. Piłsudskiego darzył jednak szacunkiem i czcią do końca swoich dni.

\section{Postscriptum}

Józef Piłsudski wiedział o poczynaniach Sawinkowa i wspierał go swą radą (i dotacjami) do lata 1921 r., do chwili rozpowszechnienia listu otwartego Stanisława Bułak-Bałachowicza do Borysa Sawinkowa z sierpnia 1921 r. Czy to przypadkowa zbieżność?

\section{ANEKS}

\section{I}

\section{Stanisław Bułak-Bałachowicz o sobie}

LCVA, Fond 281, opis 1, teczka 12, k. 1-11 [odpis z adnotacjami odręcznymi] Listu otwartego Generała Bułak-Bałachowicza do Sejmu Ustawodawczego Rzeczypospolitej Polskiej, w którym czytamy m.in.:

Jestem demokratą, Synem ludu. Chrześcijaninem-katolikiem. Św[iętej] p[amięci] matka moja była Polką, ojciec jest-Białorusinem. Jestem ponad partjami. Przybyłem do Polski jako generał białoruski, dobrowolnie z oddziałem przezemnie zorganizowanym, uzbrojonym i wyekwipowanym. Kadra mej armji składała się z Białorusinów, Polaków kresowych i Rosjan, prześladowanych za swe przekonania przez komunistów i germanofilów. Garnęły się do mnie zawsze chętnie i ofiarnie wszelkie żywioły antykomunistyczne. $\mathrm{W}$ wojsku byłem żołnierzem, a jako taki-apolitycznym. Miałem i mam gorącą wiarę w Boga i sprawiedliwość. W roku 1918 mając, jako godło na swym sztandarze - krzyż, w przeciwstawieniu do gwiazdy sowieckiej, podjąłem nierówną walkę w obronie uciśnionych ludów. Walczyłem skutecznie za wolność Estonji, tej Rosji, która chciała pozostać chrześcijańską i szczerze demokratyczną, następnie Łotwy, Polski i Białej Rusi (fragment z k. 10-11).

LCVA, Fond 281, opis 1, teczka 12, k. 33-34v [Uwiarygodniony przez St. Bułak-Bałachowicza odpis] Stanisław Bułak-Bałachowicza Do Pana Ministra Spraw Zagranicznych, Nr 507 z dn. 8 VII 1921.

LCVA, Fond 281, opis 1, teczka 12, k. 35-40 [Uwiarygodniony przez St. Bułak-Bałachowicza odpis] [Listu] Do J. W. Pana Sikorskiego jenerała porucznika szefa Sztabu Generalnego, Warszawa 3 Maj 1921. [Bałachowicz pisze o sobie jako o dowódcy wszystkich oddziałów zbrojnych na terytorium Białej Rusi]:

Nadmienię, iż będąc po matce Polakiem, po ojcu zaś - Białorusinem, dla korzyści sprawy dowodziłem dywizją i armją rosyjsko-białoruską, gdyż posiadając w Rosji i na 
Białej Rusi imię popularne większą tym sposobem szkodę bolszewikom, Polsce zaś pożytek przynieść mogłem. [---] przyjmowałem do siebie, a nawet posługiwałem się ludźmi podejrzanej wartości moralnej. Umiałem ich jednak utrzymać w rygorze i posłuszeństwie. Udawało mi się niejednokrotnie tę miazgę ludzką na bohaterów przerobić. Jeśli celu zamierzonego nie osiągnąłem, tępiłem element szkodliwy [--] Ros[yjski] Kom[itet] Polit[yczny] wybiera z mojej b[yłej] armji najniżej stojący moralnie element oficerski i żołnierski, taki, którego nie należałoby puścić samopas, zabiega aby go uwolnić z za drutów, asygnuje mu pieniądze i wysyła na front, polecając mu aranżować partyzantki na kresach pod moją firmą. $Z$ drugiej zaś strony tenże Komitet przyczynia się do rozpowszechniania broszur i wiadomości dyskredytujących moje dobre imię. Zmusiwszy mnie [sic] do odsunięcia się od formacji białoruskich rozmyślnie przedstawia mnie jako moskala i reakcjonistę przed lewicą w Polsce, podszczuwa rozmyślnie żydów, rozpowszechniając o mnie różne niedorzeczne brednie, przed prawicą zaś usiłuje zarekomendować mnie jako pół-bolszewika [--] Ukrytą bowiem tendencją Sawinkowa i jego kliki jest uczynić ze mnie potulnego konika, na którymby dzięki mojej popularności - jeździły ich cele i ambicje [--] W dalszym ciągu zaznaczam, iż dziś [--] mógłbym być pożytecznym dla sprawy białoruskiej [--] dokonać bezpośrednio dzieła niepodległości Białej Rusi pośrednio zaś dla Rzeczypospolitej Polskiej czynów bardziej pożytecznych (fragment z k. 37v-38-38v).

\section{II}
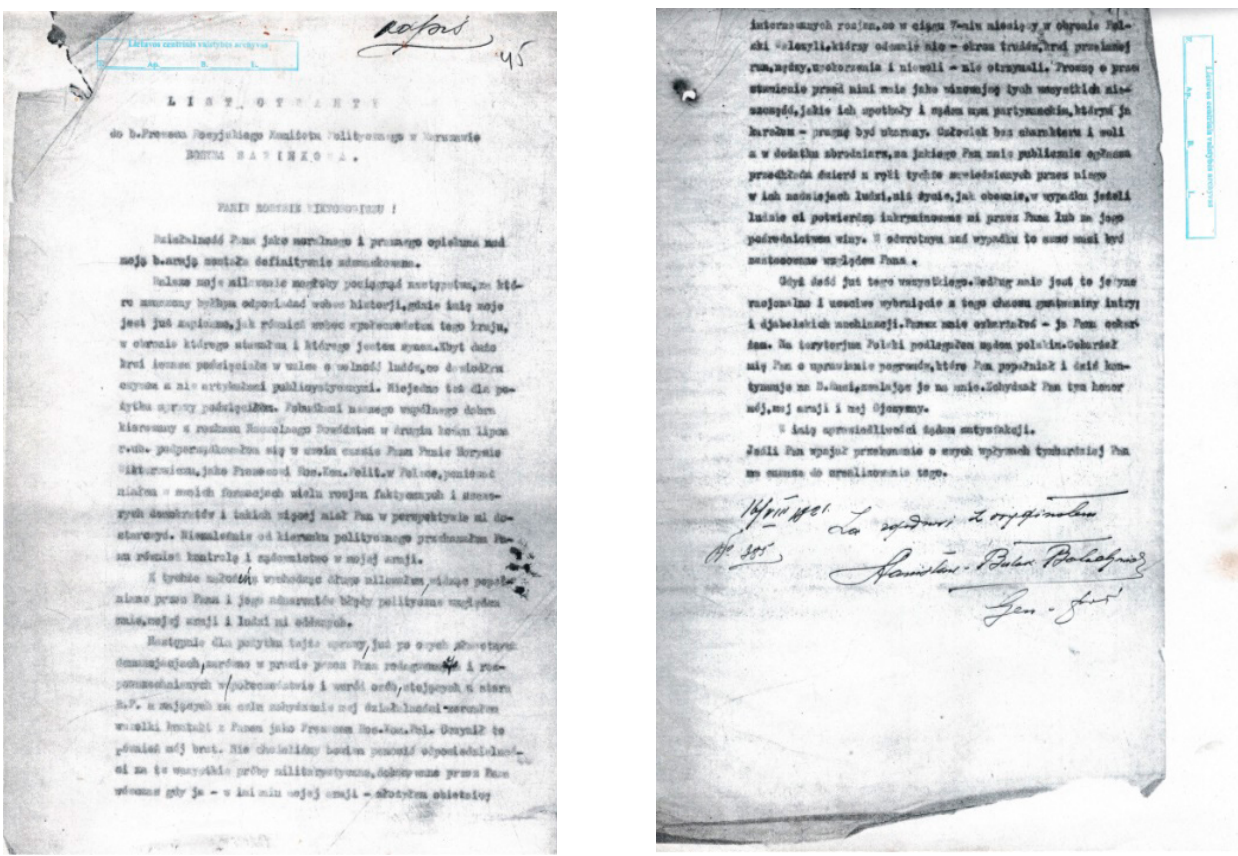
Pierwsza i ostatnia strona Listu otwartego Stanisława Bułak-Bałachowicza. Do b. Prezesa Rosyjskiego Komitetu Politycznego w Warszawie Borysa Wiktorowicza Sawinkowa. Uwiarygodniony przez Stanisława Bułak-Bałachowicza odpis przechowywany jest w Wilnie, w Lietuvos Centrinis Valstybès Archyvas, Fond 281, opis 1, teczka 12, k. 45-71.

\section{LIST OTWARTY ${ }^{2}$ \\ Do b. Prezesa Rosyjskiego Komitetu Politycznego w Warszawie Borysa S AWINKOWA}

\section{PANIE BORYSIE WIKTOROWICZU !}

Działalność Pana jako moralnego i prawnego opiekuna nad moją b. armią została definitywnie zdemaskowana.

Dalsze moje milczenie mogłoby pociągnąć następstwa, za które zmuszony byłbym odpowiadać wobec historii, gdzie imię moje jest już zapisane, jak również wobec społeczeństwa tego kraju, w obronie którego stawałem i którego jestem synem. Zbyt dużo krwi i czasu poświęciłem w walce o wolność ludów, co dowiodłem czynem a nie artykułami publicystycznymi. Niejed no też dla pożytku sprawy poświęciłem. Pobudkami naszego wspólnego dobra kierowany z rozkazu Naczelnego Dowództwa w drugim końcu lipca r.ub. podporządkowałem się w swoim czasie Panu Panie Borysie Wiktorowiczu, jako Prezesowi Ros[yjskiego] Kom[itetu] Polit[ycznego] w Polsce, ponieważ miałem w moich formacjach wielu rosjan faktycznych i szczerych demokratów i takich więcej miał Pan w perspektywie mi dostarczyć. Niezależnie od kierunku politycznego przekazałem Panu również kontrolę i sądownictwo w mojej armii.

Z tychże założeń wychodząc długo milczałem, widząc popełniane przez Pana błędy polityczne względem mnie, mojej armii i ludzi mi oddanych.

Następnie dla pożytku tejże sprawy, już po owych sławetnych denuncjacjach, zarówno w prasie przez Pana redagowanych i rozpowszechnianych w społeczeństwie i wśród osób, stojących u steru R. P. , a mających za cele zohydzenie mej działalności zerwałem wszelki kontakt z Panem jako Prezesem Ros[yjskiego]. Uczynił to również mój brat. Nie chcieliśmy bowiem ponosić odpowiedzialności za te wszystkie próby militarystyczne, dokonywane przez Pana wówczas gdy ja - w imieniu mojej armii złożyłem obietnicę

${ }^{2}$ Maszynopis, kolejna (bardzo wypłowiała) kopia z kopii na źle zachowanej (miejscami porwanej) przebitce, ostatnia strona - podpis oryginalny Stanisława Bułak-Bałachowicza. W tekście zachowano oryginalną pisownię, literówki, ubytki logiczne wątku. Zachowano także oryginalną pisownię dużych i małych liter, stosowaną w epoce. 


\section{k. 2 listu (k. $46 \mathrm{w}$ teczce)}

lojalnego zachowywania się względem Rzeczp[pospolitej] Polskiej - solidnie wykonywałem wszystkie me zobowiązania i zgodziłem się nawet na internowanie mej armji mając głównie na względzie eliminację elementu zbrodniczego i zdemaskowanie prowokatorów co już w grudniu przedstawicielowi prasy oświadczyłem. Sam osobiście usunąłem się dobrowolnie czasowo [sic] od kierownictwa armją.

1) ze względu na kurację po ranach otrzymanych na froncie,

2) aby nie dać powodów R. P. do jakowych komplikacji politycznych.

Zaiste w bardzo kłopotliwej znalazłem się sytuacji. Miałem wprawdzie kilka wyjść. Nie przedstawiało jednak dla mnie żadnego uroku prowadzenie za przykładem Pana podstępnej pracy, polegającej na denuncjacjach i kolportowaniu doniesień celem urabiania opinii i stwarzania odpowiednich nastrojów wśród władz w kierunku dla siebie pożądanym. Co zaś dotyczy moich wystąpień w prasie, to odniosłyby one jedynie ten skutek, iż materiał ponownie użyty zostałby przez wrogów, przez co zaszkodziłbym tylko sprawie, za którą walczyłem i przyniósłbym pośrednio szkodę Rzeczp[pospolitej] Polskiej. Milczenie zaś moje mogłoby być znowu poczytywane jako cicha współpraca, a nawet współuczestnictwo w przeprowadzaniu rozmaitych Pana machinacji politycznych lub usprawiedliwiałaby Pana twierdzenia. Ponieważ przestrogi moje skierowane do Pana i żądania zaprzestania kontynuacji rozmaitych ${ }^{a}$ sztuczek politycznych skutku pożądanego nie odniosły - wybrałem przeto drogę - jasnego zwrócenia się do Pana listem otwartym, przesyłając go w odpisach osobom w tej sprawie zainteresowanym i cieszącym się mem zaufaniem, których losy Rzeczp[pospolitej] Polskiej jak również tragiczna dola mej armii obchodzą i obchodzić muszą z uwagi na jej przeszłą działalność i rolę, jaką, ewentualnie, może ona odegrać w przyszłej akcji przeciwko wrogom. Mam również w danym wypadku na widoku zabezpieczenie jej od wpływów zgubnej polityki wprowadzającej w demokratyczny ustrój tej mocnej i zdecydowanej antibolszewickiej i przeciwniemieckiej jednostki bojowej gangrenę moralną.

Stosownie do mych zasad partyzanckich uprzednio 2-krotnie na zebraniach jako też piśmiennie przestrzegałem Pana - skutku to nie odniosło, obecnie więc zmuszony jestem oddać ostatecznie sprawę moją z Panem w ręce przedstawicieli Rządu Polskiego, który

\section{k. 3 listu (k. 47 w teczce)}

mylnie dotychczas przez Pana informowany nie zbadał istoty sprawy należycie i nie położył kresu Pańskim rzekomo politycznym a sprzyjającym jakoby interesom Rzeczp[pospolitej] Polskiej eksperymentom militarnym, co faktycznie było i jest na rękę jedynie Niemcom i bolszewikom.

a Słowo w oryginalnym tekście zaiksowane maszynowo w sposób nieczytelny, nad nim maszynowo nadpisane: „rozmaitych”. 
Jako syn ludu i obywatel Rzecz[pospolitej] Polskiej, dla obrony której przyprowadziłem ze sobą dla wspólnej walki przeciwko bolszewikom oddział, stanowiący kadrę mojej armii, mam dziś prawo domagać się na podstawie mej umowy zawartej dn. 23 II 1920 z Rządem Polskim wyeliminowania mej armii z pod wpływów i rządów Pana i zażądać też odpowiedniego rozrachunku.

Przy niniejszym przypominam, że kadra mojej armii przybyła z Estonii i Łotwy do Polski, jako oddzielny oddział białoruski - wniosła ze sobą pewien dobytek wojskowy jako to: konie, wozy, armaty itp. Oddział ten zorganizowany został z ochotników białorusinów, polaków kresowych i rosjan prześladowanych za swe przekonania polityczne zarówno przez komunistów jak i działaczy tego autoramentu jak Judenicz ${ }^{3}$, Glazenapp ${ }^{4}$, hr. Pallen ${ }^{5}$ i inni. Każdy z tych ochotników zniósł pewną część swego mienia do oddziału. Pod względem politycznym kadra ta posiadała swój własny program tzw. „Program Narodowej Armii Ochotniczej” i Korporację antibolszewicką, której członkiem byłem, zatwierdzony w listopadzie 1919 r. według którego armia moja działała. Przyjął go Pan jako własny w lipcu r. ub. podczas zawarcia przeze mnie z Panem odpowiedniej umowy ${ }^{6}$. Oddział ten - w odróżnieniu od wszelkich innych

${ }^{3}$ Judenicz Nikołaj Nikołajewicz (1862-1933). Główną bazą działalności był Psków. Priorytetowym i nigdy nieosiągniętym celem było zdobycie Piotrogrodu. Naczelny wódz Białej Armii Północno-Zachodniej (2 X - 29 listopada 1919 r.). Od około 1919 r. na terytorium Estonii, która w celu oszczędzenia własnego terytorium w obawie przed wkroczeniem bolszewików wymówiła Judeniczowi gościnę. Zagrożony rozbrojeniem swoich oddziałów Judenicz pośpiesznie zorganizował atak na Piotrogród i Psków, jego oddziały zostały jednak odrzucone i przygwożdżone do granicy estońskiej. Od masakry uratowała ich brytyjska flota. W styczniu 1920 r. aresztowany przez gen. majora Stanisława Bułak-Bałachowicza. Zwolniony, udał się na emigrację do Francji.

${ }^{4}$ Głazenap Piotr Władimirowicz (1882-1951). Generał-lejtnant. W 1915 r. zorganizował i wykonał słynny nocny rajd na niemieckie tyły. Awansowany do stopnia podpułkownika dowodził samodzielnym oddziałem uderzeniowym. W czasie wojny domowej w trakcie pierwszego marszu kubańskiego („Ledianogo") dowodził dywizją. Następnie Korniłow wyznaczył go na dowódcę pułku kawalerii. W trakcie drugiego kubańskiego marszu zajmował stanowisko generała-gubernatora guberni stawropolskiej. W 1919 r. został odkomenderowany do dyspozycji gen. Judenicza. Awansowany przez niego do stopnia generał-lejtnanta objął stanowisko gubernatora Piotrogrodu. Pełnił funkcję generał-gubernatora ziem okupowanych przez Północno-Zachodnią Armię. Po klęsce marszu na Piotrogród przystąpił w $1920 \mathrm{r}$. w Polsce do formowania tzw. Trzeciej Armii Rosyjskiej na terytorium Polski. W początkach emigracji żył w Budapeszcie, w 1922 r. - w Niemczech, w 1925 r. - w Gdańsku. Założył w Gdańsku organizację dla dywersji i ewentualnego wywiadu przeciw Sowieckiej Rosji. Żona - Maria Stanisławowa Głazenap $\mathrm{z}$ domu grafinia Borż w trakcie I wojny światowej była siostrą miłosierdzia, brała udział w wojnie domowej jako koordynatorka pracy wywiadowców.

${ }^{5}$ Pahlen Aleksiej Piotrowicz (1874-1938), rosyjski lejtnant-generał, oficer białorosyjski Nikołaja Nikołajewicza Judenicza. W roku 1921 i później członek „Sojuszu Bałtijskich Dworian” o ściśle monarchistycznych tendencjach, któremu przyświecał cel odzyskania prowincji bałtyckich dla Rosji. Czołowymi przedstawicielami tej grupy oprócz Pahlena byli: Mejendorf, Mannteufel, Helvin, gen. Gühnl, ks. Krapotkin, hrabia Grabbe, Adlerberg, von Volkersahm.

${ }^{6}$ Dnia 28 czerwca 1920 r. Sawinkow zawarł umowę z przedstawicielem oddziałów rosyjskich, przebywających na granicy Łotwy i gubernii pskowskiej i witebskiej pod dowództwem gen. hr. Pahlena, 
formacji - powstałych pod egidą Ros[yjskiego] Kom[itetu] Pol[itycznego] walczył w ciągu 7-u miesięcy bez przerwy na froncie. Zaznaczyć też muszę, iż kadra ta do chwili przejęcia sądownictwa i kierunku politycznego przez R[osyjski] K[omitet] $\mathrm{P}$ [olityczny] była utrzymywana w rygorze i dyscyplinie wojskowej, oprócz sądów, którym podlegała na terenach państw gdzie walczyła, miała swoje sądy wewnętrzne. Pod względem finansowym nie korzystała ona żadnych subsydiów ze skarbu polskiego na cele organizacyjne, w odróżnieniu od formacji powstałych pod Pańską egidą, które za pieniądze ze skarbu polskiego przez cały szereg miesięcy się formowały, a na front w obronie stolicy Polski nie wystąpiły, a jeśli nawet i wyszły pod koniec walk, to połowa ich przeszła na stronę bolszewików, wzniecając dezorganizację i dokonując na rachunek mojej armii rabunki i pogromy, druga zaś połowa na czele

\section{k. 4 listu (k. 48 w teczce)}

z Panem zdradziecko porzuciła mnie w krytycznych chwilach na froncie i uciekła.

W dalszym ciągu zaznaczę, iż w odróżnieniu od tych formacji i oddziałów zbrojnych powstałych pod Pańskimi auspicjami, które pierzchły, zdradziecko opuściwszy mnie na froncie w ciężkich dla mnie chwilach z Panem na czele, poczem zdały się na łaskę i niełaskę losu - ja w imieniu kadry uświadomiwszy sobie należycie sytuację zarówno polityczną jak i strategiczną po odpowiednich pertraktacjach z Szefem Sztabu Generalnego $^{7}$ (na co posiadam dowody) zgodziłem się złożyć broń i przystałem na czasowe internowanie mojej armii w celu rehabilitacji sponiewieranego przez wrogów imienia mego i mojej armii - na prawach konfinowania, co wg zasad międzynarodowych przysługuje armiom sojuszniczym i na co oddział mój zasłużył, co wywalczył i odpowiednimi umowami jakie zawarował.

Byłem pewny, że po przekazaniu opieki nad moją armią instytucji tego rodzaju, co R[osyjski] K[omitet] P[olityczny] zostanie wyeliminowany bezstronnie z pośród

\footnotetext{
w sprawie podporządkowania politycznego tych oddziałów sobie. Dnia 7 lipca 1920 r. Sawinkow zawarł umowę z gen. Głazenappem, na podstawie której ten objął dowództwo Specjalnego Oddziału Rosyjskiego, który „działa w ścisłym moralnym związku z gen. Wranglem, ale chwilowo na zasadzie autonomii”. W sprawach politycznych i dyplomatycznych ostatnie słowo miało należeć do Sawinkowa. Zgodnie z umową z 7 lipca 1920 r. B. Sawinkow, D. Fiłosofow i gen. Glazenapp utworzyli nieoficjalny komitet organizacyjny dla realizacji tychże postulatów, zarówno politycznych, jak i dyplomatycznych. Dnia 20 lipca 1920 r. doszło do spotkania Bułak-Bałachowicza z Borysem Sawinkowem. Dla Sawinkowa Stanisław Bułak-Bałachowicz był byłym współpracownikiem gen. Judenicza. Generał Bałachowicz - nie bez presji wywieranej przez Naczelnego Wodza - wyraził gotowość podporządkowania siebie i swojego oddziału Rosyjskiemu Komitetowi Politycznemu. W końcu sierpnia 1920 r. z rozkazu Naczelnego Dowództwa Bułak-Bałachowicz zawarł z Sawinkowem umowę, której kolejny egzemplarz odnalazł w aktach Naczelnego Wodza w Instytucie Józefa Piłsudskiego w Nowym Yorku M. Cabanowski. L. Grosfeld korzystał z egzemplarza przechowywanego w IISVG, Archiwum Sawinkowa, r. 16, Polsza 2.

${ }^{7}$ Szefem Sztabu był od 22 lipca 1920 r. do 1 kwietnia 1921 r. gen. por. Tadeusz Rozwadowski.
} 
internowanych element zbrodniczy, który się tam zakradł dzięki wrogiej prowokacji i systemowi armii ochotniczej - ludzie zaś zasłużeni zostaną odpowiednio wynagrodzeni i według zasad międzynarodowych będą zwolnieni z obozów, użyci do pracy pokojowej i wykorzystani umiejętnie dla kraju, w obronie którego krew przelewali zgodnie z mym planem przedstawionym już w grudniu r. ub.

Okazało się jednak, że opieka R[osyjskiego] K[omitetu] P[olitycznego] była skierowana na tory niewłaściwe, wskutek czego egzystencja ludzi nawet zasłużonych stała się nieznośną.

Okazało się, iż ludzie, którzy w ciągu całego szeregu miesięcy z zaparciem się siebie na froncie walczyli są - dzięki stosowanej względem nich przewrotnej polityce $\mathrm{R}$ [osyjskiego] K[omitetu] P[olitycznego] rozgoryczeni, a nawet usiłowano usposobić ich wrogo do tego kraju i społeczeństwa, w obronie którego walczyli. Czynione jest to z rozmysłem na korzyść wrogów. Sytuacja taka dalej trwać nie może. Zarówno siebie, jak i Pana zmuszony jestem zawezwać na sąd tak władz polskich, jak i mojej kadry, która dzięki nieostrożności popełnionej przeze mnie względem Pana, do którego miałem dane mieć - po otrzymaniu odpowiednich wskazówek - zaufanie, pozostawała w położeniu nad wyraz ciężkim, jest maltretowana i nadal pchaną przez Pana świadomie na rozmai ${ }^{b}$

\section{k. 5 listu (k. 49 w teczce)}

ryzykowne przedsięwzięcia, na które ja nie tylko nie dałem aprobaty, ale kategorycznie je zwalczam.

W dalszym ciągu wyliczę Panu bardziej pryncypjalnie niekonsekwencje, które Pan popełnił od chwili objęcia kurateli nad moją armią. Oto są:

1) ${ }^{c}$ Demoralizacja armii ${ }^{c}$ (Asygnowanie bez mojej wiedzy milionowych sum moim podwładnym, co miało miejsce w Lublinie z pułk Mikoszą, pułk. Duchopilnikowym i innymi, a co właśnie wniosło dezorganizację w szeregi armii)

2) Bezczynność kontroli R[osyjskiego] K[omitetu] P[olitycznego] co doprowadziło do zaniedbania rachunkowości - następnie zaś oskarżono osoby, które istotnie były temu winne, ale ich nie ukarano.

Jednocześnie po internowaniu armii byłem pewny, ze każdy z nas błędy swe nie tylko zrozumie, ale nie zechce ich też wykorzystywać na szkodę drugiego, co ew[identnie] odbiło się zawsze na istotach niewinnych, a co ważniejsze nie przynosi to żadnego pożytku sprawie, za którą wszak wspólnie walczyliśmy. Powtarza się obecnie znów fakt znamienny: zamiast ukarać winowajców, główni właśnie sprawcy pogromów i rabunków są przez Pana wypuszczeni zza drutów, subsydiowani, ułatwiany im jest przejazd na Białoruś jak również przyjazd zza frontu oraz egzystencja w Warszawie. Aranżowanie przez nich partyzantki naraża Rząd Polski na straty i zatargi z Sowie-

${ }^{b}$ Dalej nieodbity tekst ostatniego wersu na stronie; ${ }^{c-c}$ Podkreślenie Stanisława Bułak-Bałachowicza. 
tami, burzy to umysły, powoduje niesłuszne represje względem ludzi zasłużonych i stawia mnie w pozycji fałszywej, prawie bez wyjścia.

Zapytuję, kto Panu dał prawo do tego rodzaju eksperymentów?

Żyjemy w czasach politycznie i ekonomicznie ciężkich, gdzie każdy nasz fałszywy lub nierozważny krok przynieść może, a niejeden nawet już przyniósł, nieobliczalne straty. Kategorycznie żądam zaprzestania prowadzenia tego rodzaju prowokacyjnej polityki z moimi ludźmi.

Zastrzegłem się w swoim czasie, że wojna partyzancka jest skończona. Nie powinno się iść na rękę wrogom. Pan tego w swoim czasie nie zrozumiał i dziś Pan tego pojąć nie jest w stanie. Wciąga Pan kraj w jakieś powikłania, których ani sensu, ani istoty, ani skutków Pan nie przecenia ani nie rozumie. Oszukuje Pan Rząd Polski, oszukuje Pan ludzi, czyni pan wyzysk, za co ludzie krwią płacą i działa Pan jedynie na korzyść ${ }^{d}$ bolszewików i Niemców co pierwszym ${ }^{d}$

\section{k. 6 listu (k. $50 \mathrm{w}$ teczce)}

pozwala ogałacać kraj i znęcać się nad ludnością - drugim zaś ułatwia Pan realizację ich planu ubiegłej wiosny, który przecież nie jest Panu obcy.

Deprawuje Pan element zdrowy i ideowy z pośród mojej armii, który chciałby i powinien zająć się pracą spokojną, do czego ja usilnie dążyłem i dążę. Nęci Pan pokusą szerokich perspektyw politycznych różne zapalczywe i niedowarzone głowy, które w następstwie padają ofiarą Pańskiej polityki.

Z pomocą swych agentów usiłuje Pan wmówić w moich ludzi, że zostałem usunięty od armii za szkodliwą politykę. Względem zaś tych, co nie dadzą się Panu wodzić za nos stosuje Pan represje, nadużywając swojej władzy, co miało miejsce w obozie w Pikuliczach [Pikulicach], skąd kilkadziesiąt ludzi dzięki Pana machinacjom zostało odesłanych do Dąbia, co wrogo usposabia pozostałych internowanych względem administracji polskiej.

Ostatnimi czasy wielu ich ucieka z obozów - co jest faktem, przybywają do mnie ze skargami, pozbawieni częstokroć odzieży i obuwia, gdy tymczasem notoryczni przestępcy są przy pomocy Pana wypuszczeni zza drutów i wspomagani pieniężnie na cele pogromów i zbrodni, które jak zwykle idą znów na mój rachunek i których echa odbijają się nawet w prasie francuskiej, co skrupulatnie powtarza prasa polska. Przestępcami tymi są: b[yli] pułk[ownicy] Pawłowski, Pawłow, Andrejew, Ertman, Wojciechowski. Z nich Pawłowski, Pawłow i Wojciechowski za popełnione poprzednio zbrodnie winni być oddani pod sąd, dziś zaś kontynuują oni pod Pana autorytetem i przy jego poparciu materjalnem swą robotę.

$d^{-d}$ Nie odbiło się i jest dopisane ręką Stanisława Bułak-Bałachowicza.

${ }^{8}$ Zob. Gierowska-Kałłaur (2015b). 
Powyżej wspomniani po dokonaniu pogromów na mój rachunek, są obecnie w Warszawie. Pawłowski, pod nazwiskiem Sujewskiego zamieszkuje w hotelu „Sport”, Pawłow w hotelu Kowieńskim, Wojciechowski również po pogromach dokonanych w okolicy Kopatkowicz przybył na występy do Warszawy. Korszunow, którego za zbrodnie chciałem rozstrzelać, dzięki poparciu Pana, pod przybranym nazwiskiem, wyjechał do Wilna - został jednak aresztowany i będzie oddany pod sąd.

W dalszym ciągu podkreślam: ponieważ Pan, wstępując do mojej organizacji, dobrowolnie przyjął program mojej Armii Ochotniczej, ektóry przewiduje w sądownictwie jednakowy wymiar kary dla wszystkich ${ }^{e}$

\section{k. 7 listu (k. $51 \mathrm{w}$ teczce)}

wszystkich ${ }^{f}$ członków organizacji, dopuszczających się czynów występnych, więc moralnie podlega Pan temu sądowi za swą działalność prowokacyjną.

Na podstawie zaś dowiedzionych faktów, a stwierdzonych przez świadków, ja - jako przewodniczący Związku Partyzanckiego aktem sporządzonym w dniu 28 lipca br zaopiniowałem wydalenie Pana Panie Borysie Wiktorowiczu na równi z kilkoma innymi osobami, skompromitowanymi, z naszego Związku, który Pan działalnością swą zohydził. Gdyby mi chodziło - że tak powiem - o własną moją osobę, to doprawdy nie miałbym $\mathrm{w}$ danym wypadku kłopotu, załatwiłbym z Panem sprawę po familijnemu. Sprawa jest jednak stokroć poważniejsza. Chodzi o egzystencję, reputację i byt kilku tysięcy zasłużonych, uczciwych i dzielnych ludzi, których po 3-letniej krwawej i uciążliwej wojnie chciałem ze względu na okoliczności zatrudnić, aby na polu pracy mogli być też użytecznymi, a Pan stale mi uniemożliwiał i pod rożnymi pretekstami nadal uniemożliwia.

Stawiam sprawę jasno. Dla celów Pana chwilowo potrzebni są zbóje. Weź ich Pan wszystkich. Mnie obecnie potrzebni są ludzie pracy, ew[entualnie] ci, w których tkwią, chociażby w jak najmniejszym stopniu, pierwiastki ładu, porządku i zamiłowania do pracy. [W] armii mojej ze zbójami załatwiałam się krótko, o czem zaświadczyć mogą odpowiednie akta i rozkazy.

Zaznaczyć muszę, iż ręka Pana w tym kierunku była bardziej aksamitna i przewrotna. Pan ich rozpuścił i zdemoralizował, obecnie zaś popiera ich do celów swej polityki.

Nie poruszałbym w ogóle tej kwestii, gdybym względem uczciwej i dzielnej reszty tych ludzi nie miał pewnych moralnych, a nawet prawnych zobowiązań. Dowiaduję się również, iż armia dotychczas nie została zdemobilizowana. Przeprowadza się reorganizację i naznacza nowych dowódców. Tego być nie powinno. Ja przeciwko temu protestuję. Otrzymuję wiele skarg o niezapłaconych należnościach ludziom zasłużonym, zdemobilizowanym polakom i białorusinom z Kresów. Rzecz oburzająca. Ludzie, którzy stracili swe zdrowie w obronie Polski spotykają się wciąż z odmową

\footnotetext{
${ }^{e-e}$ Nieodbite, dopisane ręka Stanisława Bułak-Bałachowicza; ${ }^{f}$ Powtórzenie.
} 
pieniężną na kurację - rodziny internowanych ${ }^{g}$ pozostające w nędzy nie otrzymują żadnych zasiłków, gdy tymczasem ${ }^{g}$ dla

\section{k. 8 listu (k. $52 \mathrm{w}$ teczce)}

różnych zbójów i awanturników politycznych subsydia są.

Panie Borysie Wiktorowiczu! To pachnie już skandalem, gdyż cierpliwość ludzka ma swe granice. Skarb Polski asygnuje fundusze, a pieniądze te idą $w$ innym kierunku i na odmienne cele.

Zwróciłem się do Rządu Polskiego z prośbą o przeprowadzenie ostatecznej likwidacji mej armii. Udało mi się nawet część tych ludzi, których Pan wysyłał na rozboje, zatrudnić pracą uczciwą.

Wspomnę w tem miejscu również, że nawet dług, który Pan zaciągnął na rachunek tej problematycznej 3-ej Rosji, ja z upoważnienia moich ochotników w przypadającej części przyjmę na siebie i nie pozostanę dłużnym, gdyż jestem właśnie w trakcie likwidacji mych rachunków z Rządem Polskim. Nie ma jednak zdaje mi się prawa, któreby zabraniało ludziom, krew przelewającym za „naszą wolność i waszą" zająć się pracą spokojną i pożyteczną. Zdaje mi się również, iż dla Pana „widzimisię” i eksperymentów wojackich Rząd Polski sam nie zechce trzymać ludzi za drutami, gdzie systematycznie i celowo urabia się ich na wrogów tej sprawy, której bronili i słuszną prośbę moją rozpatrzy, poprze i uwzględni.

Ażeby więc tę paląca kwestię rozstrzygnąć jak najprędzej proponuję Panu wyjechać łącznie z przedstawicielami wyłonionej ad hoc Komisji Polskiej do obozów jeńców w czasie jak najrychlejszym i zabrać do siebie tych, którzy pragną opieki Pana, ja zaś wezmę tych, którzy nie to, iż mi przyrzekną, że chcą pracować, ale złożą pisemne zobowiązanie, iż w żadnych ruchawkach partyzanckich uczestniczyć nie będą, lecz zajmą się zorganizowaną dla nich przezornie pracą pokojową. Nie będzie wówczas mogło być mowy o jakichś „bałachowcach” urządzających partyzantkę na Białej Rusi.

Jednocześnie zaznaczam, iż wypuszczając z obozów element najbardziej skompromitowany, co do wartości moralnej [co do] którego nie mogły istnieć żadne wątpliwości, utracił Pan eo ipso prawo na dokonywanie selekcji materiału ludzkiego w obozach internowanych. Przedstawia Pan Rządowi Polskiemu dane

\section{k. 9 listu (k. $53 \mathrm{w}$ teczce)}

statystyczne obejmujące suchą cyfrę kilkunastu tysięcy ludzi. Rekomenduje Pan ich in gremio, jako rzekomych Jego zwolenników, a tymczasem faktycznie ma Pan ich niewielu i gdyby tak przyszło Panu z nimi istotnie bronić na polu walki jakiegoś poważniejszego hasła lub idei ......

\footnotetext{
8-8 Ostatni wers nieodbity, dopisany ręka Stanisława Bułak-Bałachowicza.
} 
I piszę ja to Panu otwarcie. Za najniewinniejsze przeciwko Panu wystąpienie naklejał Pan na ludzi rozmaite etykiety, nazywając ich w swoim języku politycznym to monarchistami, to germanofilami, to komunistami, to wreszcie obywatelami ziemskimi. $Z$ różnym powodzeniem próbował Pan czynić to również ze mną.

Panie Borysie Wiktorowiczu - ja zawsze brałem pod uwagę fakta. Porównywałem to, co człowiek mówi ${ }^{h}$, a nawet pisze, $\mathrm{z}$ tym co czyni.

Wielokrotnie zastanawiałem się nad tem, czy Pan jest tylko człowiekiem umysłowo krótkowzrocznym, czy też przestępcą. I wyznać muszę niestety, iż utrwaliłem się w tem drugiem określeniu, to z powodu faktów, które przytoczę:

Kogo Pan na początku popierał i finansował w Polsce?

Glazenappa, hr. Pallena, Elwengrena ${ }^{9}$, pułk[ownika] Palakowa ${ }^{10}$, jen[erała] Boboszko ${ }^{11}$ i innych. Pan czynił to świadomie - czy też nieświadomie? Są dowody, że czynił Pan to świadomie.

Wszak po wyjeździe Pańskim z Paryża ${ }^{12}$ otrzymał Pan od działaczy politycznych odpowiednie co do tych osób przestrogi właśnie wtedy, gdy Pan chełpił się, iż dążyć będzie do zlikwidowania armii Bałachowicza, a dla Rosji będzie Pan w Polsce drugim WALLENRODEM.

Jakąż była orientacja polityczna powyżej wymienionych działaczy, którym Pan użyczała swego szerokiego poparcia. Jakie były ich plany? Wiadomem chyba było Panu, iż oni będą realizować na gruncie polskim swe germano-monarchistyczne koncepcje szczegółowo opracowywane w Berlinie w myśl których powstrzymywać się będą do ostatka od wystąpień zbrojnych w obronie Polski, zerkając stale w stronę Niemiec, przy pomocy których miał dopiero w Rosji powstać ład i porządek. A jednak wspierał ich Pan i finansował kosztem Skarbu Polskiego na rachunek tej [3-]ej Rosji.

Jestem w posiadaniu aktów i dokumentów stwierdzających pracę prowokacyjną tych działaczy na froncie, kiedy to w końcu czerwca r[oku] ub[iegłego] gdym gwałtownie potrzebował rezerw, zgromadzonych właśnie

${ }^{h}$ Coś zamazane i nadpisane maszynowo - „mówi”.

9 Elwengreen [Elvengren/Elwingren/Elwengren] Ernst Emirowicz (1865-1935). Jako pułkownik wybitny dowódca eskadronu i oficer sztabowy. Generał. „Północny przedstawiciel”, reprezentował kronsztadtowców wobec REK. Miał otrzymać od REK 1 mln marek.

${ }^{10}$ Poljakow Boris Piotrowicz (1883-1956) do Armii Północno-Zachodniej przeszedł od czerwonych. Kwatermistrz [naczelnik aprowizacji] Korpusu Północnego w Polsce i w Niemczech. Uczestnik zjazdu monarchistycznego w $1921 \mathrm{r}$.

${ }^{11}$ Boboszko Lew Aleksandrowicz (1883-1966). Po rozformowaniu Armii Północno-Zachodniej znalazł się ma terytorium Polski, gdzie powierzono mu dowództwo dywizji w formowanej 3 Armii. 1 Dywizja pod jego dowództwem walczyła w rejonie Płoskirowa. W wyniku zawarcia polsko-rosyjskich preliminariów pokojowych Boboszko został internowany, a po zawarciu traktatu ryskiego wyjechał z Polski (przez Grecję) do USA. Brał czynny udział w życiu rosyjskiej emigracji.

12 Mowa o wyjeździe do Paryża, planowanym w trakcie posiedzenia REK z 21 marca $1921 \mathrm{r}$. 


\section{k. 10 listu (k. $54 \mathrm{w}$ teczce)}

właśnie ${ }^{i} \mathrm{w}$ Brześciu Litewskim, wskutek agitacji tych działaczy odmówiono mi wysłania posiłków. Cóż Pan uczynił dla ukarania winnych, pomimo mych meldunków? Powie Pan, iż zwrócił Pan uwagę na ten fakt Rządu Polskiego. Ale kiedy? Wtedy - kiedy zaczęli oni przeciwko Panu agitować - ale kiedy pracowali wbrew interesom Polski, to Pan dyskretnie milczał i popierał ich.

Przy zawieraniu umowy ze mną oświadczył Pan że dba o mój honor i mojej armji. Przekazałem Panu sądownictwo, kierunek polityczny i kontrolę nad armią. I cóż się okazało? W papierach kancelaryjnych tkwi wiele nazwisk osób oskarżonych i skompromitowanych. Dziwna rzecz jednak, iż żadnego z winowajców nie ukarano, przeciwnie wszyscy faktyczni przestępcy zdołali ujść w porę. Ja jednak - jak to Panu wiadomo - z przestępcami rozprawiałem się nie na papierze, intrygi w tym zakresie były mi obce. Są na to dowody.

Niewybredny jest Pan również w systemie kaptowania sobie ludzi. Ot daje się tak z lekkiej ręki milion marek polskich lub pół miliona, co też jest stwierdzonem (pułk. Mikosza, pułk. Duchopilnikow), asygnuje się sumy na prawo i na lewo z wyliczania się z ich użytku nie jest znowu tak bardzo obowiązującym, o ile oczywiście dany osobnik sprzyja Panu. W przeciwnym razie zjawia się oskarżenie z odpowiednim komentarzem. W ogóle trzyma się Pan tej taktyki, im więcej ludzie są skompromitowani, tem więcej są pożądani, bo można ich zawsze mieć w rękach.

Oświadczyłem już Panu zarówno jak i Rządowi Polskiemu, że posiadam wszystkie niezbędne dowody i dokumenty. Oskarżał Pan niektórych moich ludzi o defraudację itp. Po oskarżeniach dawał im Pan pieniądze. Panie Borysie Wiktorowiczu, ja za defraudacje mniejszych sum rozstrzeliwałem - example Dr. Jankowski. Sąd N[arodowej] A[rmii] O[chotniczej] jest bardziej srogi. Oprócz sądów i kontroli zewnątrz wypływających z powodu operacji na terenach różnych państw, obowiązywały w równej mierze sądy wewnętrzne mojej organizacji, od wyroków których jeszcze nikt nigdzie ukryć się nie zdołał i nie zdoła. W rocie przysięgi N[arodowej] A[rmii] O[chotniczej] jest powiedziane „nie masz sądu bardziej nieubłaganego”. Sądowi temu

\section{k. 11 listu (k. 55 w teczce)}

Panie Borysie Wiktorowiczu, podlegamy wszyscy nie wyłączając i Pana. A im większe stanowisko - tem większa odpowiedzialność. Na jednem z zebrań R[osyjskiego] $\mathrm{K}$ [omitetu] P[olitycznego] oświadczył Pan np., że sprawę mego b[yłego] intendenta Jelina trzeba zatuszować, aby nie kompromitować mnie oraz, że jeżeli Jelin będzie sądzony, to wszystkie moje sprawy będą wycofane. Oświadczenie to jest zaprotokołowane przez moich sędziów. Zgodzi si Pan, iż oświadczenie tego rodzaju było rzuceniem cienia

\footnotetext{
i Powtórzenie w oryginale.
} 
podejrzenia w moją stronę. Niech Pan wie, że nieporządki i niedokładności wszędzie się zdarzają. Ja pracowałem $\mathrm{z}$ moją kadrą $\mathrm{w}$ najcięższych warunkach i wszelkie ze strony Pana oskarżenia mojej armii, która osiągnęła kolosalne zyski materialne były tendencyjnymi, czynił Pan to z rozmysłem dla odwrócenia uwagi i co dziś już zostało przez kontrolę stwierdzone dla ukrycia własnych kolosalnych niedoborów.

Działalność mojej kadry była stale bagatelizowana bo wszak ona „nie za sprawę rosyjską walczyła". Ceniąc niby to N[arodową] A[rmię] O[chotniczą] był Pan od początku do końca zawziętym jej prowokatorem i prokuratoremj. Stosownie zaś do danych, będących w posiadaniu naszej organizacji, wciągnął Pan wiele osób w rozmaite zawiłe kabalistyki finansowe i tu należy szukać genezy popularnego dziś powiedzenia, albo złodziej, albo sługa Sawinkowa - tertium non datur. Różnica polega tylko w nazwach. Tak oto zostali ludzie przez kuglarstwo Pana mem zdaniem tylko obałamuceni.

Panie Borysie Wiktorowiczu, dzieją się na świecie różne rzeczy. Piszemy sami o sobie historię, ale i o nas nieznani historycy piszą opierając się na ${ }^{k}$ najbardziej realnych podstawach. Myli się Pan bardzo mniemając, iż będąc w posiadaniu funduszów otrzymanych na rachunek tej 3-ej Rosji wszystkie swe braki i niedobory w budżecie i rachunkach łatwo Pan zwali na ludzi, których się Panu oskarżyć podoba.

Oświadczyłem Panu, iż byłoby zupełnie ${ }^{l}$ wytłumaczonym, by niektóre akty i dokumenty mogły zaginąć - ja jednak dokładałem wszelkich starań, aby niezbędne dokumenty dla Kontroli zachować, gdyż zarówno ze względu na przyszłość, jak i dla korzyści sprawy pożądany jest sąd bezstronny i sprawiedliwy.

\section{k. 12 listu (k. $56 \mathrm{w}$ teczce)}

Działalność nasza musi podlegać kontroli ogólnej ze względu na nasze stanowisko. Za błędy popełnione musimy ponieść odpowiedzialność.

Wspomnę, że ja specjalnymi rozkazami do armii mojej zalecałem powściągliwość w wydawaniu awansów do chwili uregulowania rachunków poprzednich. Pan postępował inaczej. Milionami wydawał Pan ludziom pieniądze, na rachunek mojej armii, bez mej wiedzy i upoważnienia. Żąda Pan przykładu.... Wojciechowski czy się wyliczył z otrzymanych awansów? Nie ... roztrwonił nawet sumy powierzone mu na wypłatę żołnierzom. A jakaż za to spotkała go kara - nowy awans, opieka Pana, ułatwienie przejazdu na aranżowanie pogromów i bandyta ten po powrocie z Kresów dziś spokojnie grasuje po Warszawie, a wszak wiadomem jest chyba Panu że człowiek ten był przezemnie zdegradowany i stał pod kulą karabinu. Niech więc Pana nie dziwi, że ja w swoim czasie na jego propozycję rozstrzelania kilku ludzi wskazanych jako winnych tego nie uczyniłem, pomimo iż nawet istniały co do nich podejrzenia i poszlaki, gdyż musiałbym przedewszystkim zacząć od Pana.

\footnotetext{
${ }^{j}$ Wstawione odręcznie przez Stanisława Bułak-Bałachowicza; ${ }^{k}$ Dostawione maszynowo nad wersem; ${ }^{l}$ Coś (maksymalnie 3 litery) zamazane piórem.
} 
Tak Panie Borysie Wiktorowiczu, list ten nie dla komentarzy w redakcjach jest zredagowany - niema on też na celu wywołania sensacji - oświetla on jedynie działalność Pana jako polityka strategika, opiekuna mojej b[yłej] armji i szkodnika politycznego.

Nie roztrząsałem pracy i nie analizowałem czynów Pana, aby tym sposobem wybielić siebie, gdyż w danym stadjum sprawy trybunał sądowy może być jedynie tą instancją, która o pracy naszej wyda odpowiednie orzeczenie.

Rząd Polski patrzył dotychczas na moją sprawę z Panem jako na zatarg nasz wewnętrzny. Jeżeli jednak doszło już do tego, że posłowie ${ }^{13} \mathrm{z}$ trybuny sejmowej powtarzają rozkolportowane fałsze, zwracają się pod adresem moim z zarzutami mężowie stanu, przedstawiciele misji obcych zapytują mię o rezultatach sprawy finansowej mej armii i o wynikach badań inkryminowanych pogromów, zatarg przeistacza się w sprawę zewnętrzną, wzbudzającą zainteresowanie zarówno w kraju, jak i za granicą. Niektóre strony tego zatargu godzą bezpośrednio w Rząd Polski, więc już choćby z tego względu sprawa nasza musi być zademonstrowana w sądzie - publicznie.

\section{k. 13 listu (k. 57 w teczce)}

To po pierwsze, - po drugie zaś, aby mnie nie posądzano o jakoweś konszachty finansowe $z$ Panem a 'conto tej 3-ej Rosji - ja w imieniu moich ochotników oświadczam: „służyłem przede wszystkiem Ojczyźnie mej Polsce i pokrewnemu mi ludowi białoruskiemu, Sawinkowowi nie służyłem nigdy".

W ostatnim skierowanym do mnie liście proponował mi Pan łamy swego pisma dla prowadzenia polemiki. Uważałem za niestosowne skorzystać z Pańskiej propozycji ${ }^{m}$. W tem jednak miejscu muszę Panu zaznaczyć, że o ile Pan pozwoli sobie w dalszym ciągu pisać nonsensa i miast do nawoływania do pracy organizacyjnej będzie Pan podawał wiadomości o jakowych formowniach wojsk, przyczynach ich dyslokacji, gdzie jest stale wspominane moje nazwisko, jak również zamieszczać artykuły w rodzaju: „Co robić”, następnie inspirować notatki burzące umysły białorusinów o jakowyś „okupantach” lub swawoli panów komisarzy, których nikt po tamtej stronie polskiej granicy wschodniej panami nie nazywa, a co jest skierowane pod adresem administracji polskiej - zamieszczać wreszcie protesty od imienia Związku Obrony Ojczyzny i Wolności, w których żonglerka polityczna idzie w parze z prowokacją - to będę zmuszony odpowiednio na to zareagować. Czy Panu żaden z konfidentów Pana jeszcze dotychczas nie wyjawił, że pismo przez Niego redagowane jest najlepszym

" Sowo "propozycji” nadpisane maszynowo.

13 Komplet uwiarygodnionych odpisów wymienionych listów i biletów Stanisława Bułak-Bałachowicza z posłem Adolfem Świdą (z Klubu Zjednoczenia Mieszczan) złożony przez Stanisława Bułak-Bałachowicza w dniu 10 lipca 1921 r. na ręce „Wnego Pana Dubiejkowskiego, Pr. Kom Białoruskiego” znajduje się w LCVA, Fond 281, opis 1, teczka 12, k. 16-31. 
środkiem agitacyjnym po tamtej stronie frontu - ad usum komunistów, gdyż stale komentuje fałsze.

W organie swoim w art[ykule] p.t. „Co robić zaliczył pan mnie do rzędu winowajców nieszczęść narodowych w Rosji na równi z Judeniczem, Kołczakiem, Wranglem i innymi. A jakąż wobec tego dać nazwę robocie Pana?

Czy Panu np. nikt dotąd nie zwrócił uwagi, iż ten utworzony przez Pana Związek Obrony Ojczyzny i Wolności cieszy się wśród włościan rosyjskich opinią Związku Zaprzepaszczenia Ojczyzny i Wolności, gdyż oddziały tego Związku były tak nieudolnie zorganizowane, iż wpadły wszystkie w ręce czerezwyczajek. Przelała się przy tem krew nieświadomych, reszta zaś włościan faktem tym zaskoczona przypomina „szewszczyznę” i spoziera w kierunku osoby twórcy i organizatora tego Związku.

\section{k. 14 listu (k. 58 w teczce)}

Twierdzi Pan, iż dla zwycięstwa potrzebne są ofiary. Jest to słuszne. I tem chyba wytłomaczyć należy iż z jednej strony kilkuset ludzi wydał Pan na pastwę czerezwyczajek, a z drugiej zaś zwerbował Pan podejrzane indywidua i pchnął je pan na aranżowanie ruchawek zbrojnych $\mathrm{z}$ akompaniamentem pogromów i rabunków, dokonywanych w dodatku pod moją firmą. Nie dość na tem. Represjami stosowanemi względem internowanych i karygodnym uporem $\mathrm{w}$ stosunku do niewy[pu]szczania ich zza drutów na roboty, gdzie zdolniejsi i dzielniejsi z nich mogliby znaleźć pracę i utrwalić jako tako swój byt materialny, wytwarza Pan w ich szeregach nastrój wrogi względem Rządu Polskiego.

Akcja ta dłonią Pana kierowana w wyniku praktycznym jest pożyteczna jedynie dla bolszewików, niemców i rosyjskich reakcjonistów-monarchistów.

Może Panu ciężko zorjentować się w wynikach Jego pracy? Postaram się pomóc Panu w tym wypadku. Rezultaty te są następujące: krwawa likwidacja zorganizowanego przez Pana Związku Obrony Ojczyzny i Wolności na terytorium Białej Rusi i Rosji przez komunistów, co posłużyło pretekstem do represji ludności miejscowej i posiało wśród niej zwątpienie. Panu zaś nie dało być może zadowolenia, ale dało reklamę okupioną krwią włościan i ludzi ideowych. Wrogom dał zaś jeszcze jeden dowód Pańskiego organizacyjnego talentu. Niemcom daje to ${ }^{n}$ olbrzymi materiał do rozpowszechniania po całej Europie, że pogromy organizowane na Białej Rusi mają swe źródło wśród organizacji ros[yjskich] działających w Polsce, a że imię moje jest tu też wplatane więc wynika, że $\mathrm{R}$ [osyjski] K[omitet] P[olityczny] pogromy te popiera. I nie tylko rozpowszechniane są wersje lecz i publikowane w pismach $\mathrm{z}$ wymienieniem miejscowości pogromów, nazwisk ofiar i zdjęć fotograficznych. Są one ${ }^{o}$ dostarczane do misji obcych - na co są dowody. Czyż Pan sądzi, że Niemcy nie wyzyskują tego dla obniżenia marki polskiej

${ }^{n}$ Wstawka odręczna piórem; ${ }^{o}$ Wstawka odręczna piórem. 
i agitacji przeciwpolskiej. Ale to jeszcze nie wszystko - jest rzecz ważniejsza. W miarę ukazywania się not Cziczerina i rozgłosu o tej partyzantce stosują się większe represje do ludzi zupełnie niewinnych. Gdzie - w Polsce, przez kogo - przez Rząd Polski (Pan jest na uboczu). Wytwarza się wśród ${ }^{p}$ internowanych atmosfera rozgoryczenia, nieufności, usposobienia ${ }^{q}$ Wrogiego. Knują się jakieś spiski, zawiązuje się łączność ${ }^{q}$

\section{k. 15 listu (k. 59 w teczce)}

przez uciekinierów z obozów z Berlinem i masz Pan gotową gratkę dla Niemców. W razie jakichś wystąpień niech Pan będzie pewnym, że to właśnie Pan ich tak przygotował.Warto się głębiej nad tym zastanowić. Czyżby Pan istotnie był tak umysłowo zaślepiony?

Przytoczę tutaj jedną charakterystyczną rozmowę jaka się odbyła na radzie podczas okolicznościowej herbatki, z treścią której większość się jednak zgadza: wszyscy macie pretensje do Sawinkowa, nie jest on tak niebezpieczny jak się zdaje, a nawet w danej chwili pożyteczny. Kontaktu z nim zrywać nie należy i trzeba go nawet popierać. Niech on sądzi, że nas monarchistów można przerobić. Jego wszelkie zarządzenia odnośnie wojsk i osób cywilnych są nam b[ardzo] na rękę. A mianowicie; im większy ucisk i niesprawiedliwość spotyka oficerów i żołnierzy w Polsce, zwłaszcza tych co oddali Polsce wszelkie usługi, szczególniej ludzi śmiałych i zdecydowanych - tym większy fundament na przyszłość i na korzyść Rosji, oczywiście w razie jakiś powikłań ludzie ci jako wartość bojowa są dla sprawy polskiej straceni. I w każdym razie takiego Sawinkowa będzie można zawsze usunąć. Byłoby o wiele gorzej, gdyby ludzie ci byli odpowiednio wynagradzani i byli na swobodzie. Może Pan przypuszczać, że to fantazja, ale ma ona bardzo realne podstawy i mówi wymownie sama przez siebie.

Czy przyszło kiedy Panu na myśl dlaczego to Bałachowicz tak owocnie walczył $\mathrm{z}$ bolszewikami i cieszy się uznaniem wśród ludu.

1) Przede wszystkim jest z krwi i kości synem ludu - nie służy ludowi lecz sprawie ludu. Podjąwszy walkę $\mathrm{z}{ }^{r}$ uzurpatorami władzyr sam władzy tej nie nadużywa. Czego dowodem że w ciągu 3-ch lat walki domowej z bolszewikami przeprowadzał demobilizację siłą pędzonych do boju żołnierzy krasnoarmiejców, a oswobodzone miejscowości oddawał pod administrację samorządów lokalnych. Podjąwszy walkę za swobodę ludów też nie na papierze jak to czynili Judenicz, Rodzianc [Rodzianko] i Pan - ale czynem bronił niepodległości Estonii pod jej sztandarem i Łotwy. Pierwszy $\mathrm{z}$ wodzów armii północnej sformował mu na terenie rosyjskim pod sztandarem Polskim w Pskowie rozkazem $23 \mathrm{~V}$ oddział polski złożony ${ }^{s} z$ polaków i podniósł go na ziemi ruskiej z hasłem za naszą i waszą s.

${ }^{p}$ Wstawka odręczna piórem; ${ }^{q-q}$ Ostatni wers napisany odręcznie piórem; ${ }^{r-r}$ Dopisek odręczny $w$ pustym miejscu $w$ wersie; ${ }^{s-s}$ Dopisek piórem $w$ ostatnim nieodbitym wersie. 


\section{k. 16 listu (k. $60 \mathrm{w}$ teczce)}

W Polsce zaś wykazawszy dzielność demokratycznych przedstawicieli ludu rosyjskiego, którzy dzielnie walczyli w obronie waszej i naszej wolności - wzniósł sztandar rosyjski, który godnie i entuzjastycznie był przez społeczeństwo i przez wojsko polskie witany. W walce za niepodległość Białej Rusi wzniósł chorągiew Białoruską i stanął $\mathrm{z}$ nią nad Dnieprem.

Zawdzięczając jednak tylko zdradzie formacji rosyjskich z Panem na czele zmuszony był wycofać się, gdyż nie można łgać i nie można ludzi gnać, trzeba ich prowadzić, a gdy nadejdzie chwila ostateczna trzeba z nimi iść naprzód. Od r[oku] 1914 nie mam przegranego ani jednego przedsięwzięcia zbrojnego. Gdyż nawet wycofanie się moje ${ }^{t}$ z Białej Rusi w takich okolicznościach nie uważam dla siebie za porażkę.

Panie Borysie Wiktorowiczu; pan jesteś łgarzem co już stwierdziłem aktem. W Mozyrzu i Turowie gdy zachodziła potrzeba ograniczenia się są Pańskie słowa znamienne: „Gdybym wiedział, że chodzi o Białą Ruś, nigdybym nie poszedł”. Szczere przyznanie ale wielce charakterystyczne.

Jest lepszy jeszcze fakt z ilustracją dla historii: Otóż jeden rosyjski polityk piszący antypogromowe rozkazy nie tylko, że sam brał udział w wypadkach, gdzie demoralizował moje pułki zachęcając je słowem do gwałtu, nie chciał przyjąć skromnej świtki białoruskiej ofiarowywanej mu przez włościan, lecz wdział z żyda zrabowaną szubę, a ponieważ przykład idzie $\mathrm{z}$ góry, więc tego demokratę zaczęto $\mathrm{w}$ pułku naśladować. Tam też nastąpiły kumania sięu jego i czułostki z ludźmi o nizkiej wartości moralnej, których ten demokrata obecnie z powodzeniem używa do swych imprez militarnych i tym demokratą jest niestety Borys Wiktorowicz SAWINKOW ${ }^{v}$ we własnej osobie.

Dużo dałbym, żeby to była nieprawda, ale niestety tak było. Tego się ukryć nie da. Zrozumiałe są więc wszelkie Pańskie wysiłki i tendencje dyskredytowania osób, któreby o tem coś miały do powiedzenia. Zrozumiałe są też ciche sposoby likwidowania mojej armii. Obawia się Pan świadków. Przez swoich agentów musi być Panu wiadomem, iż sprawa ta była szeroko komentowana w obozach internowanych. Miałem u siebie delegację, która chciała z tego zrobić użytek w prasie. Nakazałem jednak tym ludziom milczenie, sprawa brudna i ${ }^{w}$

\section{k. 17 listu (k. $61 \mathrm{w}$ teczce)}

Wszak kadra armii, która wyszła sama, po ucieczce Pana nie dostała żadnych produktów. Gdzie się one podziały? Gdzie była Pańska kontrola? Wszak mego imienia na którego chciał Pan zwalić wszystkie winy wtedy nie było. Wszystko spoczywało w rękach pańskiego brata, który miał prawo dyktatora, a który nie zabezpieczył bytu żołnierzy ani załatwił

${ }^{t}$ Wstawka piórem; " Wstawka piórem; ${ }^{v}$ Wersaliki w oryginale; " Nieodbity wers na k. 16 strony, brak dopisku. 
rachunków z organizacjami białoruskimi jako to rachunków ${ }^{x}$ Białoruskiego Komitet ${ }^{x}$ na sumę 470 000,-mk - stworzonego przez Pana, jak się Pan wyraził z durniów, aby łatwo było się ich pozbyć. Brat Pański wywiózł do Warszawy $7^{1} 2^{1} 2^{y}$ milina rubli carskich i kiedy organa partji chciały te fundusze zatrzymać ja sam zaprotestowałem temu motywując to tym, że pieniądze te zostaną użyte na cele właściwe i że wszak tacy ludzie pomimo popełnionych nietaktów nie zechcą skrzywdzić organizacji, które kredytowały.

A jeszcze do dziś dnia należności [b.?] K[omitetu] B[iałoruskiego] nie zostały wypłacone na co mam akta i dowody. Fakt to też znamienny Panie Borysie Wiktorowiczu.

Tak Panie Borysie Wiktorowiczu dałem panu czas do uprawiania Jego polityki względem moich ludzi podług swego „widzimisię”. Za ten czas ucierpiało wielu niewinnych. Dużo zła wyrządził Pan tym, których trzeba było wynagrodzić, a wynagrodził Pan tych, których trzeba było ukarać. Lecz to też było pożyteczne. Szkody frontowi w obecnej chwili Pan nie wyrządza, ale gdyby Pan usiłował ją wyrządzić na przyszłość to $\mathrm{w}$ tym celu ja zakładam swoje veto względem kontynuacji przez Pana podobnej roboty otwieram nie tylko Panu oczy na rzeczy, których Pan dotąd nie chciał dostrzedz, lecz i oświetlam w oczach osób właściwych działalność Pana z punktu widzenia interesów polsko-rosyjskich, polsko-białoruskich, a nie odwrotnie.

Materiał, który podaję w moim liście sądzę, że będzie wystarczającym zarówno dla Pana jak i dla osób, których uwagę pragnąłbym zwrócić i zainteresować dla korzyści sprawy. A śledztwo, o ile takowe będzie dla sprawy potrzebne, wykaże machinacje ze strony Pana i jego adoratorów, że za nie ongiś moi współrodacy u Pana ziomków mieli gościnę na Kamczatce i Sachalinie.

Gdyby to się tyczyło tylko mojej osoby i dajmy na to moich ludzi, ale działalność Pan zatacza szersze kręgi, obejmuje

\section{k. 18 listu (k. 62 w teczce)}

rozleglejsze widnokręgi, a przez-to wytwarza sytuację w skutkach swych nieobliczalną zarówno dla spokoju R[zeczypospolitej] P[olskiej] jak i dla walki o prawdę.

Odpowiedzialność za to przed ludźmi, przed ogółem społeczeństwa i krajem poniosę również i ja - bo chociaż powiedziane jest, że mowa jest srebrem, a milczenie złotem to $\mathrm{w}$ danym wypadku milczenie z mej strony równałoby się śmierci zadanej prawdzie t.j. ideałowi, za który tyle krwi już przelałem. Tak Borysie Wiktorowiczu i te słowa w liście moim nie są powodowane rozgoryczeniem osobistym, lecz oburzeniem i pragnieniem sprawiedliwego rozważenia tej pod względem przewrotności pokrewnej polityce germano-bolszewickiej, przynoszącej z dnia na dzień coraz większe szkody materialne nieobliczalne w swych następstwach.

${ }^{x-x}$ W maszynopisie jest B. K. Na tym nadpisane „iałoruskiego" Komitetu; ${ }^{y}$ Bardzo niewyraźnie odbite. 
Nie mogłeś Pan wynaleźć przeciwko mnie sposobu, trudno było Panu stworzyć ze mnie jakiegoś „sijatielnawo”"14, gdyż wiadomem jest, że jestem synem ludu - niełatwo było Panu wobec mej działalności przekonać ogół o mych inklinacjach monarchistycznych, niezbyt też się Panu powiodło w podejrzeniu mnie o germanofilstwo, gdyż przeważna ich ilość chroniła się pod opiekuńcze skrzydła Pana i tam owe dzieło prowadziła. Powie Pan, $\dot{z}^{z}$ wszak oni byli w mojej armii. Tak, istotnie byli, ale dość jak spojrzeć pobieżnie na moją działalność.

Ochotniczo wstąpiłem do walki z Niemcami w roku 1914 po wezwaniu W[ielkiego] Ks[ięcia] N[ikołaja] N[ikołajewicza] do Polaków. Że dobrze ich biłem świadczy pokaźnie ilość zdobytych nagród, awansów i odznak. Po rewolucji już 2 kwietnia 1917 r. wystąpiłem z bronią w ręku przeciwko Bierdersowi i v.Haustowowi, przeprowadzającymi w armii idee bolszewickie i bratanie się z Niemcami (historia armii tzw. Północnej). 5 kwietnia 1918 r. po rozbiciu batalionu II p. niemieckiej piechoty, który mnie otoczył na jeziorze Czudskim koło wsi Smiłazy rozstrzelałem wówczas pojmanych wówczas w wojsku niemieckim zdrajców b[yłych] oficerów rosyjskich Kagelganda, v. Zweigen Manteufla. 28 lipca 1918 pojmałem w powiecie Łużskim b[arona] Frideriksa, usiłującego agitować chłopów przeciwko formacjom rosyjskim tworzonym do walki z Niemcami, on zaś głosił ideę germano-rosyj ${ }^{a a}$

\section{k. 19 listu (k. 63 w teczce)}

W tymże roku 29 listopada rozstrzelałem na granicy Estonii w majątku Neugassen Niemca oficera Szeffela za propagandę wśród wojsk, aby szły z armią niemiecką do Niemiec, a nie walczyły w obronie jakieś Estonii i w tym roku rozbiłem i rozbroiłem kilka oddziałów niemieckich. Wtedy to p[anie] Borysie Wiktorowiczu tacy jenerałowie jak Simanskij, którzy dziś u Pana zajmują stanowisko szefa kontroli, uprzednio zabrawszy pieniądze pułku Ostrowskiego wyjechali z armią niemiecką.

A Herszelmanowicz [?]? A Wandam [?]? A Nef a Wentowt [?]? I zaś nad niektórymi chociaż pełnią kontrolę - ciążą nieskontrolowane przewinienia.

W r[oku] 1919 z mego korpusu rozkazem 21 sierpnia wydaliłem Niemców, jak szefa sztabu bar[ona] Welie [?] i innych. Przez intrygę tych germanofilów byłem usunięty od Dowództwa korpusu, a mój szef sztabu pułk[ownik] Stojskin był rozstrzelany. Takiż los miał spotkać mnie i moich współpracowników. W r. 1920 wydaliłem i oddałem pod sąd prowokatora Mingralskiego[?], on że v. Htreng [sic] - 25 lipca rozstrzelałem prowokatora Niemca Katana, zdegradowałem germanofila Rudnickiego vel Lusina - odsunąłem od

${ }^{z}$ Dopisek piórem; aa Brak odbitego ostatniego wersu k. 18.

${ }^{14}$ Sijatielnyj jest równoznaczne z przysługującym tytułem. Prawdopodobnie publicznie zwrócono się do Bułak-Bałachowicza w sposób, który miał sugerować, iż Bułak-Bałachowicz należy do wyższej niż lud warstwy społecznej. 
dowództwa pułku po dokonaniu prowokacyjnego pogromu w Kamieniu Koszyrskim pułk[ownika] Barskiego vel Beszela, który jak się okazało był adiutantem von der Goltza ${ }^{15}$. Po cofnięciu się armii za linię demarkacyjną aresztowałem germanofila pułk[ownika] Wasiljewa - zdemaskowałem prowokacyjną robotę głośno na zebraniu w R[osyjskiego] K[omitetu] P[olitycznego] w Warszawie delegacji, która przybyła rzekomo $\mathrm{z}$ ramienia Pana $\mathrm{i}^{a b}$ namawiała mię do uznania i podpisania odezwy do Wrangla.

Oto wiązanka faktów ilustrująca moją walkę z Niemcami, zarówno na zewnątrz, jak i w łonie mojej armii.

Borysie Wiktorowiczu, gdzież że Pańskie ${ }^{a c}$ strzały skierowane ${ }^{a c}$ przeciwko Niemcom. Powie Pan, że jest papier. Tak, jest niestety. Pisał Pan historie tym, którzy już ulotnili się do Berlina. A kto ucierpiał? Skarb Polski, bo niejeden z milionów asygnowanych Panu przez rząd Polski wepchnięty został ręką Pańską do ich kieszeni i posłużył im do robienia ich polityki w Polsce. I hałas teraz wszczęty przeciwko nim zza kordonu miotane teraz obelgi wyświadczają im nową usługę, bo otwierają im tem szybciej kredyt w skarbie niemieckim, dają im stanowisko, poparcie w prasie ${ }^{a d}$ dostęp do kierunku politycznego nad formacjami tworzonymi ${ }^{a d}$

\section{k. 20 listu (k. $64 \mathrm{w}$ teczce)}

stanowczo nie dla korzyści mojego kraju. I przez kogo oni to otrzymują - również przez pośrednictwo Pana.

Wygląda to znów jako powtórzenie historii Kierenskij i Lenin. Mądrze to wszystko dosyć robione. Może Pan przeczyć, że to nie tak, ale fakta mówią co innego. Jeżeli jest Pan dzieckiem, któremu sprawiało przyjemność rzucanie kamieniami na dach - a jeśli to dziecko trafiło w okno więc zasłużyło na karę, jeżeli uczyniło to świadomie, to jest złe dziecko i nie powinna ominąć go chłosta. Kontynuuje się zło pod tym względem większe, że stosują się nieuzasadnione represje w stosunku do żołnierzy i oficerów. Czynione jest to ${ }^{a e}$ rękoma polaków, rozgorycza się ludzi, a w gazecie ${ }^{a f}$ Pańskiej w artykułach wspomina się o Polakowych, Glazenappach i innych jako ludziach, którzy znaleźli poparcie i zrozumienie wśród polityków berlińskich. Za nimi z obozów

${ }^{a b}$ Wstawione piórem; ac-ac Słowa maszynopisu zamazane, nadpisane odręcznie: „strzały skierowane”; ad-ad Dopisane odręcznie pod wadliwie odbitym wersem maszynopisu; ${ }^{a e}$ Odręczna wstawka; ${ }^{a f}$ Gazeta poprawione $z$ "gaziety".

${ }^{15}$ Gustav Adolf Joachim Rüdiger Graf von der Goltz (1865-1946). Dowódca wojsk niemieckich (6 Korpusu Rezerwowego), działających w rejonie Morza Bałtyckiego po klęsce Niemiec w I WW, m.in. słynnej niemieckiej „Żelaznej Dywizji", oddziału księcia A. P. Lievena, białogwardzistów i łotewskich Niemców Bałtyckiej Landeswehry. Areną walk była przede wszystkim Kurlandia. Goltz liczył na powstanie Królestwa Bałtyckiego. Walczył z bolszewikami, czasowo współpracował z nowym rządem Łotwy a także włączył swoje wojska do (białej) Północno-Zachodniej Armii. Usunięty ze stanowiska przez rząd Niemiec na skutek nacisku Ententy. Wojska mu podległe zostały rozformowane. Przez dziesięć lat (1924-1933) przewodniczył Niemieckiemu Związkowi Obrony Ojczyzny. 
internowanych każdodziennie uciekają ludzie rozgoryczeni, lecz stanowiący cenny materiał z punktu widzenia politycznego i wojennego.

Borysie Wiktorowiczu - świadomie tworzysz kadry armii dla Niemców, które przy lada sposobności pierzchną lub przejdą na stronę bolszewików. I to dobre kadry. A wszelkie nieużytki i darmozjady ze względu na humanitaryzm ${ }^{a g} \mathrm{R}[z e c z y p o s p o l i t e j]$ Polskiej ${ }^{a g}$ trzyma Pan obciążając ubogi Skarb Polski.

Przystąpił Pan do pracy obrabiania mojej armii. Panie Borysie Wiktorowiczu najgorszy element wysłał Pan na uprawianie pogromów pod moją firmą, mając na celu dyskredytowanie mnie przed Europą, głosząc o rzekomych powstaniach, czynionych jakoby na Białej Rusi. Pomimo mych przestróg zdołał Pan jednak uśpiwszy czujmość władz polskich pod różnymi pretekstami wysłać kilkuset ludzi łącznie z oficerami na partyzantkę łudząc i ich zarówno jak i pewne sfery rządowe w Polsce, szerokimi perspektywami politycznymi, a faktycznie wysłał ich Pan na śmierć i zagładę, a tym co zostali, uniemożliwia Pan rozpoczęcie tej pokojowej i uczciwej pracy, jaką dla nich uplanowałem i którą pomimo przeszkód zrealizować pragnę i zrealizuję. Prowadzisz Pan nawet już agitację wśród tych ludzi, którzy zajęci są pracą, aby ich pchnąć na awantury i podobnie jak to było

\section{k. 21 listu (k. $65 \mathrm{w}$ teczce)}

z drużynami roboczymi Białoruskimi, które Pan sprowokował posławszy niektórych łatwowiernych na partyzantkę, przyczyniając się tem samem do internowania pozostałych.

Z pracy Pana wynika, że narobiwszy kaszy, drapniesz Pan za przykładem i szukasz Pan jeno pretekstu. Nie chcę przyczynić się aby ten list właśnie umożliwił Panu ucieczkę - a pragnę aby Pan uczciwie załatwiwszy swe porachunki i zobowiązania względem wierzycieli począł żąć plony swego siewu. Czynię to ze względu na swoich ludzi, co do których jak to już zaznaczyłem mam pewne ${ }^{a h}$ zobowiązania. Zobaczyć się z nimi tak czy inaczej muszę i będę żądać sprawiedliwego z nimi rozrachunku i oceny. O ile Pan będzie mi w tej akcji przeszkadzać i zechce nadal kontynuować swój upór i kierunek swej polityki, zmuszony będę nie przebierając w środkach wyprowadzića ${ }^{a i}$ sprawę na forum publiczne. Wszystkie postrachy i groźby zamachów skierowanych pod moim adresem - uważam za dziecinadę niegodną stanowiska męża dojrzałego. Wiadomy mi fakt nieostrożnej gawędy pańskich adhersatów [tak w oryg.] w dn. 7 b.m. przez telefon i prywatnie o uniemożliwieniu mi wyjazdu do obozów celem wizytowania mych ludzi, oświadczenie Pańskiego adiutanta Radina, że nie pożałujecie funduszów na ten cel i że mnie może spotkać „przygoda” w drodze - uważam za grę bardzo nieudolną pod moim adresem. Mojem zdaniem taki praktyczny terrorysta jak Pan

ag-ag Wstawione piórem; ${ }^{a h}$ Nadpisane maszynowo nad zaiksowanym słowem; ${ }^{a i}$ Pierwotnie „wypowiedzieć”, skreślona część „owiedzieć” dopisana „rowadzić”. 
zawsze znajdzie lepszy sposób załatwienia sprawy chociażby ze mną, a wykazawszy gros swej pracy w kierunku prowokacyjnem i w tym wypadku usiłuje ją Pan według swego systemu kontynuować.

List ten jest za długi - lecz nigdy nie chcę pozostać dłużnym. Na mój krótki list z dn. 10 VI za Nr 194 w którym zwróciłem uwagę Pana na uświadomienie Rządu Polskiego o fałszach rzucanych w prasie o mnie i mojej armii i prosiłem o zaniechanie uprawiania dalej podobnej polityki wprowadzającej rozgoryczenie otrzymałem obszerną odpowiedź napisana w imieniu Pana przez p[ana] Iwanowskiego, gdzie oprócz wyłgiwania się, list trąci taką nienawiścią, jakby Panowie prowadzili pracę swą w jakichś obłokach, i przy tem był obłudny. Nie dawał żadnych konkretnych odpowiedzi na moje zarzuty. Żeby więc raz na zaw-

\section{k. 22 listu (k. $66 \mathrm{w}$ teczce)}

zawsze jednym pociągnięciem pióra zakończyć całą tę sprawę którą, jak to przeziera z całej taktyki, wygodnie jest Panu kontynuować i przewlekać do nieskończoności.

Formacje dalej w mojej armii są przeprowadzane. Na czele moich pułków postawieni są ludzie z ramienia Pana jako nowi dowódcy z niewyraźną przeszłością, a ich obecna robota zohydzajaca moją działalność wymaga kontroli, która będzie przeprowadzona, ponieważ fakta są $a^{a j}$, więc aby nie być gołosłownym podaje Panu nazwiska tych ludzi: dow[ódca] pułku konnego płk. Lindezer [Lindener?], Podp. Sosna-Sośnienko i kapitan Kilin [Kilis?].

Podp[ułkownik] Sosna-Sośnienko i pułk[ownik] Lindener na zebraniach oficerskich i wobec żołnierzy odpowiednio bez żadnej ceremonii urabiają ${ }^{a k}$ opinię dla mnie nieprzychylną. Mówią np.: Bałachowicz wobec tego, że jest popierany przez polaków nie może być na tem terytorium sądzony za przelewanie krwi rosyjskiej, ale trzeba wiedzieć, że to jest pogromszczyk i bandyta. Sosna-Sośnienko przytaczał nawet fakt niebywały w historii a przypinany mnie, który oburzył tych, którzy ze mną całą kampanię przeprowadzili, że tymi słowami: że ja jako dowódca armii chcąc się wyzbyć niektórych oficerów rosyjskich wysyłałem ich na pogromy dawając rozkazy, później przyjeżdżałem dla zaprowadzenia porządku i rozstrzeliwałem tych oficerów. Zawdzięczając jedynie R[osyjskiemu] K[omitetowi] P[olitycznemu] zbrodnie te ustały. Rzecz niepotrzebująca komentarzy. Tu należy szukać pochodzenia różnych Lindenerów i Lichaczowych ${ }^{a l} 16$ i innych ich wystąpień przeciwko mnie. Od wystę-

${ }^{a j}$ Słowo nieczytelne; ${ }^{a k}$ Dopisane odręcznie; "al "Lichaczowych" dopisane ręcznie.

16 Według W. Wołkowa pułkownik Lindener był emigrantem w Polsce, internowanym do 10 września 1923 r. w Strzałkowie. Wołkow ustalił dziesięciu Lichaczowych - generała i sztab-oficerów Armii Rosyjskiej, ale biogram żadnego z nich nie wskazuje jednoznacznie na pobyt w Polsce. Być może chodzi o Lichaczewa Jakowa Markowicza, pułkownika artylerii, który zmarł w 1965 r. w Paryżu. Lichaczow, o którym pisze Bułak-Bałachowicz, był autorem oszczerczego względem Bałachowicza artykułu w krakowskim „Naprzodzie” z 25 lutego 1921 r., o którym pisze J. Pelica. 
pujących na podstawie fałszywych dowodów żądałem satysfakcji w tym wypadku żądam kategorycznie śledztwa i sądu, o czem Pana zawiadamiam. Albo ci panowie dowiodą mi miejsca, gdzie to się odbywało, określą czas, wskażą świadków i ofiary, albo też jako prowokatorzy będą odpowiednio ukarani.

Za cały czas mojej działalności w Polsce do czasu przejęcia przez R[osyjski] $\mathrm{K}$ [omitet] $\mathrm{P}$ [olityczny] sądownictwa w mej armii, rozstrzelałem na podstawie wyroku sądu polowego Dr Jankowskiego za defraudację, kpt. Saliwanowa, b. dowódcę czerwonej brygady na froncie za szerzenie fałszywych wieści, ukrycie swej przeszłości i prowokację w obliczu nieprzyjaciela. Rozstrzelałem około Kobrynia plut[onowego] Sawickiego (komunistę) z 2-ma żołnierzami pojmanymi na

\section{k. 23 listu (k. 67 w teczce)}

pogromie żydów. Osobiście rozstrzelałem przed frontem złapanego na rabunku w Sko-

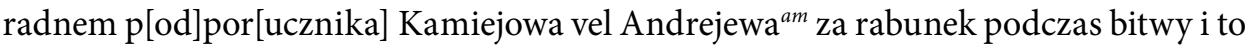
dlatego, że już nikt z oficerów nie chciał za nim ręczyć. W początkach sierpnia r[oku] ub[iegłego]około gorzelni w Łącznej ${ }^{a n}$ ppor. Smirnowa za złamanie znaków w gorzelni, rozpijanie żołnierzy i za agitację pogromową. Wszystko to jest twierdzone aktami i w każdej chwili może być sprawdzone i ujawnione. Widocznie z punktu widzenia rosjan orjentujących się podług wskazówek R[osyjskiego] K[omitetu] P[olitycznego] byli to męczennicy za „istinno russkoje dieło” które jak widać R[osyjski] K[omitet] P[olityczny] popiera i kontynuuje. Mało tych faktów. Nie dość, iż w swoim czasie po zorganizowaniu drużyn roboczych i oddziałów białoruskich Pan przez prowokację subsydiując pieniężnie Dziergacza ${ }^{17}$, Ponia ${ }^{a 0}$ towskiego, dr [Arseniusza] Pawlukiewicza, Maceliego ${ }^{18}$, Orłowa pchnął ich do wystąpień zbrojnych skutkiem czego było internowanie tych drużyn. Dziś ludzie z polecenia R[osyjskiego] K[omitetu] P[olitycznego] prowadzą agitację celem odsuwania do ${ }^{a p}$ pracy pokojowej zajętych już moich ludzi, a mianowicie rotm[istrz] Murawjew, który w r[oku] ub[iegłym] był aresztowany za agitację wśród żołnierzy na korzyść Glazenappa w Brześciu Lit[ewskim] o niewystępowaniu na front, obecnie ofiarowawszy swe usługi w oddziałach werbuje z pośród tych oddziałów ludzi, zachęcając ich do przejścia granicy i ruchów zbrojnych pod kierunkiem pułk[ownika] Pawłowskiego, mających na celu jedynie rabunek. Tenże Murawjew po wypłynięciu jego spraw ukrył się w Warszawie i pracuje w kontakcie

${ }^{a m}$ Wydrukowane nazwisko nieczytelne, zapisane piórem; an Poprawione jak wyżej; ao "Ponia" napisane odręcznie; ap Powinno być „od”.

17 Zob. Łatyszonek (1995).

18 Chodzi o prawosławnego Jana Macelliego, syna Andrzeja i Eudocji Akuło, urodzonego w Mińsku 25 czerwca 1891 r., absolwenta Seminarium Nauczycielskiego, Moskiewskiej Szkoły Podchorążych i kursów leśnych w Moskwie. Macelli do 1 listopada 1918 r. żył u rodziców w Słucku, a od 7 listopada przebywał zmobilizowany na Ukrainie i trafił do niewoli niemieckiej. 
z pułk[ownikiem] Pawłowskim i Wojciechowskim obiecując wyprowadzić 50 ludzi z grona zajętych pracą.

Dzieją się rzeczy jeszcze gorsze. Wobec tendencyjnych pogromów urządzonych przez Pawłowskiego, Wojciechowskiego, Pawłowa i innych było zatrzymane wysłanie na robotę moich ludzi z Pikulic, do czego się przyczyniło inspirowane przez R[osyjski] K[omitet] P[olityczny] doniesienie zredagowane przez k[a]p[i]t[ana] Andrejewa, że ja Bałachowicz mam zamiar rozbroić straż pograniczną polską i z ludźmi wypuszczonymi na robotę udać się na pomoc powstańcom Białoruskim. Z jednej strony k[a]p[i] t[an] Andrejew komunikuje tego rodzaju raport treść którego agenci R[osyjskiego] $\mathrm{K}$ [omitetu] P[olitycznego] kolportują z wyolbrzymieniem po kraju a R[osyjski] K[omitet] $\mathrm{P}$ [olityczny] dokumenty te przesyła władzom polskim. Mało tego, na miejsce zatrzymanych

\section{k. 24 listu (k. $68 \mathrm{w}$ teczce)}

moich ludzi wysyłają się na lepsze i wybrane przeze mnie punkty robót internowani b[yłej] armii z Torunia, z którymi przybyła organizacja z R[osyjskiego] K[omitetu] P[olitycznego] a dla skompromitowania Kooperatywy Zw[iązku] Biał[oruskiego], która miała na celu wyłącznie racjonalne podjęcie robót i nie mieszanie się do spraw politycznych R[osyjski] K[omitet] P[olityczny] wysłał swoją organizację, tzw. "piatierki", dla agitacji celem porzucania robót i przejścia granicy, dla poparcia band grasujących na B[iałej] Rusi. Jakiego to autoramentu są ci agitatorzy „piatierek” i tej organizacji R[osyjskiego] K[omitetu] P[olitycznego], których Pan dobiera, zaświadczyć może fakt przybycia p[ana] Prochorowa, który za prowokację i szantaż dokonany w mojem mieszkaniu w styczniu r[oku] b[ieżącego] odsiadywał karę w cytadeli, skąd po wyjściu subsydiowany przez Pana powrócił do R[osyjskiego] $\mathrm{K}$ [omitetu] P[olitycznego] i został znowu użyty dla tychże celów. Ten osobnik jest Panu dobrze znany.

Cała ta robota prowokacyjna Pana ma na celu zdyskredytowanie mnie za wszelką cenę i wszelkimi sposobami dla większego jeszcze zaniepokojenia władz polskich i zlikwidowania mi drogą projektowanego przez Pana - internowania, którą to myśl już niektórym działaczom polskim zdołał Pan nasunąć i nad czem już odbywały się debaty.

Równolegle z tym na zebraniach urządzanych z przedstawicielami grup partyzanckich Pan kompromituje i władze polskie, gdyż na nie przybywają ludzie w mundurach polskich jak np. pułk[ownik] Sołohub, który skapowany przez Pana, nie licząc się z powagą chwili, nadużywając swego munduru, pozos[t]aje na służbie u Pana i wprowadza w błąd, już nie bacząc na treść jego oświadczeń, ale ze względu na samą jego obecność [wśród] partyzantów, utrwalając ich w mniemaniu, że Rząd Polski popiera ich ruchy i ma zamiar nadal udzielać im swego poparcia. Wprost oburza 
mię, starego partyzanta, ta chęć rozpartyzantowania się wszystkich wtedy, gdy jest to rzeczą zgoła wręcz szkodliwą. Gdzież wy wszyscy byliście przedtem. Wszak mieliście $\mathrm{w}$ swoim czasie szerokie pole do wykonania swych zapałów wojennych.

Jakże możecie zabierać się do odbudowy tej 3-ej Rosji, kiedy wszyscy posiadacie tylko zdolności destrukcyjne. Byłoby to $\mathrm{z}$ wielkim dla sprawy pożytkiem, abyście zechcieli

\section{k. 25 listu (k. 69 w teczce)}

ocenić wasze zdolności i zużyć je w Rosji sowieckiej panie Borysie Wiktorowiczu. Uważam, że wytężenie energii na walkę ze mną wytwarza ferment, daje możność wyzyskiwać poszczególne momenty i sprawie korzyści nie przynosi. Ja który zwykłem nieprzyjacielowi zawsze w chwili kulminacyjnej wymierzać cios decydujący, nie działając nigdy z ukrycia, proponuję Panu rozstrzygnięcie mojej sprawy w taki sposób:

Za cały czas swej działalności usiłował Pan przekonać nas wszystkich, że nie tylko Pan pisze, ale i działa, że posiada Pan wielu zwolenników wśród włościan, że ma Pan głęboko w Rosji ileś organizacji, że posiada Pan rozległe w Europie stosunki wśród demokracji itp. ma Pan za sobą wszystkie organizacje partyzanckie - walczy Pan z pogromami, rabunkami i nadużyciami - pracuje Pan zarówno przeciwko bolszewikom, jak i Niemcom i wogóle jest Pan człowiekiem idealnym.

Obawiając się słusznego zdezawuowania uprzedza Pan fakty, prosi Pan redakcję o wysłanie dziennikarza dla interview z Panem[?] $]^{a q} /$ Hajnt/ i do takiego stopnia posuwa Pan swą sympatię do żydów, że powołuje się Pan na spłodzonego przez Pana ${ }^{a r}$ z żydówką syna, jaki za świadka Pańskiego lojalnego względem żydów usposobienia /Hajnt Nr 181, 9 sierpnia 1921/. Jeżeli Pańskie sympatie pójdą dalej, to można mniemać, że Pan wkrótce przejdzie na judaizm, ale to istoty rzeczy nie zmieni i faktów nie zatuszuje. Tu chodzi o prowokatorów. Wszak dr Brosberg [?] też był żydem i dziś za prowokację aresztowany siedzi w cytadeli.

Wiem, że chodzi tu głównie o ten szyld uczciwego człowieka, którego Pan gwałtem chce sobie spreparować obciążając wszystkich, byleby wyjść z wody suchą nogą.

Nieuczciwie też dążenie Pana wygląda również i pod kątem widzenia interesów Rzeczypospolitej Polskiej, kiedy to Pan niby „pod sekretem” oświadcza dziennikarzom, że jakoby Bałachowicz też otrzymał pozwolenie na formowanie oddziałów partyzanckich na B[iałej] Rusi. O ileby nawet Pan osobiście otrzymał takowe zezwolenie, ono jest jeszcze pod wielkim znakiem zapytania, to tak czy inaczej jest Pan tylko prowokatorem, który tego rodzaju publicznem oświadczeniem szkodę już przyniósł. Trzeba być zbyt gruboskórnym, aby tego nie rozumieć, lub też być do te-

${ }^{a q}$ Właściwie nieczytelne; ${ }^{a r}$ Odręcznie nadpisane. 


\section{k. 26 listu (k. $70 \mathrm{w}$ teczce)}

tego stopnia przewrotnym, aby rozmyślnie udawać naiwnego.

Wiedząc zaś wybornie o tem, iż dążeniem moim było i jest przeprowadzenie uczciwej likwidacji mojej armii, załatwienie rachunków, wynagrodzenie ludzi uczciwych i ukaranie winnych oraz danie im możności zajęcia się pracą, Pan z premedytacją urabia mnie w oczach Rządu polskiego, społeczeństwa i przedstawicieli pism żargonowych, jako aranżera partyzantki i zbrodniarza i recydywistę. Cała indywidualność Pana z jej perwersją ukazała się tu w całej pełni. Kres temu winien być położony w imię prawdy i sprawiedliwości.

Stracieła [Straciłem] w walce o wolność ludów zdrowie, mienie, rodzinę i tu przybywszy do kraju zamiast podziękowania - dzięki Pańskiej wydatnej pomocy imię moje jest w dalszym ciągu szargane, co dotychczas czynili tylko moi najzaciętsi wrogowie.

W interview z przedstawicielem prasy żargonowej oświadczyłeś Pan, że jestem człowiekiem słabej woli i bez charakteru, że zemną jest niebezpieczną wspólna praca. Jest rosyjskie przysłowie „Wie kot czyje mięso zjadł”. Sumienie Panu dyktuje, iż zasłużył Pan na to, że ten człowiek bez woli i charakteru może znaleźć chwilę skupienia się i pociągnąć za cyngiel w stronę Pana. Ujawnia się tu nowy szczegół psychologiczny, który Pan chce we mnie odkryć, aby potem żądać unieszkodliwienia takiego niebezpiecznego dla społeczeństwa indywiduum. I w tym kierunku urabia Pan już opinię. Na wszelkie sztuczki mych wrogów, do których Pan jako zdeklarowany już się przyznał, miałem nawet extra sposoby. Pozostawała alternatywa „albo ja - albo oni”.

Pojedynek z Panem jako z człowiekiem skompromitowanym zaszczytuby mi nie przyniósł, zanim odbędzie się sąd w Polsce, który nastąpić musi, którego żądam i żądać będę - dla ostatecznego przekonania w Polsce Pana i sfer rządzących, proponuję tego rodzaju pojedynek:

Masz Pan Rosjan w obozach urabianych w ciągu przeszło $1 / 2$ roku według swojej modły. Masz Pan agentów, konspiratorów itp. Proponuję z Komisją wyjazd do obozu internowanych i zdanie się na sąd polubowny z udziałem wszystkich partyzantów,

\section{k. 27 listu (k. $71 \mathrm{w}$ teczce)}

internowanych Rosjan [tak w oryg.], co w ciągu 7-u miesięcy w obronie Polski walczyli, którzy ode mnie nic - [za] okres trudów, krwi przelanej, ran, nędzy, upokorzenia i niewoli - nie otrzymali. Proszę o przedstawienie przed nimi mnie jako winowajcę tych wszystkich nieszczęść, jakie ich spotkały i sądem partyzanckim, którym ja karałem - pragnę być ukarany. Człowiek bez charakteru i woli, a w dodatku zbrodniarz, za jakiego Pan mnie publicznie ogłasza, przedkłada śmierć z ręki tychże zawiedzionych przez niego w ich nadziejach ludzi, niż życie jak obecnie, w wypadku jeżeli ludzie ci potwierdzą inkryminowane mi przez Pana lub za jego pośrednictwem winy. $\mathrm{W}$ odwrotnym zaś wypadku to samo musi być zastosowane względem Pana. 
Gdyż dość już tego wszystkiego. Według mnie jest to jedyne racjonalne i uczciwe wybrnięcie $z$ tego chaosu gmatwaniny intryg i diabelskich machinacji. Pan mnie oskarżałeś - ja Pana oskarżam. Na terytorium Polski podlegałem sądom polskim. Oskarżał mnie Pan o uprawianie pogromów, które Pan popełniał i dziś kontynuuje na B[iałej] Rusi, zwalając je na mnie. Zohydzał Pan tym honor mój, mej armii i mej Ojczyzny.

W imię sprawiedliwości żądam satysfakcji.

Jeśli Pan wpajał przekonanie o swych wpływach, tym bardziej Pan ma szanse do zrealizowania tego

16 VIII $1921 \mathrm{Nr} 385$

Za zgodność $z$ oryginałem Stanisław Bułak-Bałachowicz gen. por. ${ }^{a s}$

\section{Źródła archiwalne}

\section{Archiwum Akt Nowych (Warszawa)}

[AAN TSK, sygn. 68, k. 10-14]. Archiwum Akt Nowych (dalej AAN), Towarzystwo Straży Kresowej (dalej TSK), sygn. 68, k. 10-14, „Informacje polityczne” z 26 IV 1920 r.

\section{Centralne Archiwum Wojskowe (Warszawa-Rembertów) ${ }^{19}$}

[CAW, sygn. I.480.72, k. 4]. Centralne Archiwum Wojskowe. Kolekcja Generałów i Osobistości sygn. I.480.72, k. 4 . Wycinek prasowy.

[CAW, sygn. I.480.72, s. 7-8]. Centralne Archiwum Wojkkowe. Kolekcja Generałów i Osobistości sygn. I.480.72, s.7-8. Korespondencja Bułak-Bałachowicza z Komendą Miasta Warszawa ws nieuregulowania należności za przejazd taksówką. Podpis B-B oryginalny.

[CAW, sygn. I.480.72, k. 13-25]. Kolekcja Generałów i Osobistości sygn. I.480.72, k. 13-25. Obszerny, rękopiśmienny list Stanisława Bułak-Bałachowicza z 13 II 1925 roku z podpisem oryginalnym „Do Pana Pułkownika Dyplomowanego Sokołowskiego, Szefa Gabinetu Ministra Spraw Wojskowych przekazany osobiście przez siostrzana Bułak-Bałachowicza W. Czerwińskiego, kierownika Biura Zarządu Interesów D-cy B. Armji Ochotniczej Sprzymierzonej”.

[CAW, sygn. I.480.72, k. 26-36]. Kolekcja Generałów i Osobistości sygn. I.480.72, k. 26-36 Wyjaśnienia St. Bułak-Bałachowicza na stawiane mu zarzuty. Oryginalny podpis B-B.

[CAW, sygn. I.480.72, k. 49-51]. Kolekcja Generałów i Osobistości sygn. I.480.72, k. 49-51. List St. Bułak-Bałachowicza z 20 I 1933 na ręce Pana Posła Walewskiego, Sekretarza

as Podpis oryginalny.

19 Autorka dziękuje mgr. Hubertowi Kuberskiemu za wsparcie w trakcie kwerendy w CAW. 
Generalnego Federacji Związku Polskich Obrońców Ojczyzny. „Gęsty” maszynopis. Papier z nadrukiem St. B-B. Odpis. Oryginalny podpis. B-B.

[CAW, sygn. I.480.72, k. 66-66v-67-67v-68]. Kolekcja Generałów i Osobistości. sygn. I.480.72, k. 66-66v-67-67v-68. List Stanisława Bułak - Bałachowicza z 19 XII 1934 ze Świdra „Do Wielmożnego Pana Generała Dr Romana Góreckiego” Odpis. Rkps. Za zgodność Stanisław Bułak-Bałachowicz.

[CAW, sygn. I.480.72, k. 170-171]. Kolekcja Generałów i Osobistości sygn. I.480.72, k. 170-171. List Stanisława Bułak-Bałachowicza z 27 III 1929 roku do Pana Generała Dyr. Góreckiego Romana Prezesa Federacji Pol. Zw. Obr. Ojczyzny).

[CAW, sygn. 1673/84/3, t. 15, k. 3]. Opinia służbowa o majorze Romanie Umiastowskim.

\section{Lietuvos mokslų akademijos T. Vrublevskių biblioteka (Wilno)}

[LMAB], Fond 21 [tzw. Fond Muzeum Białoruskiego], teczka 857, k. 1. Druk ulotny z epoki.

[LMAB, Fond 255-549, kk. 28]. Memorandum o wydarzeniach kwietniowych 1919 (o pogromie żydowskim) w mieście Wilnie złożony Generalnemu Komisarzowi Ziem Wschodnich p. Osmołowskiemu.

[LMAB, Fond 21-671, k. 33-34]. Graf Tyszkiewicz. Tekst „Celna granica”, rkps.

\section{Lietuvos centrinis valstbes archivas (Wilno)}

[LCVA, Fond 281, opis 1, teczka 12, k. 1-11]. List Otwarty Generała Bułak-Bałachowicza Do Sejmu Ustawodawczego Rzeczypospolitej Polskiej. Odpis z adnotacjami odręcznymi.

[LCVA, Fond 281, opis 1, teczka 12, k. 16-31]. Komplet uwiarygodnionych odpisów wymienionych listów i biletów Stanisława Bułak-Bałachowicza z posłem Adolfem Świdą (z Klubu Zjednoczenia Mieszczan) złożony przez Stanisława Bułak-Bałachowicza w dniu 10 lipca 1921 r. na ręce „Wnego Pana Dubiejkowskiego, Pr. Kom Białoruskiego”.

[LCVA, Fond 281, opis 1, teczka 12, k. 33-34v]. Stanisław Bułak-Bałachowicz Do Pana Ministra Spraw Zagranicznych Nr 507 z d. 8 VII 1921. Uwiarygodniony przez St. Bułak-Bałachowicza odpis.

[LCVA, Fond 281, opis 1, teczka 12, k. 35-40]. [List] Do J. W. Pana Sikorskiego jenerała porucznika szefa Sztabu Generalnego Warszawa 3 Maj 1921. Uwiarygodniony przez St. Bułak-Bałachowicza odpis.

[LCVA, Fond 281, opis 1, teczka 12, k. 45-71]. List Otwarty Stanisława Bułak-Bałachowicza Do b. Prezesa Rosyjskiego Komitetu Politycznego w Warszawie Borysa SAW IN KOWA. Uwiarygodniony przez St. Bułak-Bałachowicza odpis [Aneks].

\section{Gasudarstwiennyj Archiw Federacji Rosji (Moskwa)}

[„VI 1920 - IX 1921”]. GARF P-5866, opis 1, j. chr. 170, kart 12 (nieliczbowanych 24). Ijun 1920 - nojabr 1921 Druk [w języku rosyjskim] małego formatu. Na prawach rękopisu.; (II egz. przechowywany w Amsterdamie - IIVSG, Archiwum Sawinkowa, t. 16, Polsza 2). 


\section{Rosyjski Gosudarstwienny Wojennyj Archiv. Fond Trofiejny. (Moskwa)}

[RGWA, 461K, opis 1, dieło 128, k. 62]. Raport majora i kierownika Wydziału II Sztabu Umiastowskiego z 7 marca 1921 roku.

[RGWA, 308K, opis 9, teczka 744, k. 385-386]. Poselstwo polskie w Paryżu Attache wojskowy nr 118713 XII [1921] Ściśle poufne. Do Szefa Wydziału Wywiadowczego O II Szt. Gen. „Konferencja Waszyngtońska i sprawy rosyjskie. Stanowisko żydów”, s. 385-386.

[RGWA, Protokoły REK]. (W przygotowaniu do edycji źródłowej).

\section{Bibliografia}

\section{Źródła drukowane}

Bułak-Bałachowicz, S. (1922). List otwarty gen. Bułak-Bałachowicza do Sejmu Ustawodawczego Rzeczypospolitej Polskiej. Warszawa: [Zakł. Graf. C.A.B.P.].

Eckart, D. (1921). Totengräber Rußlands. Zeichnungen von Otto v. Kursell. Verse von... München: Deutscher Volks-Verl.

Krótki zarys zagadnienia białoruskiego. (1928). Warszawa 31 I 1928 r. Referat opracowany na podstawie materiałów Oddział II Szt Gen. L.ew. 3 Tylko do użytku służbowego.

Lis-Błoński, S. (1929). Bałachowcy. Federacja, 1929(1-2), 29.

Lis-Błoński, S. (2013). Bałachowcy: Notatki oficera łącznikowego przy Ochotniczej Armii Sprzymierzonej z frontu wojny polsko-bolszewickiej 1920 roku (G. J. Pelica, Wstęp \& oprac.). Warszawa: Oficyna Wydawnicza Mireki.

Булак-Балахович, С. Н. (1923). Ген. Булак-Балахович о своем деле. W Архив гражданской войны (Cz. 1, ss. 153-157). Берлин: Русское творчество.

Шупа, С. (Red. \& Tłum.). (1998). Архівы Беларускай Народнай Рэспублікі [Archives of the Belarusian Democratic Republic] (T. 1, ks. 2). Мінск: Бел. ін-т навукі і мастацтва, Т-ва бел. пісьменства „Наша ніва”.

\section{Opracowania}

Berger, R. (2007). Bałachowicz a Żydzi. Akant: Miesięcznik Literacki, 10(11, dod. Świat Inflant, nr 11), 13-14.

Cabanowski, M. (1993). Generał Stanisław Bułak-Bałachowicz: Zapomniany bohater. Warszawa: „Mikromax”.

Cabanowski, M. (2000). Generał Stanisław Bułak-Bałachowicz: Zapomniany bohater (2. wyd. popr. i uzup.). Grodzisk Mazowiecki: Ośrodek Kultury.

Cabanowski, M. (2013). Generał Stanisław Bułak-Bałachowicz: Ostatni Kmicic II RP i wyklęci żołnierze wojny polsko-sowieckiej 1920 roku. Kraków: Oficyna Wydawnicza Mireki.

Cisek, J. (1993). Białoruskie oddziały gen. Stanisława Bułak-Bałachowicza w polityce Józefa Piłsudskiego w okresie wojny polsko-bolszewickiej (marzec-grudzień 1920 r.) (Rozprawa 
doktorska napisana w Instytucie Historii Uniwersytetu Wrocławskiego pod kierunkiem prof. Wojciecha Wrzesińskiego). Uniwersytet Wrocławski, Wrocław.

Engelstein, L. (2018). Russia in flames: War, revolution, civil war, 1914-1921. Oxford: Oxford University Press

Garlicki, A. (2003). „Dwójka” o Grupie gen. Bałachowicza. W M. Zgórniak, I. Stawowy-Kawka, \& W. Rojek (Red.), Państwa europejskie na drodze do niepodległości: W drugiej połowie XIX i XX wieku (ss. 283-300). Kraków: Tow. Wydawnicze „Historia Iagellonica”.

Gierowska-Kałłaur, J. (2003). Zarząd Cywilny Ziem Wschodnich. Warszawa: „Neriton”.

Gierowska-Kałłaur, J. (2005). Litwa Środkowa. Zeszyt Naukowy Muzeum Wojska, 2005(18), $117-125$.

Gierowska-Kałłaur, J. (2015a). „Kwestia białoruska” w Dzienniku Michała Romera: Na podstawie zapisów pomiędzy 25 marca 1918 a 6 marca 1920 roku (tom 24, 25 i 26 Diariusza). Przegląd Wschodni, 14(2(54)), 335-360.

Gierowska-Kałłaur, J. (2015b). Monarchiści i ich symulacje polityczne w maju lipcu 1920 r.: Memoriały płk. Maxa Bauera i gen. Wasilija Biskupskiego. Studia z Dziejów Rosji i Europy Środkowo-Wschodniej, 50(2), 31-54.

Gierowska-Kałłaur, J. (2017). Wizja polskiej polityki wobec Ziem Wschodnich w świetle Biuletynów Informacyjnych Straży Kresowej. W A. Dawid \& J. Lusek (Red.), Między mitem a rzeczywistością: Kresy Wschodnie w XIX i XX wieku. Bytom: Muzeum Górnośląskie.

Gomółka, K. (1989). Polska wobec oddziałów Stanisława Bułak-Bałachowicza w 1920 roku. Zeszyt Naukowy Muzeum Wojska, 1989(3), 100-106.

Grosfeld, L. (1965). Piłsudski i Sawinkow. W Studia historyczne: Księga jubileuszowa z okazji 70 rocznicy urodzin prof. dra Stanisława Arnolda (ss. 108-131). Warszawa: Książka i Wiedza.

i. (b.d.). Generał Bułak-Bałachowicz. Pobrano 20 maja 2016, z http://jpilsudski.org/artykuly -personalia-biogramy/generalicja-oficerowie-zolnierze/item/1810-general-bulak-balachowicz

Isakau, S. (Reżyser). (2009). Generał nieskończonej wojny [Film]. TVP/Belsat. Pobrano 20 maja 2016, z http://vod.tvp.pl/4284096/general-nieskonczonej-wojny

Iwanow, M. (2007). Stanisław Bułak-Bałachowicz i kwestia żydowska. Teki Biograficzne, 2007(2), 39-45,

Iwanow, M. (2010). Żydowskie wojsko Bułak-Bałachowicza. Przegląd Wschodni, 11(2), 365-379.

Jekabsons, E. (2011). Łotysze w oddziale Stanisława Bułak-Bałachowicza w latach 1918-1919 i pobyt oddziału na Łotwie w latach 1919-1920. Białoruskie Zeszyty Historyczne, 2011(35), 158-172.

Karpus, Z. (1990). Działalność gen. St. Bułak-Bałachowicza i jego oddziału w Polsce podczas wojny 1920. Zeszyt Naukowy Muzeum Wojska, 1990(4), 89-101.

Karpus, Z. (1999). Wschodni sojusznicy Polski w wojnie 1920 roku: Oddziały wojskowe ukraińskie, rosyjskie, kozackie i białoruskie w Polsce w latach 1919-1920. Toruń: Wydawnictwo Uniwersytetu Mikołaja Kopernika.

Karpus, Z., \& Łatyszonek, O. (1995). Życiorys gen. Stanisława Bułak-Bałachowicza. Białoruskie Zeszyty Historyczne (Białystok), 1995(2(4)), 160-169.

Koło tradycji wojskowej im. gen. Stanisława Bułak-Bałachowicza. (b.d.). Pobrano 20 maja 2016, z_http://web.archive.org/web/20090208101717/http:/raberg.webpark.pl/ 
Konstantynowicz, B. (b.d.). The Corps of Balachowicz. Pobrano 20 maja 2016, z http://konstantynowicz. info/Balachowicz/

Korbel, J. (2012, czerwiec 18). Krótka historia ostatniej puszczy Europy. Latarnia Morska. Pobrano 20 maja 2016, z http://www.latarnia-morska.eu/index.php?option=com_content\&view=ca tegory\&id=37\&Itemid $=62 \&$ limitstart $=80 \&$ lang $=\mathrm{pl}$

Leinwand, A. (1964). Polska a Denikin: Z dziejów stosunków między Polską a kontrrewolucją na południu Rosji w 1918-1920. W Z dziejów wojny i polityki: Księga pamiątkowa ku czci siedemdziesiątej rocznicy urodzin prof. dra Janusza Wolińskiego (ss. 33-38). Warszawa. (Zeszyt WEP, Seria historyczna, nr 11 (37)).

Łatyszonek, O. (1992). Spod czerwonej gwiazdy pod biały krzyż. Zeszyt Naukowy Muzeum Wojska w Białymstoku, 1992(6), 41-49.

Łatyszonek, O. (1995). Białoruskie formacje wojskowe 1917-1923. Białystok: Białoruskie Towarzystwo Historyczne.

Mackiewicz, J. (b.d.). Książka o niepokojących analogiach: „Pamiętniki” Wędziagolskiego. Pobrano 20 maja 2016, z http://www.jozefmackiewicz.com/teksty28.html (Pierwodruk „Wiadomości", 1972, nr 42 (1385)).

Paluszyński, T. (1992). Przejście oddziału generała Stanisława Bułak-Bałachowicza z Estonii do Polski (marzec 1920 roku). W J. Kiwerska, B. Koszel, \& D. Matelski (Red.), Polska i Europa w XIX-XX wieku: Studia historyczno-politologiczne (ss. 109-124). Poznań: „Arpress”.

Paluszyński, T. (2006). Stanisław Bułak-Bałachowicz w estońskiej wojnie narodowowyzwoleńczej w latach 1918-1919. Poznańskie Zeszyty Humanistyczne, 6, 81-99.

Patelski, M. (2006). Generał Stanisław Bułak-Bałachowicz - kontrowersje wokół postaci. W M. Iwanow (Red.), Białoruś trudna droga do demokracji. Wrocław: Wyd. Kolegium Europy Wschodniej im. Jana Nowaka-Jeziorańskiego.

Pelica, G. J. (2008). Konkretne czyny Stanisława Bułak-Bałachowicza. Akant, 11(4, dod. Świat Inflant, nr 4), 10.

Pelica, G. J. (2011). „Bałachowcy” Stanisława Lisa-Błońskiego jako przestrzeń refleksji i historyczny dokument. Lublin: Wydawnictwo Drukarnia Best Print.

Raport por. Błońskiego do szefa Oddz II Dowództwa 3.Armii z 30 VII 1920. (1990). W J. Cisek, Sąsiedzi wobec wojny 1920 roku (s. 124). Londyn: Polska Fundacja Kulturalna.

Simanski, P. (1931). Kampania białoruska Rosyjskiej Armii Ludowo-Ochotniczej gen. St. Bułak-Bałachowicza w 1920 r. Bellona, 1931(37), 196-232.

Skaradziński, B. (1999). Echo nad samą Wisłą. Więź, 1999(7), 116-120.

Smele, J. D. (2017). Historical dictionary of the Russian civil wars 1916-1926 (T. 1-2). Lanham, MD: Rowman \& Littlefiel.

Wędziagolski, K. (2007). Pamiętniki: Wojna i rewolucja, kontrrewolucja, bolszewicki przewrót, warszawski epilog (G. Eberhardt, Wstęp, posł. \& oprac. przypisów). Warszawa: Wydawnictwo Iskry.

Wilczyński, M. (2011, sierpień 17). Rycerze śmierci baćki Bałachowicza. Gazeta Polska (Warszawa), 2011(33), 16-17.

Zajko, A. (2008). Walki gen. Stanisława Bułak-Bałachowicza na białoruskim Polesiu. Podlaski Kwartalnik Kulturalny, 2008(3), 7-14. 
Zychowicz, P. (2011, sierpień 23). Zdradzeni przez Polskę. Rzeczpospolita, ss. P12-P13.

Булак-Балахович: Биографический указатель. (b.d.). Pobrano 2 listopada 2017, z http:// www.hrono.ru/biograf/bio_b/bulak_balahovich.php

Булак-Балахович Станислав Никодимович (1883-1940). (b.d.). Новый исторический вестник. Pobrano 2 listopada 2017, z http://www.nivestnik.ru/2002_2/8.shtml

Вашкевіч, А., Чарнякевіч, А., \& Юркевіч, Ю. (Tłum., przedmowa \& komentarze). (2014). Балахоўцы: Сведчанні. Дакументы. Даследаванні (2. wyd. uzup.). Смаленск: Інбелкульт.

Волков, С. В. (2010). Булак-Балахович. W Д. М. Володихин \& С. В. Волков (Red.), Гражданская война в России: Энциклопедия катастрофы (ss. 290-310). Москва: Сибирский цирюльник.

Заяц, Н. А., \& Кругликов, В. В. (2015). „Довести ненависть... к большевикам до озверения”: Полк С. Н. Балаховича в Лужском уезде в 1918 г. W А. В. Посадский (Red.), „Amaманщина" и „партизанщина” в Гражданской войне: Идеология, военное участие, кадры: Сборник статей и материалов. Москва: АИРО-ХХІ.

Клавинг, В. (2003). Гражданская война в России: Белье армии. Москва: АСТ. (Военноисторическая библиотека)

Кручинин, А. С. (2011). Генералы С. Н. и И. Н. Булак-Балаховичи. W А. С. Кручинин, Белое движение: Исторические портреты (ss. 1142-1201). Москва: Издательство Астрель.

Латышонак, А. (2009). Жаўнеры БНР. Беласток: Беларускае Гістарычнае Таварыства.

Милякова, Л. Б. (Red.). (2006). Книга погромов: Погромы на Украине, в Белоруссии и европейской части России в период Гражданской войны 1918-1922 г2.: Сборник документов. Москва: РОССПЭН.

Симонова, Т. (1997). Я зелёный генерал. Родина, 1997(11), 36-41. Pobrano 2 listopada 2017, $\mathrm{z}$ http://batko-bulak.livejournal.com/4376.html

Чернякевич, А. Н. (2015). „Балаховцы”: Послесловие: Отделы бывшей Добровольческой армии генерала С. Балаховича на территории Польши в 1921-1939 гг. W А. В. Посадский (Red.), „Атаманщина” и „партизанщзина” в Гражданской войне: Идеология, военное участие, кадрь:: Сборник статей и материалов. Москва: АИРО-ХХІ.

\section{Bibliography (Transliteration)}

\section{Printed sources}

Bulak-Balakhovich, S. N. (1923). Gen. Bulak-Balakhovich o svoem dele. In Arkhiv grazhdanskoı̆ voiny (Pt. 1, pp. 153-157). Berlin: Russkoe tvorchestvo.

Bułak-Bałachowicz, S. (1922). List otwarty gen. Bułak-Bałachowicza do Sejmu Ustawodawczego Rzeczypospolitej Polskiej. Warszawa: [Zakł. Graf. C.A.B.P.].

Eckart, D. (1921). Totengräber Rußlands. Zeichnungen von Otto v. Kursell. Verse von... München: Deutscher Volks-Verl.

Krótki zarys zagadnienia białoruskiego. (1928). Warszawa 31 I 1928 r. Referat opracowany na podstawie materiałów Oddział II Szt Gen. L.ew.3 Tylko do użytku służbowego. 
Lis-Błoński, S. (1929). Bałachowcy. Federacja, 1929(1-2), 29.

Lis-Błoński, S. (2013). Bałachowcy: Notatki oficera łącznikowego przy Ochotniczej Armii Sprzymierzonej z frontu wojny polsko-bolszewickiej 1920 roku (G. J. Pelica, Introduction \& Prep.). Warszawa: Oficyna Wydawnicza Mireki.

Shupa, S. (Ed. \& Trans.). (1998). Arkhivy Belaruskaĭ Narodnaĭ Réspubliki [Archives of the Belarusian Democratic Republic] (Vol. 1, Pt. 2). Minsk: Bel. in-t navuki i mastatstva, T-va bel. piśmenstva „Nasha niva”.

\section{Literature}

Berger, R. (2007). Bałachowicz a Żydzi. Akant: Miesięcznik Literacki, 10(11, Suppl. Świat Inflant, Nr 11), 13-14.

Bulak-Balakhovich: Biograficheskiř ukazatel'. (n.d.). Retrieved November 2, 2017, from http:// www.hrono.ru/biograf/bio_b/bulak_balahovich.php

Bulak-Balakhovich Stanislav Nikodimovich (1883-1940). (n.d.). Novyı̆ istoricheskĭ vestnik. Retrieved November 2, 2017, from http://www.nivestnik.ru/2002_2/8.shtml

Cabanowski, M. (1993). Generał Stanisław Bułak-Bałachowicz: Zapomniany bohater. Warszawa: „Mikromax”.

Cabanowski, M. (2000). Generał Stanisław Bułak-Bałachowicz: Zapomniany bohater (2nd ed., text rev.). Grodzisk Mazowiecki: Ośrodek Kultury.

Cabanowski, M. (2013). Generał Stanisław Bułak-Bałachowicz: Ostatni Kmicic II RP i wyklęci żołnierze wojny polsko-sowieckiej 1920 roku. Kraków: Oficyna Wydawnicza Mireki.

Cherniakevich, A. N. (2015). „Balakhovtsy”: Posleslovie: Otdely byvcheĭ Dobrovol’cheskoŭ armii generala S. Balakhovicha na territorii Pol’shi v 1921-1939 gg. In A. V. Posadskii (Ed.), „Atamanshchina” i „partizanshchina” v Grazhdanskoĭ voine: Ideologiia, voennoe uchastie, kadry: Sbornik stateŭ i materialov. Moskva: AIRO-XXI.

Cisek, J. (1993). Białoruskie oddziały gen. Stanisława Bułak-Bałachowicza w polityce Józefa Piłsudskiego w okresie wojny polsko-bolszewickiej (marzec-grudzień 1920 r.) (Rozprawa doktorska napisana w Instytucie Historii Uniwersytetu Wrocławskiego pod kierunkiem prof. Wojciecha Wrzesińskiego). Uniwersytet Wrocławski, Wrocław.

Engelstein, L. (2018). Russia in flames: War, revolution, civil war, 1914-1921. Oxford: Oxford University Press.

Garlicki, A. (2003). „Dwójka” o Grupie gen. Bałachowicza. In M. Zgórniak, I. Stawowy-Kawka, \& W. Rojek (Eds.), Państwa europejskie na drodze do niepodległości: W drugiej połowie XIX i XX wieku (pp. 283-300). Kraków: Tow. Wydawnicze „Historia Iagellonica”.

Gierowska-Kałłaur, J. (2003). Zarząd Cywilny Ziem Wschodnich. Warszawa: „Neriton”.

Gierowska-Kałłaur, J. (2005). Litwa Środkowa. Zeszyt Naukowy Muzeum Wojska, 2005(18), 117-125.

Gierowska-Kałłaur, J. (2015a). „Kwestia białoruska” w Dzienniku Michała Romera: Na podstawie zapisów pomiędzy 25 marca 1918 a 6 marca 1920 roku (tom 24, 25 i 26 Diariusza). Przegląd Wschodni, 14(2(54)), 335-360. 
Gierowska-Kałłaur, J. (2015b). Monarchiści i ich symulacje polityczne w maju lipcu 1920 r.: Memoriały płk. Maxa Bauera i gen. Wasilija Biskupskiego. Studia z Dziejów Rosji i Europy Środkowo-Wschodniej, 50(2), 31-54.

Gierowska-Kałłaur, J. (2017). Wizja polskiej polityki wobec Ziem Wschodnich w świetle Biuletynów Informacyjnych Straży Kresowej. In A. Dawid \& J. Lusek (Eds.), Między mitem a rzeczywistością: Kresy Wschodnie w XIX i XX wieku. Bytom: Muzeum Górnośląskie.

Gomółka, K. (1989). Polska wobec oddziałów Stanisława Bułak-Bałachowicza w 1920 roku. Zeszyt Naukowy Muzeum Wojska, 1989(3), 100-106.

Grosfeld, L. (1965). Piłsudski i Sawinkow. In Studia historyczne: Księga jubileuszowa z okazji 70 rocznicy urodzin prof. dra Stanisława Arnolda (pp. 108-131). Warszawa: Książka i Wiedza.

i. (n.d.). Generał Bułak-Bałachowicz. Retrieved May 20, 2016, from http://jpilsudski.org/ artykuly-personalia-biogramy/generalicja-oficerowie-zolnierze/item/1810-general-bulak -balachowicz

Isakau, S. (Director). (2009). Generał nieskończonej wojny [Film]. TVP/Belsat. Retrieved May 20, 2016, from http://vod.tvp.pl/4284096/general-nieskonczonej-wojny

Iwanow, M. (2007). Stanisław Bułak-Bałachowicz i kwestia żydowska. Teki Biograficzne, 2007(2), 39-45.

Iwanow, M. (2010). Żydowskie wojsko Bułak-Bałachowicza. Przegląd Wschodni, 11(2), 365-379.

Jekabsons, E. (2011). Łotysze w oddziale Stanisława Bułak-Bałachowicza w latach 1918-1919 i pobyt oddziału na Łotwie w latach 1919-1920. Białoruskie Zeszyty Historyczne, 2011(35), 158-172.

Karpus, Z. (1990). Działalność gen. St. Bułak-Bałachowicza i jego oddziału w Polsce podczas wojny 1920. Zeszyt Naukowy Muzeum Wojska, 1990(4), 89-101.

Karpus, Z. (1999). Wschodni sojusznicy Polski w wojnie 1920 roku: Oddziały wojskowe ukrainskie, rosyjskie, kozackie i białoruskie w Polsce w latach 1919-1920. Toruń: Wydawnictwo Uniwersytetu Mikołaja Kopernika.

Karpus, Z., \& Łatyszonek, O. (1995). Życiorys gen. Stanisława Bułak-Bałachowicza. Białoruskie Zeszyty Historyczne (Białystok), 1995(2(4)), 160-169.

Klaving, V. (2003). Grazhdanskaia voinna v Rossii: Belye armii. Moskva: AST. (Voenno-istoricheskaia biblioteka).

Koło tradycji wojskowej im. gen. Stanisława Bułak-Bałachowicza. (n.d.). Retrieved May 20, 2016, from http://web.archive.org/web/20090208101717/http:/raberg.webpark.pl/

Konstantynowicz, B. (n.d.). The Corps of Balachowicz. Retrieved May 20, 2016, from http:// konstantynowicz.info/Balachowicz/

Korbel, J. (2012, June 18). Krótka historia ostatniej puszczy Europy. Latarnia Morska. Retrieved May 20, 2016, from http://www.latarnia-morska.eu/index.php?option=com_content\&vi ew $=$ category\&id $=37 \&$ Itemid $=62 \&$ limitstart $=80 \&$ lang $=\mathrm{pl}$

Kruchinin, A. S. (2011). Generaly S. N. i I. N. Bulak-Balakhovichi. In A. S. Kruchinin, Beloe dvizhenie: Istoricheskie portrety (pp. 1142-1201). Moskva: Izdatel'stvo Astrel'.

Latyshonak, A. (2009). ZHaŭnery BNR. Belastok: Belaruskae Histarychnae Tavarystva.

Leinwand, A. (1964). Polska a Denikin: Z dziejów stosunków między Polską a kontrrewolucją na południu Rosji w 1918-1920. In Z dziejów wojny i polityki: Księga pamiątkowa ku czci 
siedemdziesiątej rocznicy urodzin prof. dra Janusza Wolińskiego (pp. 33-38). Warszawa. (Zeszyt WEP, Seria historyczna, nr 11 (37)).

Łatyszonek, O. (1992). Spod czerwonej gwiazdy pod biały krzyż. Zeszyt Naukowy Muzeum Wojska w Białymstoku, 1992(6), 41-49.

Łatyszonek, O. (1995). Białoruskie formacje wojskowe 1917-1923. Białystok: Białoruskie Towarzystwo Historyczne.

Mackiewicz, J. (n.d.). Książka o niepokojących analogiach: „Pamiętniki” Wędziagolskiego. Retrieved May 20, 2016, from http://www.jozefmackiewicz.com/teksty28.html (First printed „Wiadomości", 1972, Nr 42 (1385))

Miliakowa. L. B. (Ed.). (2006). Kniga pogromov: Pogromy na Ukraine, v Belorussii i evropeı̌skoŭ chasti Rossii v period Grazhdanskoĭ voiny 1918-1922 gg.: Sbornik dokumentov. Moskva: ROSSPE்N.

Paluszyński, T. (1992). Przejście oddziału generała Stanisława Bułak-Bałachowicza z Estonii do Polski (marzec 1920 roku). In J. Kiwerska, B. Koszel, \& D. Matelski (Eds.), Polska i Europa w XIX-XX wieku: Studia historyczno-politologiczne (pp. 109-124). Poznań: „Arpress”.

Paluszyński, T. (2006). Stanisław Bułak-Bałachowicz w estońskiej wojnie narodowowyzwoleńczej w latach 1918-1919. Poznańskie Zeszyty Humanistyczne, 6, 81-99.

Patelski, M. (2006). Generał Stanisław Bułak-Bałachowicz - kontrowersje wokół postaci. In M. Iwanow (Ed.), Białoruś trudna droga do demokracji. Wrocław: Wyd. Kolegium Europy Wschodniej im. Jana Nowaka-Jeziorańskiego.

Pelica, G. J. (2008). Konkretne czyny Stanisława Bułak-Bałachowicza. Akant, 11(4, Suppl. Świat Inflant, $\mathrm{Nr} 4), 10$.

Pelica, G. J. (2011). „Bałachowcy” Stanisława Lisa-Błońskiego jako przestrzeń refleksji i historyczny dokument. Lublin: Wydawnictwo Drukarnia Best Print.

Raport por. Błońskiego do szefa Oddz II Dowództwa 3.Armii z 30 VII 1920. (1990). In J. Cisek, Sąiedzi wobec wojny 1920 roku (p. 124). Londyn: Polska Fundacja Kulturalna.

Simanski, P. (1931). Kampania białoruska Rosyjskiej Armii Ludowo-Ochotniczej gen. St. Bułak-Bałachowicza w 1920 r. Bellona, 1931(37), 196-232.

Simonova, T. (1997). IA zelënyı̆ general. Rodina, 1997(11), 36-41. Retrieved November 2, 2017, from http://batko-bulak.livejournal.com/4376.html

Skaradziński, B. (1999). Echo nad samą Wisłą. Więź, 1999(7), 116-120.

Smele, J. D. (2017). Historical dictionary of the Russian civil wars 1916-1926 (Vols. 1-2). Lanham, MD: Rowman \& Littlefiel.

Vashkevich, A., Charniakevich, A., \& IUrkevich, I. (Trans., Foreword \& Commentary). (2014). Balakhoŭtsy: Svedchanni. Dakumenty. Dasledavanni (2 ${ }^{\text {nd }}$ ed., text rev.). Smalensk: Inbelkult.

Volkov, S. V. (2010). Bulak-Balakhovich. In D. M. Volodikhin \& S. V. Volkov (Eds.), Grazhdanskaia voina v Rossii: Éntsiklopediia katastrofy (pp. 290-310). Moskva: Sibirskiĭ tsiriulnik.

Wędziagolski, K. (2007). Pamiętniki: Wojna i rewolucja, kontrrewolucja, bolszewicki przewrót, warszawski epilog (G. Eberhardt, Foreword, Afterword \& Footnotes). Warszawa: Wydawnictwo Iskry.

Wilczyński, M. (2011, August 17). Rycerze śmierci baćki Bałachowicza. Gazeta Polska (Warszawa), 2011(33), 16-17. 
Zaiats, N. A., \& Kruglikow, V. V. (2015). „Dovesti nenavist' ... k bolshevikam do ozvereniia”: Polk S. N. Balakhovicha v Luzhskom uezde v 1918 g. In A. V. Posadskiǔ (Ed.), „Atamanshchina” $i$ „partizanshchina" $v$ Grazhdanskoĭ voinne: Ideologiia, voennoe uchastie, kadry: Sbornik stateŭ i materialov. Moskva: AIRO-XXI.

Zajko, A. (2008). Walki gen. Stanisława Bułak-Bałachowicza na białoruskim Polesiu. Podlaski Kwartalnik Kulturalny, 2008(3), 7-14.

Zychowicz, P. (2011, August 23). Zdradzeni przez Polskę. Rzeczpospolita, pp. P12-P13.

\section{Stanisław Bułak-Bałachowicz. Postać, która mogła połączyć narody byłego Wielkiego Księstwa Litewskiego, a jednak ich nie połączyła}

\section{Streszczenie}

Naczelnik Państwa Polskiego Józef Piłsudski w latach 1919-1920, konsekwentnie, w kilku etapach usiłował politycznie pozszywać organizm rozerwanego terytorium byłej Rzeczypospolitej Obojga Narodów.

Istotny wpływ na plany Józefa Piłsudskiego miało wydanie przez Ententę 6 marca 1920 r. tzw. Noty Milleranda, w której zabraniano Polsce przeprowadzenia na ziemiach byłego Wielkiego Księstwa Litewskiego samookreślenia zapowiedzianego w odezwie wileńskiej z kwietnia 1919 r. Do mieszkańców byłego W. Księstwa Litewskiego.

Wiosną 1920 r. narodowcy i Piłsudski „zamienili się” swoimi dotychczasowymi postulatami w sprawie zasięgu granicy wschodniej. Piłsudski chciał granicy z 1772 r., by mieć terytorium dla konstrukcji co najmniej państwa białoruskiego i ukraińskiego, natomiast narodowi demokraci dążyli z jednej strony do oszczędzenia Rosji, $\mathrm{z}$ drugiej - do pozyskania dla Polski takich obszarów, które będą dawały szanse na wchłonięcie przez ziemie etnicznie polskie.

Nikołaj Czajkowski i Borys Sawinkow złożyli wizytę w Belwederze jeszcze w połowie stycznia 1920 r. Piłsudski zdawał sobie sprawę, że Biali Rosjanie zechcą wykorzystać idealistę Sawinkowa do próby obciążenia Polski niemałymi kosztami konstruowania rosyjskiej armii na „uchodźctwie”.

Darzony powszechnym szacunkiem, posługujący się wszystkimi kresowymi językami, świetny żołnierz - Stanisław Bułak-Bałachowicz jeszcze jako podkomendny Mikołaja Judenicza, starał się o przemianowanie dowodzonego przez siebie oddziału na „Armię Ludową”, inaczej ujmując „Armię Terytorialną" lub „Krajową”.

Stanisława Bułak-Bałachowicza polityka jako narzędzie walki nigdy nie interesowała i nie znał się na niej zupełnie. Jesień 1919 r. to otwarcie „białoruskiej” karty w życiu generała. Bałachowicz nigdy nie ukrywał swej wybitnej niechęci do bolszewików, którzy stanowili pierwszoplanowe zagrożenie dla jego Kraju. 
Terytorialne rozumienie „białoruskości” powiązane z atawistycznym antybolszewizmem Bałachowicza wykorzystał Józef Piłsudski w swoim nowym projekcie politycznym. Piłsudski postanowił wykorzystać romantyczne marzenie Sawinkowa dla własnego celu. Rosyjski Komitet Polityczny, szable Bałachowicza i oświadczenia Wiaczesława Adamowicza (ojca) miały posłużyć do budowy - Białorusi dla Białorusinów. Nie „kowieńsko-berlińskiej” i nie „sowieckiej”. „Trzeciej Białorusi”. Białorusi przyjaznej Polsce.

Po 6 marca 1920 r. (tzw. Nota Milleranda), w wyniku rozmów z Sawinkowem, budowniczym „Trzeciej Rosji”, Piłsudski zaangażował się we wspieranie (również finansowe) Rosyjskiego Komitetu Politycznego.

Na podstawie umowy Polskiego Naczelnego Dowództwa z B. W. Sawinkowem wszystkie formacje rosyjskie na terytorium Rzeczpospolitej Polskiej zostały podporządkowane politycznie i finansowo (ale nie militarnie) B. Sawinkowowi. 27 sierpnia 1920 r. z rozkazu Naczelnego Dowództwa Bałachowicz zawarł z Sawinkowem tajną umowę. $\mathrm{W}$ walce $\mathrm{z}$ bolszewikami oddział generała Bułak-Bałachowicza występować miał pod jednolitymi hasłami z oddziałami rosyjskimi na terytorium polskim na czele i obaj z Sawinkowem dążyć mieli do zwołania w przyszłości zgromadzenia ustawodawczego, ziemi dla ludu, demokracji i utworzenia Związku Narodów (federacji).

Uwaga 1. Problem dalszej zależności strategicznej generała Bałachowicza i innych oddziałów w wypadku jednolitego dowództwa oddziałów rosyjskich formowanych na terenie Polski i poza nim miał być wyjaśniony wówczas, gdyby taka sytuacja powstała.

Uwaga 2. W przypadku posunięcia się oddziału Bułak-Bałachowicza „w głąb terytorium rosyjskiego" miał być przy nim (przy Bałachowiczu) zorganizowany samorząd lokalny i zarząd administracyjny. Właśnie w ten sposób Bułak-Bałachowicz miał być wykonawcą pierwszego etapu kolejnego „pomysłu” J. Piłsudskiego „na Białoruś".

Dnia 12 października 1920 r. warszawski Białoruski Komitet Polityczny (Paweł Aleksiuk, Wiaczesław Adamowicz ojciec i inni) doszedł do porozumienia z generałem Bałachowiczem. Białoruski Komitet Polityczny zobowiązał się przeprowadzić akcję werbunkową do mającej powstać Armii Białoruskiej pod dowództwem Bałachowicza, ten zaś miał Białoruskiemu Komitetowi Politycznemu oddawać władzę cywilną na zajmowanych stopniowo terenach etnograficznie białoruskich.

Dnia 2 listopada 1920 r. miała miejsce narada polityków polskich i białoruskich. Celem „Akcji Słuckiej” miało być osiągnięcie niepodległości Białorusi. Niepodzielność Białorusi miała być osiągnięta w drodze federacji z Polską i poprzez ściślejszy związek z Litwą Środkową, która jeszcze przeżywała swoje pierwsze $72 \mathrm{dni}$. Miał być zwołany Sejm Ustawodawczy Białej Rusi. Prawowity, a nie samozwańczy rząd w ustalonym składzie 50\% Białorusinów, 40\% Polaków, 10\% Żydów powołany miał być przez Radę Najwyższą. Jednym słowem ta projektowana państwowość „w planach Piłsudskiego według źródeł białoruskich” miała być niewątpliwie „białoruska”. 
Warunkami białoruskiego sukcesu miały być: brak istnienia wewnętrznych tarć wśród Białorusinów, oparcie władzy na samorządach oraz współpracy liderów Białorusi z Bułak-Bałachowiczem. Żaden z nich nie został przez Białorusinów spełniony.

Nie wszyscy Polacy mieli świadomość tego, co jest stawką w toczącej się grze. Niezrozumienie wykazywali również oficerowie polskiego Sztabu.

Lis-Błoński wyraźnie pisze o „poważnych nieporozumieniach”, do których dochodziło między nim a Bałachowiczem w okresie poprzedzającym deklarację mozyrską. Oddziały grupy Bałachowicza złożone z samych Białorusinów uważały, że teren, który mają pod kontrolą, jest integralną częścią Republiki Białoruskiej. I te oddziały zaczęły również, gdzie tylko się dało, urządzać wioski i gminy na swoją modłę, inaczej - na „rosyjski sposób”.

Tymczasem 11 listopada 1920 r. w konsekwencji zawartej w Kownie przez białoruski rząd Wacława Łastowskiego umowy z władzami niechętnej Polsce Litwy, o współpracy polityczno-ekonomicznej, Łastowski, w imieniu Białoruskiej Republiki Ludowej (dalej BRL) zrzekł się na rzecz Litwinów roszczeń Białorusinów do Wilna jako do swej stolicy. Zadeklarowano wspólny litewsko-białoruski front przeciw Polakom.

Jeszcze 14 listopada $1920 \mathrm{r}$. Zjazd Białoruski Słuczczyzny podjął uchwałę o ostrzu antysowieckim, wzywając do utworzenia wolnej Białorusi w granicach etnograficznych oraz, jednocześnie, do serdecznego powitania „naszej siostry Polski”.

Dnia 15 listopada 1920 r. do Słucka przybyli osobiści delegaci Bałachowicza (m.in. jego rodzony brat), niestety, rząd dusz przechwycili eserzy (SR, socjalrewolucjoniści), zorientowani na konsekwentnie niechętną Polsce BRL w Kownie. Probałachowiczowsko i propolsko nastawiona trójka organizatorów Zjazdu Białoruskiego (Arseniusz Pawlukiewicz, Anton Baczko i Jan Macelli) została zepchnięta do defensywy. Białoruska Rada Najwyższa w Warszawie odmówiła - pomimo zabiegów generała - jakichkolwiek rozmów z Bałachowiczem. W Słucku zaś snuć zaczęto plany jak „wyrwać” formujące się pod Bałachowiczem oddziały spod jego wpływu.

Dnia 16 listopada 1920 r. w Mozyrzu Stanisław Bułak-Bałachowicz ogłosił powstanie Białoruskiej Republiki Ludowej (bis) z Wiaczesławem Adamowiczem seniorem (uczestnikiem Pierwszego Zjazdu Wszechbiałoruskiego) jako premierem na czele, a sam ogłosił się Naczelnym Wodzem Białorusi. Słucka Rada Białoruska negatywnie odpowiedziała na tę ofertę, odrzucając współpracę z Bałachowiczem i zdecydowanie deklarując podporządkowanie antypolsko nastawionemu rządowi BRL w Kownie.

Niezwykle charakterystyczna była reakcja Borysa Sawinkowa na wieść o treści mozyrskiej deklaracji „Baćki”, zgodnej przecież z punktami umowy sierpniowej, którą sam zawarł z Bałachowiczem. W pełnym emocji obszernym liście Bałachowicza do Borysa Sawinkowa czytamy, że Sawinkow miał Bałachowiczowi wykrzyczeć 16 listopada w Mozyrzu w twarz - „Gdybym był wiedzial, że o Białą Ruś chodzi, nigdy w życiu bym nie poszed!!". 
Sądząc z emocjonalnego listu Bułak-Bałachowicza do Sawinkowa, ten ostatni dał się podejść Piłsudskiemu, przekonany, że jedynym celem Naczelnika Państwa Polskiego jest - zgodnie z oczekiwaniami Wrangla - antybolszewicka krucjata i prewencyjna budowa Rosji demokratycznej. Sawinkow dopiero w Mozyrzu zrozumiał, że o mały włos nie został wykorzystany. Lis-Błoński winą za niepowodzenie akcji mozyrskiej jednoznacznie obwiniał Sawinkowa. Sawinkow oczywiście nigdy nie zamierzał fragmentaryzować przyszłej „Trzeciej Rosji” przez budowę jakiejś Białorusi. Jednak to nie on był winien. Oferta Bułak-Bałachowicza została odrzucona pomimo wewnętrznej silnej opozycji - przez samych Białorusinów.

1. Bułak-Bałachowicz mirem cieszył się wśród niesformowanego politycznie i państwowo ludu swoich krajan, „krajowców”, a nie wśród - nazwijmy rzecz po imieniu - elitarnej grupy zawodowych białoruskich polityków. Ci w Kownie nie znali, bo znać nie mogli, żadnego oświadczenia politycznego Bułak-Bałachowicza przed Mozyrzem. A to oświadczenie mozyrskie stanowiło konkurencję dla ich istnienia.

2. Wspierana po rozłamie 13 grudnia 1919 r. przez Belweder białoruska Rada Najwyższa nie stanęła po stronie Bałachowicza.

3. Podpisanie porozumienia 16 listopada 1920 r. w Mozyrzu między Rosyjskim Politycznym Komitetem a Komitetem Białoruskim Wiaczesława A. Adamowicza było po prostu ruchem fasadowym, wymuszonym na Rosjanach okolicznościami. Sawinkow, ze względu na swoją własną sytuację na białorosyjskiej scenie politycznej, absolutnie nie zamierzał w 1920 r. budować państwa białoruskiego. Więcej, to on w kwietniu 1921 r. rozpętał na gruncie międzynarodowym akcję mającą na celu obciążenie oddziałów Bałachowicza odpowiedzialnością za wszystkie karygodne pogromy na Żydach, które miały w tych czasach miejsce - zaznaczmy to wyraźnie od Bałtyku do Morza Czarnego.

4. Pogrobowcy bałachowiczowskiego etapu probiałoruskiej polityki Piłsudskiego, sygnatariusze fasadowego rosyjsko-białoruskiego porozumienia, zorientowani na Polskę Wiaczesław Adamowicz i Paweł Aleksiuk - w wyniku zakulisowych intryg białorusko-białoruskich - znajdowali się na marginesie białoruskiej sceny politycznej.

5. Do anulowania fasadowego porozumienia Rosyjskiego Komitetu Politycznego, (który formalnie przemianowany został na Rosyjski Ewakuacyjny Komitet) i Białoruskiej Republiki Ludowej doszło w czerwcu 1921 r. w trakcie Narady Przedstawicieli Rosyjskiego Politycznego Ewakuacyjnego Komitetu w Polsce i Przedstawiciela Białoruskiego Wojskowo-Politycznego Centrum. Posunięcie to strona rosyjska osłodziła Białorusinom opracowaniem „Prognozy politycznej dla Białorusi” jako dla podmiotu politycznego „nierozrywnego”, prognozy sporządzonej przez prawą rękę Sawinkowa i agenta Czeka w jednej osobie A. A. Dikgof-Derentala, który występował wówczas w imieniu Rosyjskiego Politycznego Ewakuacyjnego Komitetu w Polsce.

Jest istotnym pytaniem badawczym to, czy w ogóle Stanisław Bułak-Bałachowicz zdawał sobie w 1920 r. sprawę z planowanej swojej „pozycji” w nowej kombinacji 
politycznej Piłsudskiego? Być może - niedoszły Naczelny Wódz Armii Białoruskiej wyparł ze swej pamięci afront, jaki go spotkał w Mozyrzu ze strony swoich krajan? Hipotezę tę poprzeć mogłaby nagła zmiana orientacji Bałachowicza - to pod wpływem fiaska Mozyrza „stał się” tzw. stuprocentowym Polakiem. W zmienionych po traktacie ryskim realiach warszawskich salonów i kuluarów tylko jako Polak miał szanse zadbać o status i godziwe zaopatrzenie swoich żołnierzy i ich rodzin po wojnie. A status tych żołnierzy w Polsce powojennej, w konsekwencji karkołomnego, zaplanowanego przez Piłsudskiego, rozdarcia służbowej zależności, był bardzo niekorzystny.

Słowa kluczowe: Bułak-Bałachowicz; Piłsudski; Sawinkow; wojna polsko-bolszewicka; Białoruś

\title{
Stanisław Bułak-Bałachowicz. He who could have united the nations of the former Grand Duchy of Lithuania, yet did not
}

\begin{abstract}
In 1919-1920, Józef Piłsudski, Polish Chief of State, made consistent political attempts at patching up the torn-apart territories of the former Polish-Lithuanian Commonwealth.

One significant impact on Piłsudski's plan was the adoption by the Allies, on the $6^{\text {th }}$ of March 1920, of the so-called Millerand's note, which prohibited Poland from carrying out a self-proclamatory referendum in the area of the former Grand Duchy of Lithuania, announced in April 1919 in Vilnius and addressed to residents of the former Grand Duchy of Lithuania.

In the spring of 1920, the nationalist side and Piłsudski had "swapped" their demands in regard to the eastern border so far. Piłsudski was believed to expect the return of the border from 1772, in order to retain territory for the establishment of at least both a Belarusian and Ukrainian state, while the National Democrats sought to spare Russia, and obtain areas which would give a chance to absorb ethnically Polish lands into the motherland.

Nikolai Tchaikovsky and Boris Savinkov paid a visit to the Belweder Palace already in mid-January 1920. Piłsudski was well aware that the White Russians would want to use the idealist Savinkov to attempt to charge the Polish side with inconsiderable costs (both financial and moral) of the formation of the Russian Army in exile.

General Stanisław Bułak-Bałachowicz, revered, fluent in all borderland languages, an excellent soldier, when he was a subordinate of Nikolai Yudenich had tried
\end{abstract}


to rename the unit under his command to the "People's Army", or in other words, the Territorial or National Army.

Stanisław Bułak-Bałachowicz never saw politics as a weapon; he never paid great interest nor had a greater knowledge of it. The autumn of 1919 marks the beginning of the "Belarusian" episode in his life. He never tried to hide his outstanding aversion to the Bolsheviks, who constituted a foreground threat to his country. In the early spring of 1920, Bałachowicz knew the BPR's "potential" from the inside... and thus he chose an ally that seemed a promise of success.

The territorial understanding of "Belarusness", in conjunction with the nearly atavistic anti-bolshevism of Bałachowicz, were a great asset in Józef Piłsudski's new political combination. Piłsudski decided to benefit from Savinkov's idealistic approach for his own purpose. The Russian Political Committee, Bałachowicz's troops and the statements of Vyacheslav Adamovich (father) were to support the establishment of a Belarus for Belarusians. Not under Kaunas and Berlin, nor a Soviet one. A "Third Belarus". A Belarus friendly towards Poland.

Following discussions with Savinkov, the builder of the "Third Russia", Piłsudski engaged himself after $6^{\text {th }}$ of March 1920 in supporting (inter alia financially) the Russian Political Committee.

Based on the agreement of the Polish Supreme Command with B. V. Savinkov, all Russian formations on the Polish territory were politically subordinated to Savinkov, and the amounts paid by the Polish Government since $1^{\text {st }}$ of March 1920 were recognized as Russia's sovereign debt to the Polish Republic.

In August 1920, on the orders of the Supreme Command, Bałachowicz entered a secret agreement with Savinkov. They both were also to seek convening the Constituent Assembly, providing land for the people and democracy, and to create a Union of Nations (i.e., a federation).

Note 1. The issue of further strategic dependence of General Bałachowicz and other unit in the event of a single command of Russian troops formed on Polish territory and abroad was to be settled only when such a situation would actually arise.

Note 2. In the event of Bałachowicz's unit succeeding "deeper into Russian territory", the local government and the administrative board were to be founded on his authority. This is how Bułak-Bałachowicz was to become the executor of the first phase of Piłsudski's new "concept for Belarus".

On $12^{\text {th }}$ of October 1920 the Warsaw-based "Belarusian Political Committee" (Pavel Aleksiuk, Vyacheslav Adamovich father and others) reached an agreement with General Bałachowicz. The Belarusian Political Committee undertook to carry out the recruitment for the Belarusian army to be formed under Bałachowicz's leadership, while the latter would cede civil authority in the gradually conquered, ethnically Belarusian territories to the Belarusian Political Committee.

On $2^{\text {nd }}$ of November 1920, a meeting of Polish and Belarusian politicians took place. The aim of the Slutsk Action was to achieve independence for Belarus. The indivisibility of 
Belarus was to be achieved by means of a federation with Poland and a closer cooperation with Central Lithuania, which was still going through its first 72 days. The Legislative Sejm of White Ruthenia was to be convened. A legitimate, i.e. not a self-proclaimed government - in a fixed composition of $50 \%$ of Belarusians, $40 \%$ of Poles and $10 \%$ of Jews - was to be appointed by the Supreme Council. In short, this planned statehood in "Piłsudski's plans according to Belarusian sources" was to be undoubtedly "Belarusian".

The conditions for Belarusian success were to be: a lack of internal frictions among the Belarusians, the foundation of authority on local governments and cooperation with Bułak-Bałachowicz. None of these was satisfied by the Belarusians.

Not all Poles were aware of what was at stake. Even Polish General Staff officers showed confusion. Lis Błoński clearly writes about "serious misunderstandings" which occurred between him and Bałachowicz in the period preceding the Mozyr declaration (November 1920). Those of Bałachowicz's units that were composed of Belarusians only believed that the area which fell under their control was an integral part of the Republic of Belarus. These units also began to rearrange each possible village and municipality in their own way: the "Russian way".

Meanwhile, on $11^{\text {th }}$ of November 1920, the Belarusian government of Vaclav Lastovski reached an agreement in Kaunas with the Lithuanian authorities reluctant towards Poland on political and economic cooperation. Lastovski, on behalf of the Belarusian People's Republic, withdrew the claims of Belarusians to Vilnius as their capital in favor of the Lithuanians. A joint Lithuanian-Belarusian front against Poland was declared.

On the $14^{\text {th }}$ of November 1920, the Belarusian Congress of Sluchchyna adopted an anti-Soviet resolution calling for the creation of a free Belarus within its ethnographic area and, at the same time, showing a cordial welcome to "our sister Poland".

On the $15^{\text {th }}$ personal delegates of Bałachowicz (including his brother) arrived in Slutsk, however, the SRs, oriented towards the BPR in Kaunas, consistently reluctant Poland, had already taken over spiritual leadership. The three pro-Bałachowicz and pro-Polish organizers of this congress (Arseniusz Pawlukiewicz, Anton Baczko and Jan Macelli) were put on the defensive.

The Belarusian Supreme Council (Rada), while supported by Piłsudski, refused any talks with Bałachowicz, despite the latter's efforts. At the same time, delegates in Slutsk were already planning on how to "tear away" the troops forming under Bałachowicz from his influence.

On the $16^{\text {th }}$ of November 1920, Stanisław Bułak-Bałachowicz announced in Mozyr the creation of the Belarusian People's Republic (bis) headed by Vyacheslav Adamowicz (father), a participant of the First All-Belarusian Congress, as Prime Minister, while he proclaimed himself Commander-in-Chief of Belarus. 
The Congress of Sluchchyna responded negatively to this offer by rejecting cooperation with Bałachowicz and declaring their effective subordination to the consistently anti-Polish BPR government in Kaunas.

Extremely characteristic of Boris Savinkov was his reaction to the contents of the Mozyr declaration, even though it was consistent with the agreement he had reached with Bałachowicz in August. In Bałachowicz's long, emotional letter to Boris Savinkov, we find that, back on the $16^{\text {th }}$ of November in Mozyr, Savinkov had shouted in his face: "If I had known it was all about White Ruthenia, never in my life would I have gone!"

Judging from Bułak-Bałachowicz's emotional letter to Savinkov, the latter had been taken in by Piłsudski, convinced that the sole objective of the Polish Head of State was, as expected by Wrangel, an anti-Bolshevik crusade and preventive establishment of a democratic Russia. It was only in Mozyr that Savinkov realized that he has almost been taken advantage of.

Lis-Błoński expressly blamed Savinkov for the failure of the Mozyr effort. Savinkov, of course, never intended to disintegrate the future Third Russia through the establishment of some independent Belarus. However, it was not his fault. Bułak-Bałachowicz's was rejected, despite strong internal opposition, by the Belarusians themselves. Why did it fail? Reasons were manyfold.

1. Bułak-Bałachowicz enjoyed authority among the local crowd of his politically and nationally unstructured countrymen, and not, let us face it, the elite group of professional Belarusian politicians. Those in Kaunas had no knowledge, as they could not have any, of Bułak-Bałachowicz's political statements before Mozyr. While the one from Mozyr constituted a threat to their political and physical existence.

2. The Supreme Council, backed by Piłsudski since the $13^{\text {th }}$ of December 1919, refused to take Bałachowicz's side.

3. The signing of the agreement between the Russian Political Committee and the Belarusian Committee of Vyacheslav A. Adamovich on the $16^{\text {th }}$ of November 1920 in Mozyr was just a symbolic move forced on the Russians by the circumstances. Savinkov, given his own situation on the Belarusian political scene, in 1920 had absolutely no intention of establishing a Belarusian state. Moreover, it was him who, in April 1921, did unleash on international level a campaign of blaming Bałachowicz for all the shameful anti-Jewish pogroms that took place from the Baltic to the Black Sea in that period.

4. As a result of backroom intra-Belarusian intrigues, the executors of Piłsudski's pro-Belarusian policies based around Bałachowicz and signatories of the Russian-Belarusian agreement, the pro-Polish activists Vyacheslav Adamovich and Pavel Aleksiuk found themselves on the margin of the Belarusian political scene.

The breaking of the illusory agreement between the Russian Evacuation Committee and the Belarusian People's Republic occurred in June 1921 in the course of 
deliberations of the Representatives of Russian Political Evacuation Committee in Poland and a representative of the Belarusian Military and Political Centre. The Russian side alleviated the effects of this move by elaborating a "Political forecast for Belarus" as an undivisable political entity, drawn up by Savinkov's aide and Cheka agent A. A. Dikgof-Derental who acted on behalf of the Russian Political Evacuation Committee in Poland.

One important question is whether Stanisław Bułak-Bałachowicz was actually aware in 1920 of his "position" in Piłsudski's planned new political combination. Could it be that the would-be Commander-in-Chief of the Belarusian Army had repressed the memory of the affront he met with in Mozyr from his countrymen?

This hypothesis could be supported by the sudden change in Bałachowicz's orientation who, following his failure in Mozyr, "became" $100 \%$ Polish. In the new realities of Warsaw's political spheres and backrooms after the Treaty of Riga, Bałachowicz only as a Pole could guarantee the status and decent supplies for his troops and their families after the war. The end justifies the means. Especially that, in consequence of the sudden reshuffles in the spheres of influence, the status of these soldiers was disadvantageous.

Keywords: Bułak-Bałachowicz; Piłsudski; Sawinkow; Polish-Soviet war; Belarus

Dr. hab. Joanna Gierowska-Kałłaur, Professor in Tadeusz Manteuffel Institute of History, Polish Academy of Sciences in Warsaw (Section of History of Eastern Europe and Studies on 19/20 th Century Empires); Ph.D. dissertation in 2003, habilitation in 2013. Lecturer at the University of Warsaw (since 2004, specialisation: history of the former Polish-Lithuanian Commonwealth in the $19^{\text {th }}$ and $20^{\text {th }}$ centuries, Józef Piłsudski's eastern policies, methodology of historical research); Author of three books and co-author of five, author of 90 scholarly articles, essays and reviews. She has conducted extensive research on the history of Polish parliamentarism; political history of the Second Polish Republic; Polish eastern policies; political, social, cultural, ethnic, national and religious changes in the territories of the former Grand Duchy of Lithuania in the $20^{\text {th }}$ century; documentation of the political and social history of the inhabitants of the former Grand Duchy of Lithuania in the first decades of the $20^{\text {th }}$ century; history of Estonia, Latvia, Lithuania, Belarus and Ukraine in the $20^{\text {th }}$ century. Her works are based on hitherto unknown sources uncovered during numerous inquiries in the archives of Warsaw, Kraków, Wrocław, Vilnius, Minsk, Moscow, Petersburg, Odessa, Prague, and London. Most often published in the periodical Studia z Dziejów Rosji i Europy [Studies into the History of Russia and 
Central-Eastern Europe]. Member of the Academic Council of the periodical Альманах североевропейских и балтийских исследований [Nordic and Baltic Studies Review] since 2015; Member of the Central-Eastern Academic Council of the periodical Studia Białorutenistyczne [Belarusian Studies] since 2015; regular reviewer for the periodical Studia Polsko-Wschodnie [Polish-Eastern Studies] since 2015. Secretary of editorial staff of the periodical Przeglad Wschodni [Eastern Review], 2004-2006.

Bibliography (selection): Straż Kresowa a Zarzad Cywilny Ziem Wschodnich: wspótdziałanie czy rywalizacja? [The Borderland Guard and the Civilian Board of the Eastern Territories. Cooperation or rivalry?], Warszawa (Warsaw) 1999, 129 pp.; Zarząd Cywilny Ziem Wschodnich (19 lutego 1919 - 9 września 1920) [The Civilian Board of the Eastern Territories (19 February 1919 - 9 September 1920)], Warszawa (Warsaw) 2003, 447 pp.; Raporty Straży Kresowej 1919-1920. Ziem Północno-Wschodnich opisanie [Reports of the Borderland Guard 1919-1920. Description of the North-Eastern lands], in: O Niepodległa i granice, Vol. 7, Warszawa-Pułtusk (Warsaw-Pułtusk), 2011, 1173 pp.

Correspondence: Joanna Gierowska-Kałłaur, The Tadeusz Manteuffel Institute of History, Polish Academy of Sciences, Warsaw, e-mail: j.gierowska-kallaur@uw.edu.pl

Support of the work: This work was supported by a core funding for statutory activities from the Polish Ministry of Science and Higher Education.

Competing interests: No competing interests have been declared. (A fragment of the study will be used by the author in her work Józef Piłsudski wobec kwestii białoruskiej [Józef Piłsudski and the Belarusian issue]). 